[American Journal of Science, Vol. 307, January, 2007, P. 63-118, DOI 10.2475/01.2007.04]

\title{
AGES AND ORIGINS OF ROGKS OF THE KILLINGWORTH DOME, SOUTH-GENTRAL CONNECTICUT: IMPLICATIONS FOR THE TECTONIC EVOLUTION OF SOUTHERN NEW ENGLAND
}

\author{
JOHN N. ALEINIKOFF*, ROBERT P. WINTSCH**, RICHARD P. TOLLO***, \\ DANIEL M. UNRUH*, C. MARK FANNING****, and MARK D. SCHMITZ ${ }^{\ddagger}$
}

\begin{abstract}
The Killingworth dome of south-central Connecticut occurs at the southern end of the Bronson Hill belt. It is composed of tonalitic and trondhjemitic orthogneisses (Killingworth complex) and bimodal metavolcanic rocks (Middletown complex) that display calc-alkaline affinities. Orthogneisses of the Killingworth complex (Boulder Lake gneiss, $456 \pm 6 \mathrm{Ma}$; Pond Meadow gneiss, $\sim 460 \mathrm{Ma}$ ) were emplaced at about the same time as eruption and deposition of volcanic-sedimentary rocks of the Middletown complex (Middletown Formation, $449 \pm 4 \mathrm{Ma}$; Higganum gneiss, $459 \pm 4 \mathrm{Ma})$. Hidden Lake gneiss $(339 \pm 3 \mathrm{Ma})$ occurs as a pluton in the core of the Killingworth dome, and, on the basis of geochemical and isotopic data, is included in the Killingworth complex.

$\mathrm{Pb}$ and $\mathrm{Nd}$ isotopic data suggest that the Pond Meadow, Boulder Lake, and Hidden Lake gneisses (Killingworth complex) resulted from mixing of Neoproterozoic Gander terrane sources (high ${ }^{207} \mathrm{~Pb} /{ }^{204} \mathrm{~Pb}$ and intermediate $\varepsilon_{\mathrm{Nd}}$ ) and less radiogenic (low ${ }^{207} \mathrm{~Pb} /{ }^{204} \mathrm{~Pb}$ and low $\varepsilon_{\mathrm{Nd}}$ ) components, whereas Middletown Formation and Higganum gneiss (Middletown complex) were derived from mixtures of Gander basement and primitive (low ${ }^{207} \mathrm{~Pb} /{ }^{204} \mathrm{~Pb}$ and high $\left.\varepsilon_{\mathrm{Nd}}\right)$ sources. The less radiogenic component for the Killingworth complex is similar in isotopic composition to material from Laurentian (Grenville) crust. However, because published paleomagnetic and paleontologic data indicate that the Gander terrane is peri-Gondwanan in origin, the isotopic signature of Killingworth complex rocks probably was derived from Gander basement that contained detritus from non-Laurentian sources such as Amazonia, Baltica, or Oaxaquia. We suggest that the Killingworth complex formed above an east-dipping subduction zone on the west margin of the Gander terrane, whereas the Middletown complex formed to the east in a back-arc rift environment.

Subsequent shortening, associated with the assembly of Pangea in the Carboniferous, resulted in Gander cover terranes over the Avalon terrane in the west; and in the Middletown complex over the Killingworth complex in the east. Despite similarities of emplacement age, structural setting, and geographic continuity of the Killingworth dome with Oliverian domes in central and northern New England, new and published isotopic data suggest that the Killingworth and Middletown complexes were derived from Gander crust, and are not part of the Bronson Hill arc that was derived from Laurentian crust. The trace of the Ordovician Iapetan suture (the Red Indian line) between rocks of Laurentian and Ganderian origin probably extends from Southwestern New Hampshire west of the Pelham dome of northcentral Massachusetts and is coverd by Mesozoic rocks of the Hartford basin.
\end{abstract}

INTRODUCTION

Tectonic models for the origins of terranes in New England have evolved to increasing complexity with the confluence of multiple techniques, including mapping (structure and stratigraphy), igneous and metamorphic petrology, geochemistry, geochronology, geophysics, and isotope geology (Tucker and others, 2001; Moench and Aleinikoff, 2003). These methods have facilitated correlation of high-grade, highly attenuated Paleozoic and Neoproterozoic rocks in southern New England with lower

*U.S. Geological Survey, Mail Stop 963, Federal Center, Denver, Colorado 80225; jaleinikoff@usgs.gov ***Department Geological Sciences, Indiana University, Bloomington, Indiana 47405

*** Department of Geology, George Washington University, Washington, DC 20052

*****esearch School of Earth Sciences, Australian National University, Canberra ACT 0200, Australia

${ }^{\ddagger}$ Department of Geosciences, Boise State University, Boise, Idaho 83725 


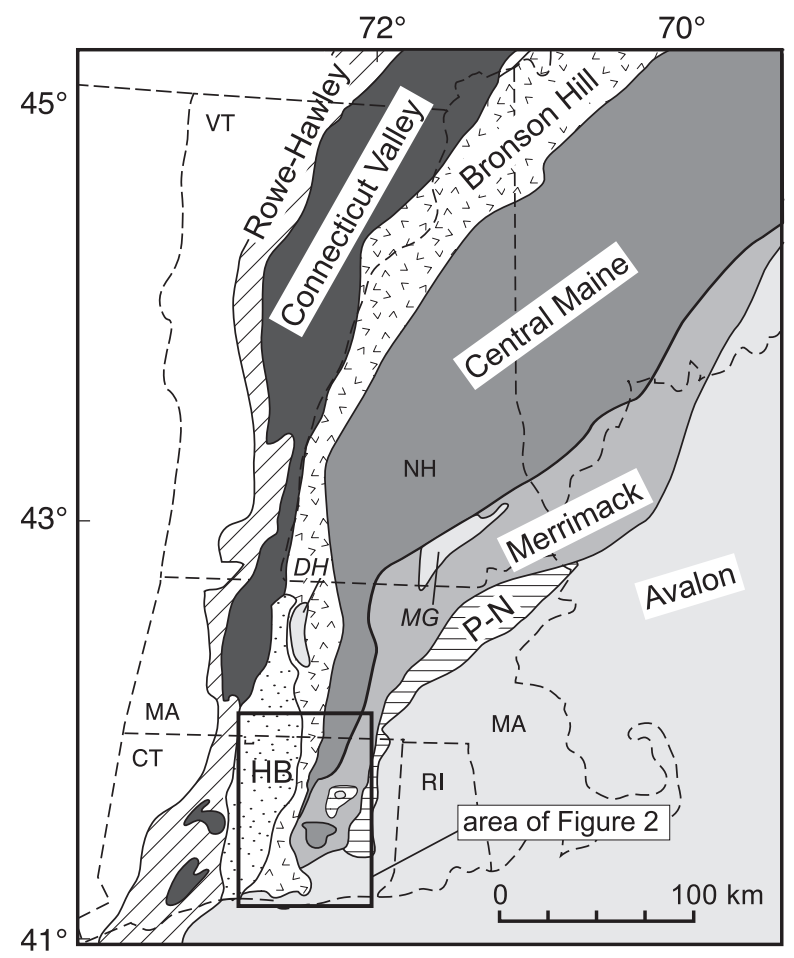

Fig. 1. Map of terranes of New England, modified from Hibbard and others (2006). Abbreviations: HB (Hartford basin), DH (Dry Hill Gneiss of Pelham dome), MG (Massabesic Gneiss), P-N (Putnam-Nashoba).

grade correlatives in northern New England and Maritime Canada (Tremblay and Pinet, 2005; Zagorevski and others, 2006; Wintsch and others, 2007). New interpretations have led to refinement of regional-scale terrane definitions and boundaries. It is now clear that several terranes (Bronson Hill, Central Maine, Merrimack, PutnamNashoba, Gander, and Avalon) of distinctly different origins are juxtaposed in a relatively small area of south-central New England (fig. 1). The Killingworth dome is shown here to be crucial to unraveling the accretionary history of terranes to the Laurentian margin in the middle and late Paleozoic.

The Killingworth dome (fig. 2) is the southernmost of a series of domes that expose largely calc-alkaline rocks along a narrow belt in central New England. The dome was previously interpreted as consisting of a homogeneous body of tonalitic rock (Rodgers, 1985). Webster and Wintsch (1987) used whole-rock major and trace element geochemistry to redefine units within the dome, including both intrusive and extrusive igneous rocks ranging in composition from granite to tonalite. Our new geochronologic and isotopic data show that the emplacement history of the plutonic rocks of the Killingworth dome is more complicated than previously thought. Geochemical and isotopic data indicate that this suite of igneous rocks was formed from diverse sources in both the Ordovician and Carboniferous. Moreover, in contrast to the geological record of much of New England, evidence of regional Acadian (Devonian) metamorphic overprinting is lacking. Rather, there is compelling evidence that these rocks were strongly metamorphosed, locally partially melted, and assembled by ductile faulting in the Carboniferous. The details of these interpretations are presented below to establish a new tectonic affinity for the Killingworth dome rocks in this area located 


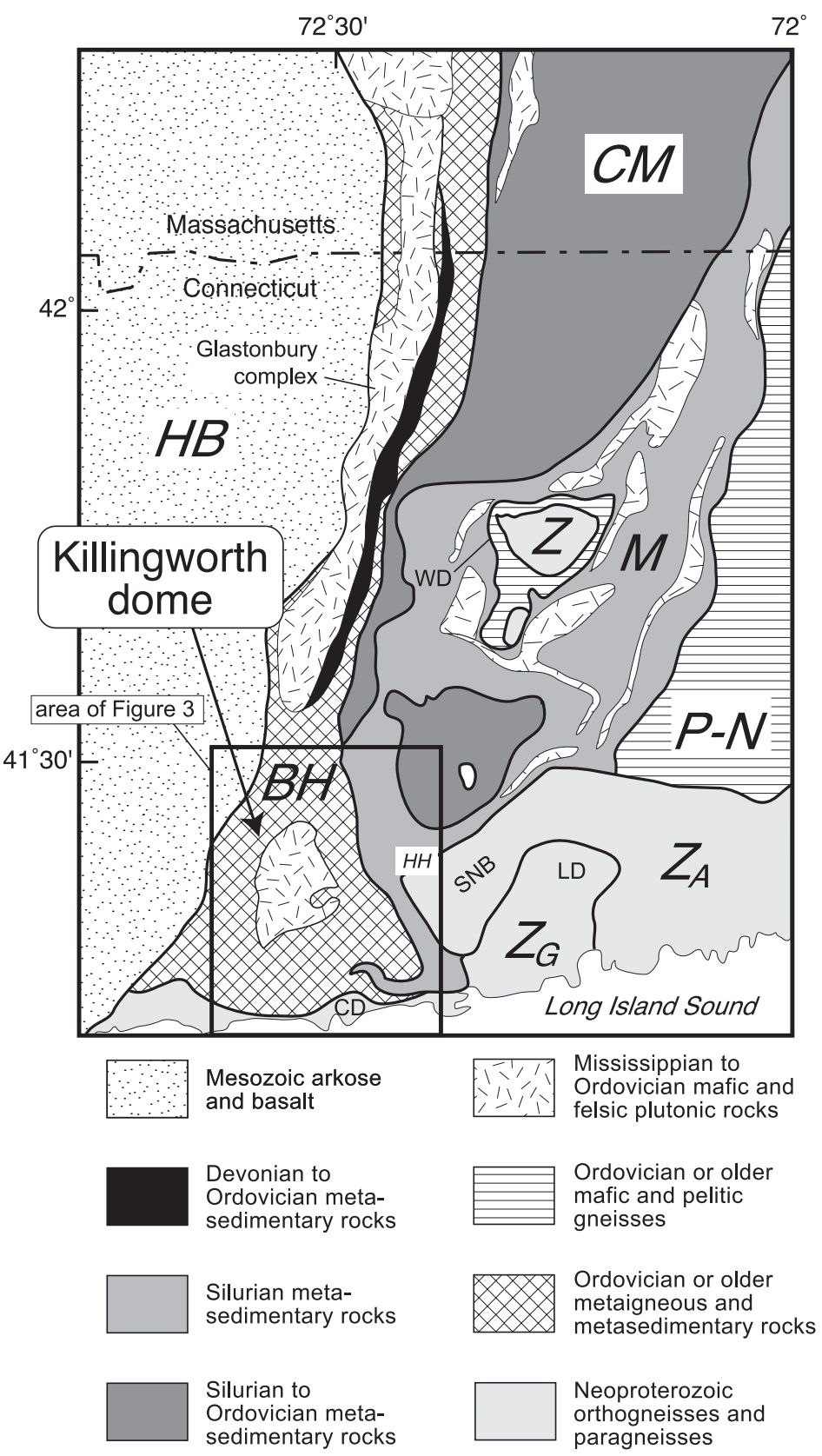

contact

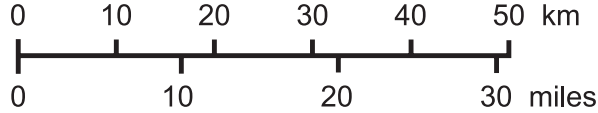

fault

Fig. 2. Generalized geologic map of southern New England (modified from Wintsch and others, 2003). Abbreviations: BH (Bronson Hill), CM (Central Maine), HB (Hartford basin), M (Merrimack), P-N (Putnam-Nashoba), $\mathrm{Z}$ (Neoproterozic rocks, subdivided into $\mathrm{Z}_{\mathrm{A}}$-Avalon, $\mathrm{Z}_{\mathrm{G}}$-Gander), $\mathrm{CD}$ (Clinton dome), LD (Lyme dome), SNB (Selden Neck block), WD (Willimantic dome), HH (Honey Hill fault). 
at the intersection of the Bronson Hill, Central Maine, Merrimack, Gander, and Avalon terranes (fig. 2).

\section{GEOLOGIC SETTING}

Orthogneisses within the Killingworth dome occur between metasedimentary rocks of the Central Maine and Merrimack terranes to the east, Neoproterozoic orthogneisses and paragneisses to the south, and Mesozoic arkoses of the Hartford basin to the west (fig. 2). The Killingworth dome traditionally has been considered to belong to the Bronson Hill Anticlinorium (Rodgers, 1985) or terrane (Wintsch and others, 2005). The orthogneisses consist primarily of plagioclase + quartz, with lesser amounts of biotite and amphibole. This limited range of modal compositions has made field and petrographic subdivision of the felsic rocks difficult (Mikami and Digman, 1957; Lundgren and Thurell, 1973). Various lithologies have been recognized, but boundaries were not identified in the field. Consequently, this lithologic assemblage has been collectively described as an undivided body of plagioclase gneiss in most previous geological investigations (for example, Percival, 1842; Rice and Gregory, 1906; Foye, 1949; Rodgers and others, 1959; Dixon and Lundgren, 1968). Distinctions between these lithologies were based on: (1) km-scale compositional zoning of plagioclase in the core region (Mikami and Digman, 1957), (2) degree of foliation development, and (3) modal content of biotite and amphibole in the Clinton quadrangle (Lundgren and Thurell, 1973). These relatively imprecise distinguishing characteristics led Rodgers (1985) to assign all varieties of these plagioclase gneisses to the Monson Gneiss. The outer margin of the Killingworth dome is occupied by metavolcanic and metasedimentary rocks of the Middletown and Collins Hill Formations.

Webster and Wintsch (1987) recognized that rocks of the Killingworth dome could be subdivided into distinct units on the basis of major- and trace-element compositions and map-scale distribution (fig. 3). These units were originally identified by reference to their geographic location around the dome (western, eastern southern, and central gneisses), but none were formally named. Our new results reinforce the interpretation that these bodies are petrologically distinct, thus justifying names for each unit. In contrast to previous studies, we regard these rocks as igneous lithodemic units rather than lithostratigraphic units. We follow the North American Stratigraphic Code (1983) in discriminating between groups and complexes, and formations and lithodemes. Use of new names supersedes Rodgers' (1985) assignment of these rocks to the Monson Gneiss because of unproven geologic continuity with Monson rocks at the type locality in Massachusetts. We follow the time scale of Gradstein and others (2004).

RESULTS

In this study, we supplement and expand on the work of Webster and Wintsch (1987). Our data confirm the designation of distinct orthogneiss bodies, and we establish ages and origins of these units. Thus, we have replaced the informal, geographically-based names used by Webster and Wintsch (1987) with the following new (informal) nomenclature: Higganum gneiss (formerly "western gneiss"), Pond Meadow gneiss (formerly "eastern gneiss"), Boulder Lake gneiss (formerly "southern gneiss;" originally called "Boulder Lake variety" of the Monson Gneiss for rocks in the adjacent Clinton 7.5-minute quadrangle by Lundgren and Thurrell, 1973), and Hidden Lake gneiss (formerly "central gneiss"). We retain the name "Turkey Hill belt of Monson Gneiss" (Lundgren, 1963) for a narrow belt of rocks on the east side of the Killingworth dome that Rodgers (1985) correlated with other rocks called Monson Gneiss in north-central Connecticut and Massachusetts (Tucker and Robinson, 1990). The formal name of Clinton Granite Gneiss (Lundgren, 1964) is retained for rocks 

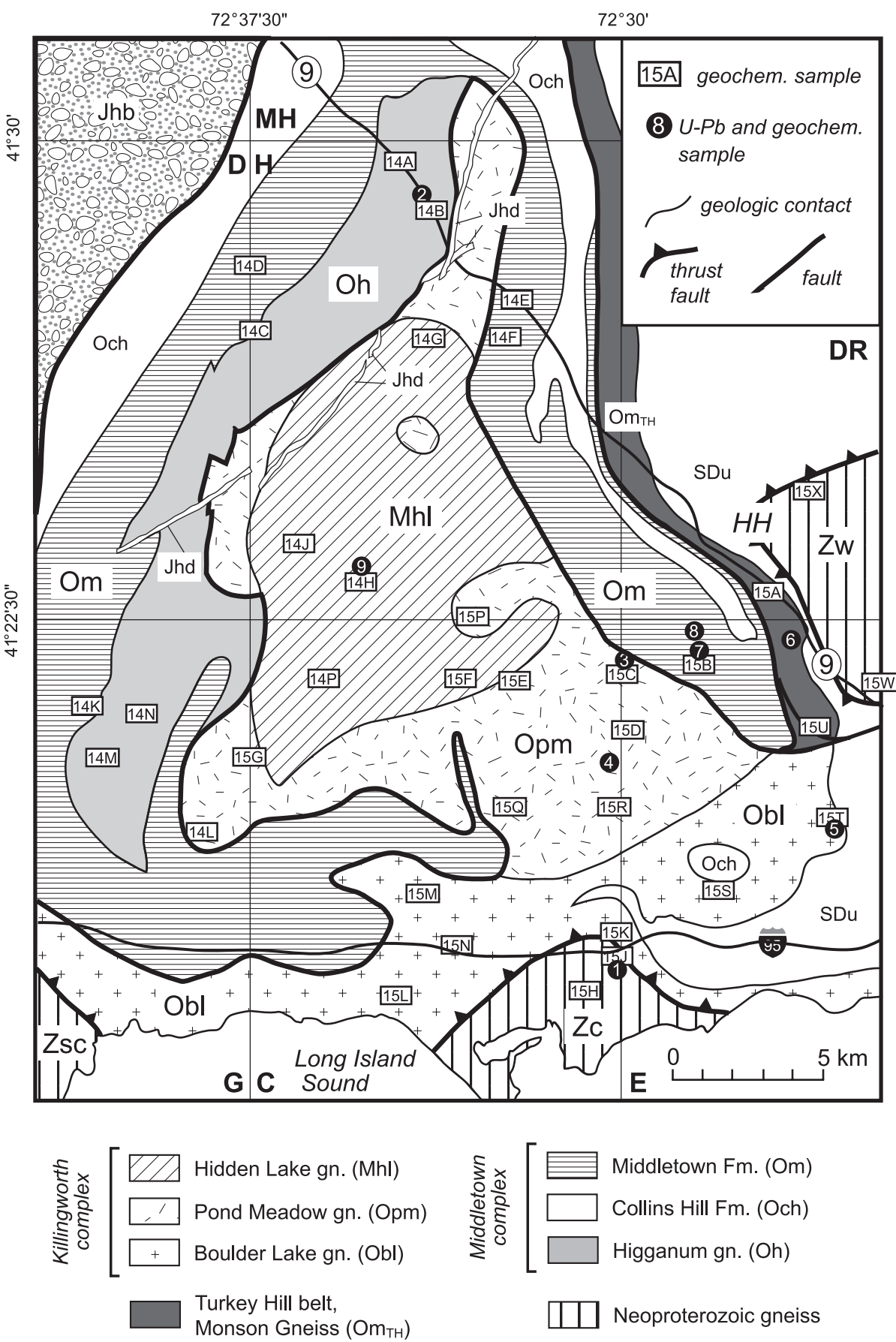

Fig. 3. Geologic map of the Killingworth dome, modified from Rodgers (1985). Lithologic subdivision of the Killingworth dome based on Webster and Wintsch (1987). Quadrangle abbreviations: C (Clinton), D (Durham), DR (Deep River), E (Essex), G (Guilford), H (Haddam), MH (Middle Haddam). Abbreviations: Jhb (Jurassic clastic sediments of the Hartford basin), Jhd (Jurassic Higganum dike), Och (Collins Hill), $\mathrm{Om}_{\mathrm{TH}}$ (Turkey Hill belt (Lundgren, 1963) of Monson Gneiss), SDu (Silurian and Devonian metaigneous and metasedimentary rocks, undifferentiated), Zc (Clinton Granite Gneiss), Zsc (Stony Creek Gneiss), Zw (Waterford Group), HH (Honey Hill fault). Fault contact surrounding Middletown-Higganum-Collins Hill rocks is an interpretation based on data in this paper (see Discussion section). 


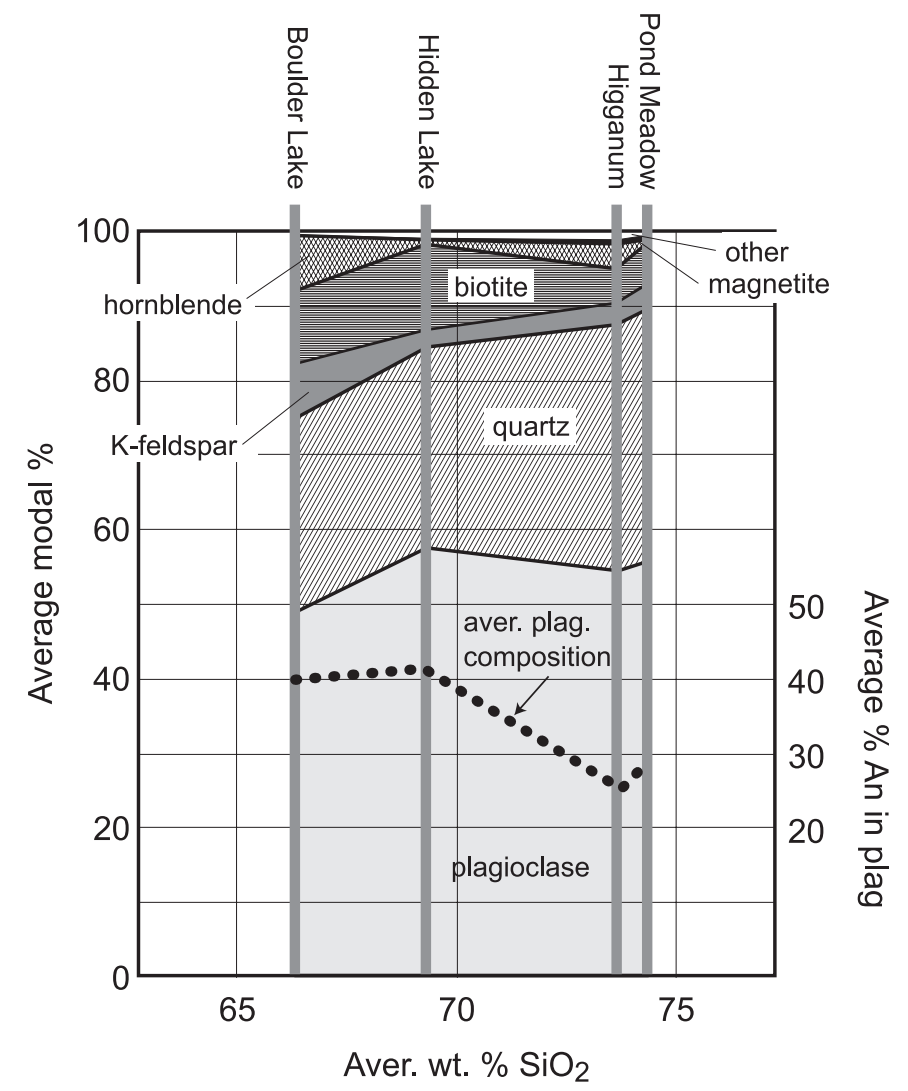

Fig. 4. Average modal compositions and average plagioclase composition (expressed as mol. \% An) of lithologies in the Killingworth dome.

that crop out in the Clinton dome, south of the Killingworth dome along the Connecticut coast. The formal name Middletown Formation (Lundgren, 1963) is retained for anthophyllite-bearing quartz-plagioclase gneiss and interbedded amphibolite that occur on the outer margins of the Killingworth dome (fig. 3; Rodgers, 1985). On the basis of field occurrence, plus new geochemistry and isotopic data, we now group lithologic units that occur within the Killingworth dome into two informallynamed complexes: (1) Killingworth complex (includes Boulder Lake, Pond Meadow, and Hidden Lake gneisses), and (2) Middletown complex (includes Middletown and Collins Hill Formations, and Higganum gneiss). The criteria for these groupings are discussed below.

All orthogneisses contain 50 to 60 modal percent plagioclase, 25 to 30 percent quartz, variable amounts of minor biotite, hornblende, K-feldspar, and magnetite, and trace garnet (fig. 4). For example, the hornblende/biotite ratios of the Boulder Lake and Higganum gneisses are higher than in the Hidden Lake and Pond Meadow gneisses. The minor minerals are typical, but not always diagnostic, of individual lithologic map units. In the western part of the study area, most primary mineralogical and textural features have been overprinted by moderate- to high-grade metamorphism and deformation; in the eastern part, overprinting also includes Late Paleozoic anatexis. Thus, the overall compositional similarity of most gneissic units and the pervasive regional gneissosity make it difficult to distinguish the orthogneisses in the 
field. Nevertheless, our study indicates that whole-rock compositions and zircon age data largely survived high-grade metamorphism. As a result, we employ these characteristics in subdividing the lithologies and interpreting the geologic evolution of their protoliths.

\section{Geochemistry}

A total of 35 new samples from five units within the Killingworth dome (Killingworth and Middletown complexes) were collected for geochemical analysis (fig. 3, table 1). Analytical procedures for determination of concentrations of major elements and selected trace elements are described in the Appendix. This new data set supports the findings of Webster and Wintsch (1987) and offers additional perspectives because it includes analyses of trace elements not reported in the previous study. The data reported here are considered separately from the results in Webster and Wintsch (1987) because the data sets were collected by different analytical methods using different standards.

Orthogneisses of the Killingworth dome vary considerably in major-element composition, ranging from about 64 to 77 weight percent $\mathrm{SiO}_{2}$ (table 1, figs. 5 and 6 ). Lithologic nomenclature for both the orthogneisses and metavolcanic rocks of the Middletown Formation is determined using standard procedures (figs. 5A and 5B, respectively). These diagrams involve use of alkali element concentrations that may have been susceptible to remobilization during metamorphism and/or anatexis. Nevertheless, we suggest that the clustering of data characterizing individual units indicates that such metasomatic effects are limited. Normative compositions indicate that the igneous protoliths of these rocks largely varied from tonalite to trondhjemite (fig. 5A). Felsic rocks of the Middletown Formation differ from the Killingworth orthogneisses in displaying exclusively trondhjemitic compositions. The Middletown Formation also is distinctive in that it contains a bimodal lithologic association including rocks of both rhyolitic and andesitic affinity (fig. 5B), reflecting bimodality in the original magmatic compositions. The three mafic samples are widely distributed structurally and geographically around the complex, suggesting that rocks of this composition constitute an important component of the Middletown volcanic stratigraphy. As noted by Webster and Wintsch (1987), geochemical trends exhibited by most of the orthogneisses likely reflect the effects of primary magmatic processes. However, all rocks have experienced high-grade metamorphic conditions, and the southern half of the Killingworth complex is pervasively migmatitic. In some rocks, the high metamorphic grade is shown by patchy zones of tonalite with a subhedral granular (magmatic) texture interrupting an older wispy gneissic fabric (Wintsch and others, 2005). In other rocks, younger migmatitic textures are associated with an increase in modal K-feldspar. Migmatization is typical of all rocks of the southern part of the Killingworth dome. Although care was taken in collecting samples to avoid the effects of local migmatization, geochemical evidence of this anatexis is apparent from the scattered compositional data obtained from a small number of samples. This is illustrated by the relatively high normative orthoclase (Or) content of two samples (fig. $5 \mathrm{~A}$ ), decoupling of $\mathrm{Na}_{2} \mathrm{O}$ and $\mathrm{K}_{2} \mathrm{O}$ (table 1), and considerable variation in $\mathrm{TiO}_{2}$ (fig. $6 \mathrm{~A}$ ) in the Hidden Lake gneiss at the high end of its silica range. Similar effects are exhibited by alkalies in some samples from the Higganum and Boulder Lake units. Such local variation notwithstanding, the preponderance of data from these samples defines coherent clusters and trends (fig. 6), supporting the compositionally-based distinction of lithologic units proposed by Webster and Wintsch (1987).

In spite of local variation in alkali contents that results in anomalous data on variation plots, the majority of geochemical data indicate that differences in aluminosity [expressed as aluminum saturation index $=$ molar $\left(\mathrm{Al}_{2} \mathrm{O}_{3} /\left(\mathrm{CaO}+\mathrm{Na}_{2} \mathrm{O}+\mathrm{K}_{2} \mathrm{O}\right)\right.$ (fig. 6D)] between the dominantly metaluminous Boulder Lake gneiss and other 
TABLE 1

Geochemical analyses of samples from the Killingworth and Middletown complexes

\begin{tabular}{|c|c|c|c|c|c|c|c|c|c|}
\hline Field No. & $14 \mathrm{G}$ & $14 \mathrm{H}$ & $14 \mathrm{~J}$ & $14 \mathrm{P}$ & $15 \mathrm{~F}$ & 1BW8.11.01 & $14 \mathrm{~L}$ & $15 \mathrm{C}$ & $15 \mathrm{D}$ \\
\hline & Hidden & Hidden & Hidden & Hidden & Hidden & Hidden & Pond & Pond & Pond \\
\hline Unit & Lake & Lake & Lake & Lake & Lake & Lake & Meadow & Meadow & Meadow \\
\hline$\overline{\mathrm{SiO}_{2}}$ & 68.0 & 66.8 & 69.2 & 66.2 & 70.1 & 70.6 & 75.1 & 72.4 & 72.5 \\
\hline $\mathrm{Al}_{2} \mathrm{O}_{3}$ & 17.5 & 16.6 & 15.4 & 16.4 & 14.8 & 13.8 & 12.7 & 14.1 & 14.3 \\
\hline $\mathrm{Fe}_{2} \mathrm{O}_{3} *$ & 2.32 & 3.65 & 3.34 & 3.90 & 3.16 & 2.88 & 2.98 & 3.33 & 3.45 \\
\hline $\mathrm{MgO}$ & 0.72 & 1.39 & 1.17 & 1.52 & 1.09 & 0.69 & 0.73 & 0.70 & 0.60 \\
\hline $\mathrm{CaO}$ & 4.12 & 4.75 & 4.12 & 5.20 & 3.10 & 1.73 & 2.28 & 3.44 & 3.47 \\
\hline $\mathrm{Na}_{2} \mathrm{O}$ & 4.26 & 3.39 & 3.29 & 3.07 & 3.09 & 2.17 & 3.46 & 3.16 & 3.85 \\
\hline $\mathrm{K}_{2} \mathrm{O}$ & 1.59 & 1.53 & 1.54 & 1.50 & 3.02 & 5.69 & 1.21 & 0.96 & 0.90 \\
\hline $\mathrm{TiO}_{2}$ & 0.21 & 0.38 & 0.29 & 0.40 & 0.34 & 0.51 & 0.23 & 0.17 & 0.19 \\
\hline $\mathrm{P}_{2} \mathrm{O}_{5}$ & 0.08 & 0.21 & 0.12 & 0.18 & 0.16 & 0.17 & 0.08 & 0.09 & 0.09 \\
\hline $\mathrm{MnO}$ & 0.04 & 0.05 & 0.05 & 0.05 & 0.06 & 0.03 & 0.08 & 0.08 & 0.06 \\
\hline LOI & 0.59 & 0.51 & 0.46 & 0.64 & 0.41 & 0.49 & 0.69 & 0.76 & 0.37 \\
\hline Total & 99.43 & 99.26 & 98.98 & 99.06 & 99.33 & 98.76 & 99.54 & 99.19 & 99.78 \\
\hline $\mathrm{Rb}$ & 61 & 51 & 39 & 49 & 89 & 132 & 78 & 50 & 40 \\
\hline $\mathrm{Ba}$ & 988 & 1098 & 1662 & 916 & 1589 & 4073 & 385 & 201 & 188 \\
\hline $\mathrm{Sr}$ & 573 & 655 & 536 & 555 & 433 & 375 & 83 & 96 & 120 \\
\hline$T h \dagger$ & 3.12 & 2.91 & 5.13 & 4.49 & 15.40 & 61.90 & 4.97 & 3.57 & 3.85 \\
\hline$U$ & 1.21 & 0.73 & 1.35 & 0.68 & 1.52 & 1.76 & 2.26 & 1.29 & 0.61 \\
\hline $\mathrm{Zr}$ & 86 & 62 & 61 & 71 & 106 & 342 & 73 & 58 & 73 \\
\hline$H f$ & 2.13 & 2.56 & 2.11 & 2.80 & 5.11 & 8.36 & 3.26 & 2.26 & 2.76 \\
\hline $\mathrm{Nb}$ & 13 & 4 & 2 & 2 & 7 & 1 & 1 & 2 & 2 \\
\hline $\mathrm{Ta}$ & 1.56 & 0.48 & 0.30 & 0.14 & 0.70 & 0.11 & 0.24 & 0.24 & 0.45 \\
\hline$N i$ & 1 & 7 & 9 & 9 & 4 & 4 & 7 & 6 & 6 \\
\hline$Z n$ & 34 & 50 & 38 & 59 & 51 & 46 & 48 & 45 & 42 \\
\hline $\mathrm{Cr}$ & 7 & 7 & 9 & 10 & 12 & 8 & 5 & 4 & 7 \\
\hline$S c$ & 3.62 & 3.79 & 6.44 & 8.15 & 5.86 & 3.18 & 11.40 & 11.50 & 6.52 \\
\hline La & 12.20 & 14.40 & 18.20 & 19.30 & 49.50 & 103.00 & 17.50 & 14.20 & 13.10 \\
\hline $\mathrm{Ce}$ & 18.00 & 24.40 & 30.20 & 32.00 & 90.20 & 181.00 & 32.50 & 26.80 & 25.00 \\
\hline$N d$ & 6.92 & 7.94 & 10.30 & 10.50 & 31.00 & 52.70 & 15.00 & 12.70 & 11.30 \\
\hline$S m$ & 0.98 & 1.22 & 1.68 & 1.65 & 4.09 & 6.63 & 3.71 & 2.63 & 2.19 \\
\hline$E u$ & 0.42 & 0.42 & 0.49 & 0.50 & 0.89 & 1.16 & 0.57 & 0.54 & 0.56 \\
\hline$G d$ & 1.03 & 0.93 & 1.43 & 1.57 & 3.13 & 3.80 & 3.84 & 2.57 & 2.02 \\
\hline$T b$ & 0.14 & 0.12 & 0.18 & 0.17 & 0.36 & 0.30 & 0.61 & 0.38 & 0.23 \\
\hline Ho & 0.18 & 0.12 & 0.24 & 0.20 & 0.40 & 0.28 & 0.82 & 0.69 & 0.25 \\
\hline Tm & 0.06 & 0.05 & 0.09 & 0.06 & 0.15 & 0.06 & 0.45 & 0.37 & 0.07 \\
\hline$Y b$ & 0.38 & 0.26 & 0.52 & 0.37 & 0.90 & 0.36 & 2.96 & 2.46 & 0.48 \\
\hline$L u$ & 0.06 & 0.04 & 0.08 & 0.05 & 0.13 & 0.06 & 0.45 & 0.38 & 0.08 \\
\hline $\mathrm{Y}$ & 5 & 4 & 5 & 6 & 11 & 10 & 20 & 16 & 4 \\
\hline
\end{tabular}

peraluminous units is not a manifestation of local migmatization. Instead, these differences likely are a reflection of igneous processes, including both source-related characteristics and possible differentiation. The metaluminous Boulder Lake rocks (fig. 6D), characterized by relatively low silica contents and high concentrations of compatible major elements (figs. 6A-C, F), are the least compositionally evolved of the intermediate to felsic gneisses. In contrast, the Pond Meadow and Higganum gneisses display the most evolved compositions, with $\mathrm{SiO}_{2}$ contents in excess of 70 weight percent. The Hidden Lake gneiss, intermediate in $\mathrm{SiO}_{2}$ content between the Boulder Lake and Pond Meadow gneisses, plots apart from the trend defined by the other units in $\mathrm{FeOt}$ (total iron expressed as $\mathrm{FeO}$ ) (fig. 6E) and the feldspar-compatible trace 
TABLE 1

(continued)

\begin{tabular}{|c|c|c|c|c|c|c|c|c|c|}
\hline Field No & $15 \mathrm{E}$ & $15 \mathrm{P}$ & $15 \mathrm{R}$ & 3BS8.11.01 & $15 \mathrm{G}$ & $15 Q$ & $15 \mathrm{~K}$ & $15 \mathrm{~L}$ & $15 \mathrm{M}$ \\
\hline & Pond & Pond & Pond & Pond & Pond & Pond & Boulder & \multicolumn{2}{|c|}{ Boulder Boulder } \\
\hline Unit & Meadow & Meadow & Meadow & Meadow & Meadow & Meadow & Lake & Lake & Lake \\
\hline$\overline{\mathrm{SiO}_{2}}$ & 71.9 & 77.0 & 73.2 & 71.1 & 76.4 & 70.4 & 74.3 & 63.8 & 66.6 \\
\hline $\mathrm{Al}_{2} \mathrm{O}_{3}$ & 13.9 & 12.0 & 14.2 & 14.9 & 12.2 & 14.8 & 13.0 & 15.3 & 15.1 \\
\hline $\mathrm{Fe}_{2} \mathrm{O}_{3}$ * & 3.66 & 2.19 & 2.63 & 3.40 & 2.76 & 4.36 & 2.17 & 6.65 & 5.73 \\
\hline $\mathrm{MgO}$ & 1.17 & 0.51 & 0.71 & 0.81 & 0.41 & 0.87 & 0.56 & 2.37 & 1.95 \\
\hline $\mathrm{CaO}$ & 3.70 & 1.69 & 2.90 & 3.55 & 1.66 & 3.83 & 1.72 & 6.15 & 4.67 \\
\hline $\mathrm{Na}_{2} \mathrm{O}$ & 3.28 & 3.67 & 3.82 & 3.92 & 3.74 & 3.45 & 3.05 & 2.60 & 2.73 \\
\hline $\mathrm{K}_{2} \mathrm{O}$ & 1.20 & 1.67 & 1.27 & 1.08 & 1.17 & 1.14 & 3.56 & 1.55 & 1.68 \\
\hline $\mathrm{TiO}_{2}$ & 0.28 & 0.12 & 0.21 & 0.22 & 0.16 & 0.25 & 0.20 & 0.48 & 0.42 \\
\hline $\mathrm{P}_{2} \mathrm{O}_{5}$ & 0.10 & 0.07 & 0.09 & 0.09 & 0.07 & 0.11 & 0.16 & 0.11 & 0.10 \\
\hline $\mathrm{MnO}$ & 0.08 & 0.03 & 0.04 & 0.06 & 0.09 & 0.11 & 0.04 & 0.12 & 0.10 \\
\hline LOI & 0.41 & 0.47 & 0.54 & 0.44 & 0.56 & 0.45 & 0.32 & 0.34 & 0.30 \\
\hline Total & 99.68 & 99.42 & 99.61 & 99.57 & 99.22 & 99.77 & 99.08 & 99.47 & 99.38 \\
\hline $\mathrm{Rb}$ & 58 & 52 & 56 & 44 & 41 & 55 & 106 & 63 & 70 \\
\hline $\mathrm{Ba}$ & 173 & 175 & 242 & 221 & 254 & 228 & 1105 & 284 & 373 \\
\hline $\mathrm{Sr}$ & 150 & 83 & 131 & 123 & 85 & 135 & 160 & 187 & 191 \\
\hline$T h \dagger$ & 7.52 & 5.75 & 4.47 & 3.61 & 6.20 & 5.84 & 34.50 & 8.97 & 7.60 \\
\hline$U$ & 1.26 & 2.10 & 0.88 & 2.70 & 1.37 & 1.40 & 1.78 & 1.17 & 2.45 \\
\hline $\mathrm{Zr}$ & 58 & 107 & 62 & 54 & 75 & 62 & 130 & 108 & 94 \\
\hline$H f$ & 2.73 & 4.83 & 2.49 & 2.23 & 3.02 & 1.90 & 4.32 & 3.05 & 3.37 \\
\hline $\mathrm{Nb}$ & 3 & 3 & 7 & 3 & 13 & 2 & 10 & 4 & 5 \\
\hline$T a$ & 0.50 & 0.14 & 0.49 & 0.47 & 0.80 & 0.58 & 0.28 & 0.39 & 1.28 \\
\hline$N i$ & 9 & 3 & 5 & 5 & 8 & 4 & 5 & 10 & 4 \\
\hline$Z n$ & 47 & 39 & 31 & 53 & 38 & 44 & 23 & 57 & 45 \\
\hline $\mathrm{Cr}$ & 18 & 6 & 7 & 15 & 7 & 8 & 9 & 15 & 10 \\
\hline$S c$ & 10.40 & 8.47 & 6.26 & 7.99 & 11.40 & 14.60 & 4.53 & 22.80 & 21.80 \\
\hline La & 16.00 & 19.10 & 9.55 & 11.20 & 17.80 & 16.30 & 48.50 & 23.00 & 17.90 \\
\hline $\mathrm{Ce}$ & 31.90 & 40.70 & 22.80 & 22.50 & 37.90 & 36.90 & 87.50 & 45.60 & 43.20 \\
\hline$N d$ & 15.20 & 20.60 & 9.51 & 10.10 & 19.10 & 15.30 & 32.70 & 19.30 & 15.20 \\
\hline Sm & 3.30 & 4.82 & 2.33 & 2.11 & 4.28 & 3.34 & 6.19 & 3.87 & 3.58 \\
\hline$E u$ & 0.61 & 0.69 & 0.57 & 0.57 & 0.68 & 0.67 & 0.98 & 0.78 & 0.74 \\
\hline$G d$ & 3.07 & 6.41 & 2.51 & 1.94 & 4.30 & 3.14 & 5.10 & 3.55 & 3.35 \\
\hline$T b$ & 0.51 & 1.11 & 0.37 & 0.23 & 0.66 & 0.45 & 0.57 & 0.51 & 0.56 \\
\hline Ho & 0.70 & 2.27 & 0.44 & 0.27 & 0.77 & 0.82 & 0.51 & 0.70 & 0.83 \\
\hline $\mathrm{Tm}$ & 0.29 & 1.18 & 0.14 & 0.09 & 0.24 & 0.46 & 0.20 & 0.35 & 0.43 \\
\hline$Y b$ & 1.75 & 7.84 & 0.82 & 0.56 & 1.44 & 3.13 & 1.13 & 2.21 & 2.87 \\
\hline Lu & 0.27 & 1.20 & 0.13 & 0.08 & 0.20 & 0.49 & 0.17 & 0.33 & 0.43 \\
\hline$\underline{Y}$ & 15 & 49 & 8 & 6 & 18 & 20 & 15 & 19 & 23 \\
\hline
\end{tabular}

elements $\mathrm{Sr}$ and $\mathrm{Ba}$ (figs. $6 \mathrm{G}$ and $6 \mathrm{H}$, respectively), and thus is unlikely to share a common petrologic lineage. In contrast, the Higganum gneiss and felsic Middletown Formation exhibit similarities in trace-element concentrations that suggest a petrologic relationship between these units. Systematic decrease in $\mathrm{CaO}$ and $\mathrm{Sr}$ with increasing silica content for all Ordovician units (figs. 6B and 6G) points toward a petrologic origin in which differentiation of plagioclase feldspar was important.

\section{Geochronology}

With the lithologic differences found by Webster and Wintsch (1987) confirmed here, we determined the age of each unit of the Killingworth dome. In addition, we 
TABLE 1

(continued)

\begin{tabular}{|c|c|c|c|c|c|c|c|c|c|}
\hline Field No. & $15 \mathrm{~N}$ & $15 \mathrm{~S}$ & $15 \mathrm{~T}$ & 4BS8.11.01 & $14 \mathrm{~A}$ & 14B & $14 \mathrm{M}$ & $14 \mathrm{~N}$ & HA-1-02 \\
\hline Unit & $\begin{array}{c}\text { Boulder } \\
\text { Lake }\end{array}$ & $\begin{array}{c}\text { Boulder } \\
\text { Lake }\end{array}$ & $\begin{array}{c}\text { Boulder } \\
\text { Lake }\end{array}$ & $\begin{array}{l}\text { Boulder } \\
\text { Lake }\end{array}$ & Higganum & Higganum & Higganum & Higganum & Higganum \\
\hline$\overline{\mathrm{SiO}_{2}}$ & 66.0 & 67.4 & 64.3 & 67.6 & 71.5 & 75.6 & 72.2 & 72.3 & 71.7 \\
\hline $\mathrm{Al}_{2} \mathrm{O}_{3}$ & 14.9 & 14.6 & 15.5 & 15.0 & 13.4 & 12.1 & 13.6 & 13.3 & 13.4 \\
\hline $\mathrm{Fe}_{2} \mathrm{O}_{3} *$ & 5.77 & 5.77 & 6.10 & 5.22 & 5.34 & 3.86 & 4.46 & 4.21 & 4.86 \\
\hline $\mathrm{MgO}$ & 1.91 & 1.14 & 2.18 & 1.64 & 1.06 & 0.87 & 1.23 & 1.41 & 1.06 \\
\hline $\mathrm{CaO}$ & 4.73 & 6.17 & 5.48 & 4.35 & 4.23 & 1.76 & 2.85 & 1.75 & 3.81 \\
\hline $\mathrm{Na}_{2} \mathrm{O}$ & 2.85 & 2.90 & 3.09 & 3.05 & 3.61 & 4.37 & 4.57 & 4.39 & 3.50 \\
\hline $\mathrm{K}_{2} \mathrm{O}$ & 2.32 & 0.49 & 1.50 & 1.78 & 0.49 & 0.55 & 0.17 & 1.52 & 0.82 \\
\hline $\mathrm{TiO}_{2}$ & 0.41 & 0.42 & 0.44 & 0.42 & 0.37 & 0.17 & 0.40 & 0.28 & 0.28 \\
\hline $\mathrm{P}_{2} \mathrm{O}_{5}$ & 0.11 & 0.15 & 0.15 & 0.11 & 0.10 & 0.07 & 0.12 & 0.09 & 0.10 \\
\hline $\mathrm{MnO}$ & 0.10 & 0.15 & 0.13 & 0.09 & 0.11 & 0.08 & 0.09 & 0.09 & 0.10 \\
\hline LOI & 0.49 & 0.34 & 0.28 & 0.16 & $<0.01$ & $<0.01$ & 0.06 & 0.50 & 0.25 \\
\hline Total & 99.59 & 99.53 & 99.15 & 99.42 & 100.21 & 99.43 & 99.75 & 99.84 & 99.88 \\
\hline $\mathrm{Rb}$ & 82 & 4 & 74 & 87 & 10 & 10 & 2 & 113 & 21 \\
\hline $\mathrm{Ba}$ & 537 & 129 & 325 & 348 & 90 & 67 & 81 & 164 & 113 \\
\hline $\mathrm{Sr}$ & 188 & 273 & 199 & 185 & 89 & 99 & 165 & 100 & 89 \\
\hline$T h \dagger$ & 8.27 & 2.53 & 12.20 & 9.48 & 1.03 & 0.88 & 3.66 & 0.39 & 1.50 \\
\hline$U$ & 2.62 & 1.15 & 1.98 & 0.86 & 0.81 & 0.86 & 1.65 & 6.77 & 0.85 \\
\hline $\mathrm{Zr}$ & 85 & 58 & 87 & 95 & 93 & 98 & 82 & 74 & 51 \\
\hline$H f$ & 3.09 & 1.90 & 2.67 & 3.52 & 3.44 & 3.27 & 2.52 & 2.82 & 2.38 \\
\hline $\mathrm{Nb}$ & 2 & 2 & 4 & 8 & 3 & 0 & 2 & 7 & 0 \\
\hline$T a$ & 0.42 & 0.17 & 1.03 & 0.70 & 0.20 & 0.17 & 0.21 & 0.76 & 0.25 \\
\hline$N i$ & 9 & 6 & 0 & 6 & 5 & 2 & 3 & 4 & 4 \\
\hline$Z n$ & 36 & 124 & 41 & 41 & 67 & 35 & 30 & 40 & 56 \\
\hline $\mathrm{Cr}$ & 10 & 4 & 7 & 18 & 6 & 16 & 4 & 4 & 15 \\
\hline$S c$ & 19.60 & 24.70 & 22.50 & 18.20 & 35.70 & 8.68 & 16.50 & 22.60 & 17.00 \\
\hline La & 20.80 & 6.50 & 30.20 & 26.40 & 3.91 & 3.05 & 12.50 & 2.17 & 4.58 \\
\hline $\mathrm{Ce}$ & 38.80 & 22.30 & 56.00 & 50.20 & 9.35 & 6.58 & 27.80 & 4.18 & 10.70 \\
\hline$N d$ & 16.90 & 11.80 & 23.40 & 22.80 & 6.74 & 5.15 & 13.60 & 3.00 & 6.91 \\
\hline$S m$ & 3.79 & 3.95 & 4.76 & 4.64 & 2.86 & 1.56 & 3.81 & 0.99 & 2.46 \\
\hline$E u$ & 0.78 & 1.04 & 0.93 & 0.83 & 0.67 & 0.65 & 0.81 & 0.36 & 0.55 \\
\hline$G d$ & 3.54 & 5.10 & 4.40 & 4.08 & 3.99 & 2.02 & 4.18 & 1.11 & 3.19 \\
\hline$T b$ & 0.46 & 0.83 & 0.63 & 0.53 & 0.75 & 0.39 & 0.72 & 0.22 & 0.61 \\
\hline Ho & 0.75 & 1.28 & 0.88 & 0.70 & 1.27 & 0.72 & 1.14 & 0.34 & 1.10 \\
\hline $\mathrm{Tm}$ & 0.41 & 0.68 & 0.39 & 0.28 & 0.60 & 0.40 & 0.51 & 0.16 & 0.58 \\
\hline$Y b$ & 2.57 & 4.53 & 2.40 & 1.57 & 3.90 & 2.69 & 3.46 & 1.01 & 3.66 \\
\hline$L u$ & 0.39 & 0.67 & 0.36 & 0.22 & 0.61 & 0.45 & 0.54 & 0.14 & 0.58 \\
\hline Y & 19 & 25 & 18 & 18 & 28 & 16 & 27 & 7 & 25 \\
\hline
\end{tabular}

dated granitic gneiss from the Clinton dome (fig. 3). The geochronology results are described below in chronological order, from oldest to youngest. Isotopic data for zircon are shown on Tera-Wasserburg concordia plots; ages are calculated by determining the weighted average of selected ${ }^{206} \mathrm{~Pb} /{ }^{238} \mathrm{U}$ ages. Isotopic data (uncorrected for common $\mathrm{Pb}$ ) from titanite are shown on a Tera-Wasserburg concordia plot and are regressed to calculate a lower intercept age. Geochronologic techniques, including a discussion of the age of our titanite standard (determined by thermal ionization mass spectrometry), are described in the Appendix.

Clinton Granite Gneiss.-The Clinton Granite Gneiss of Lundgren (1964) and Lundgren and Thurell (1973) occurs structurally below the Killingworth dome in the 
TABLE 1

(continued)

\begin{tabular}{|c|c|c|c|c|c|c|c|c|}
\hline Field No. & 14D & $14 \mathrm{E}$ & $14 \mathrm{~F}$ & $14 \mathrm{~K}$ & $15 \mathrm{~B}$ & $14 \mathrm{C}$ & 2BS8.11.01 & 16BS11.11.02 \\
\hline Unit & $\begin{array}{l}\text { Middle- } \\
\text { town }\end{array}$ & $\begin{array}{l}\text { Middle- } \\
\text { town }\end{array}$ & $\begin{array}{l}\text { Middle- } \\
\text { town }\end{array}$ & $\begin{array}{l}\text { Middle- } \\
\text { town }\end{array}$ & $\begin{array}{l}\text { Middle- } \\
\text { town }\end{array}$ & $\begin{array}{l}\text { Middle- } \\
\text { town }\end{array}$ & $\begin{array}{l}\text { Middle- } \\
\text { town }\end{array}$ & $\begin{array}{l}\text { Middle- } \\
\text { town }\end{array}$ \\
\hline$\overline{\mathrm{SiO}_{2}}$ & 56.8 & 73.3 & 55.4 & 54.8 & 73.7 & 76.2 & 74.3 & 72.5 \\
\hline $\mathrm{Al}_{2} \mathrm{O}_{3}$ & 14.9 & 12.8 & 15.6 & 15.2 & 12.2 & 12.5 & 12.2 & 13.1 \\
\hline $\mathrm{Fe}_{2} \mathrm{O}_{3}$ * & 12.3 & 3.73 & 8.40 & 12.6 & 4.40 & 3.48 & 4.47 & 2.55 \\
\hline $\mathrm{MgO}$ & 5.38 & 2.17 & 6.62 & 4.13 & 1.79 & 0.48 & 1.24 & 1.48 \\
\hline $\mathrm{CaO}$ & 3.02 & 2.23 & 6.65 & 6.71 & 1.96 & 1.41 & 1.60 & 3.24 \\
\hline $\mathrm{Na}_{2} \mathrm{O}$ & 5.64 & 4.28 & 5.54 & 3.98 & 4.62 & 4.68 & 4.63 & 5.24 \\
\hline $\mathrm{K}_{2} \mathrm{O}$ & 0.15 & 0.17 & 0.13 & 0.41 & 0.16 & 0.53 & 0.35 & 0.16 \\
\hline $\mathrm{TiO}_{2}$ & 0.80 & 0.24 & 0.51 & 0.91 & 0.38 & 0.19 & 0.37 & 0.51 \\
\hline $\mathrm{P}_{2} \mathrm{O}_{5}$ & 0.22 & 0.10 & 0.12 & 0.10 & 0.12 & 0.08 & 0.10 & 0.17 \\
\hline $\mathrm{MnO}$ & 0.27 & 0.05 & 0.16 & 0.18 & 0.06 & 0.12 & 0.05 & 0.06 \\
\hline LOI & 0.12 & 0.42 & 0.55 & 0.12 & 0.09 & 0.22 & 0.08 & 0.14 \\
\hline Total & 99.60 & 99.49 & 99.68 & 99.14 & 99.48 & 99.89 & 99.39 & 99.15 \\
\hline $\mathrm{Rb}$ & 8 & 9 & 4 & 11 & 5 & 9 & 8 & 2 \\
\hline $\mathrm{Ba}$ & 50 & 36 & 58 & 22 & 51 & 79 & 88 & 58 \\
\hline $\mathrm{Sr}$ & 61 & 119 & 200 & 119 & 111 & 85 & 132 & 141 \\
\hline$T h \dagger$ & 0.50 & 0.35 & 0.44 & 1.00 & 4.79 & 1.08 & 4.48 & 4.27 \\
\hline$U$ & 0.23 & 0.38 & 0.13 & 0.43 & 1.58 & 1.01 & 1.87 & 1.33 \\
\hline $\mathrm{Zr}$ & 27 & 28 & 30 & 40 & 92 & 53 & 79 & 110 \\
\hline$H f$ & 1.00 & 0.94 & 0.94 & 1.26 & 3.31 & 2.37 & 2.81 & 3.38 \\
\hline $\mathrm{Nb}$ & 1 & 0 & 0 & 0 & 2 & 1 & 2 & 3 \\
\hline$T a$ & 0.11 & 0.11 & 0.06 & 0.13 & 0.19 & 0.24 & 0.20 & 0.23 \\
\hline$N i$ & 18 & 3 & 25 & 26 & 3 & 0 & 3 & 2 \\
\hline$Z n$ & 124 & 29 & 93 & 117 & 30 & 54 & 37 & 32 \\
\hline $\mathrm{Cr}$ & 14 & 7 & 123 & 14 & 6 & 5 & 12 & 12 \\
\hline$S c$ & 43.70 & 18.80 & 35.80 & 39.20 & 14.90 & 11.90 & 11.40 & 17.80 \\
\hline$L a$ & 2.26 & 1.97 & 2.88 & 3.75 & 15.70 & 4.01 & 14.00 & 13.70 \\
\hline $\mathrm{Ce}$ & 4.71 & 4.44 & 7.09 & 9.78 & 33.80 & 8.70 & 28.20 & 33.40 \\
\hline$N d$ & 4.17 & 2.64 & 4.40 & 6.07 & 18.00 & 5.29 & 15.80 & 18.80 \\
\hline $\mathrm{Sm}$ & 1.77 & 1.17 & 1.56 & 2.16 & 4.79 & 1.85 & 4.00 & 5.54 \\
\hline$E u$ & 0.70 & 0.46 & 0.60 & 0.64 & 0.92 & 0.57 & 0.85 & 1.35 \\
\hline$G d$ & 2.32 & 1.77 & 2.08 & 2.54 & 5.06 & 2.02 & 5.03 & 6.22 \\
\hline$T b$ & 0.44 & 0.33 & 0.34 & 0.51 & 0.89 & 0.44 & 0.77 & 1.06 \\
\hline Ho & 0.70 & 0.58 & 0.59 & 0.78 & 1.31 & 0.80 & 1.23 & 1.78 \\
\hline $\mathrm{Tm}$ & 0.34 & 0.33 & 0.32 & 0.39 & 0.67 & 0.37 & 0.62 & 0.82 \\
\hline$Y b$ & 2.12 & 2.08 & 1.93 & 2.47 & 4.53 & 2.45 & 4.24 & 5.29 \\
\hline Lu & 0.31 & 0.31 & 0.29 & 0.35 & 0.66 & 0.36 & 0.65 & 0.79 \\
\hline $\mathrm{Y}$ & 18 & 13 & 13 & 18 & 30 & 14 & 21 & 39 \\
\hline
\end{tabular}

Clinton dome along Long Island Sound (figs. 2 and 3). It is a tan- to cream-weathering granitic gneiss, with 0.5 to $1.0 \mathrm{~cm}$ equant grains of K-feldspar, quartz, and plagioclase, accompanied by minor biotite. A weak gneissosity is defined by local wispy biotite-rich folia present in most outcrops. The contact between the Clinton Granite Gneiss and the structurally higher Boulder Lake gneiss to the north is a ductile fault (fig. 3). Although both rocks are shown on the Bedrock Geologic Map of Connecticut (Rodgers, 1985) as Neoproterozoic, it has long been suspected that the fault is a terrane boundary along which intrusive Ordovician rocks of the Killingworth dome are 
74 J. N. Aleinikoff and others-Ages and origins of rocks of the Killingworth dome,

A

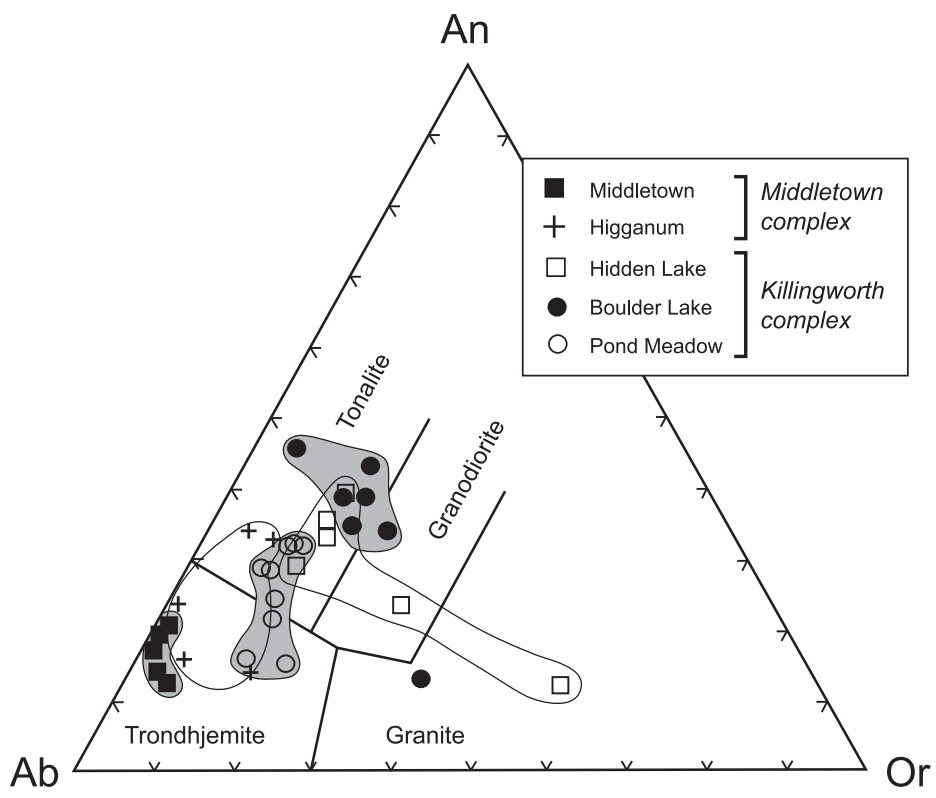

B

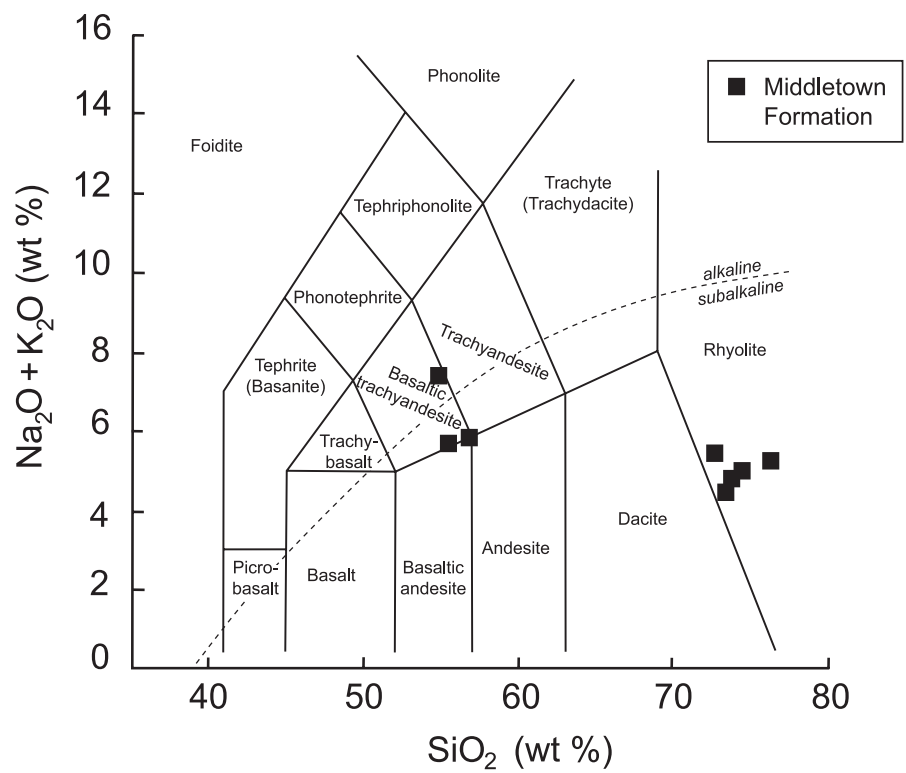

Fig. 5. Geochemical plots of whole-rock data from the Killingworth dome. (A) Plot of normative anorthite $(\mathrm{An})$ vs albite $(\mathrm{Ab})$ vs orthoclase $(\mathrm{Or})$ for gneisses of the Killingworth and Middletown complexes. Lithologic field boundaries from Barker (1979). All normative data were calculated using Fe $2^{+} / \mathrm{Fe}($ total $)=$ 0.9. (B) Plot of total alkalies $\left(\mathrm{Na}_{2} \mathrm{O}+\mathrm{K}_{2} \mathrm{O}\right)$ vs $\mathrm{SiO}_{2}$ for rocks of the Middletown Formation in the study area, with field boundaries from Le Maitre and others (1989). All data are expressed in weight percent. Dashed line separating alkalic and subalkalic fields from Irvine and Baragar (1971).

juxtaposed against Neoproterozoic Gondwanan basement rocks (Wintsch and others, 2005). A new interpretation for this contact is presented in the Discussion section below. 

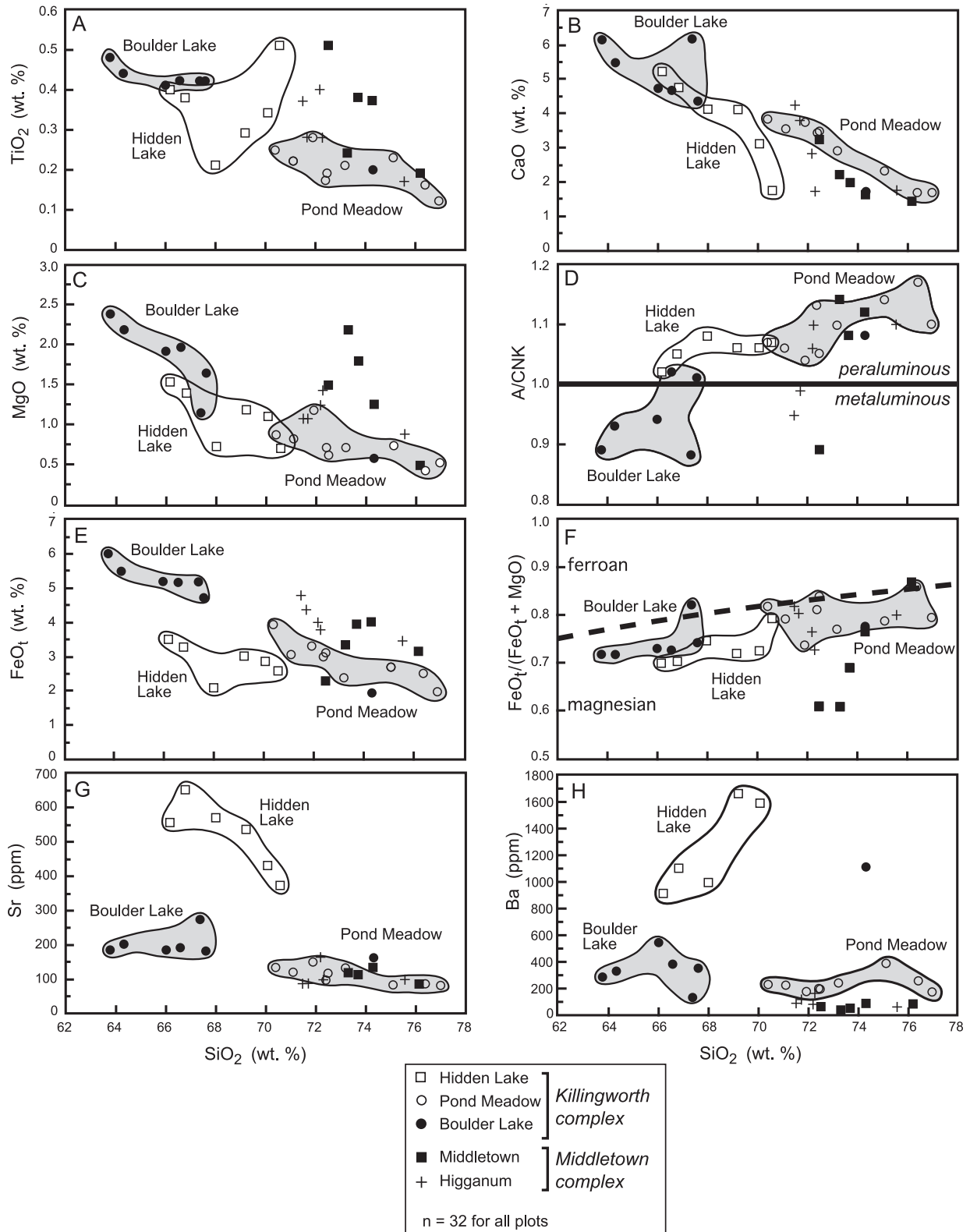

Fig. 6. Geochemical plots of whole-rock data $\left(\mathrm{SiO}_{2}\right.$ vs. various discriminants) from the Killingworth dome. (A) $\mathrm{TiO}_{2}$, (B) $\mathrm{CaO}$, (C) $\mathrm{MgO}$, (D) aluminum saturation index (A/CNK $=$ molar $\left(\mathrm{Al}_{2} \mathrm{O}_{3} /(\mathrm{CaO}+\right.$ $\left.\mathrm{Na}_{2} \mathrm{O}+\mathrm{K}_{2} \mathrm{O}\right)$ ), (E) $\mathrm{FeO}_{\mathrm{t}}$ (total iron expressed as $\mathrm{FeO}$ ), (F) $\mathrm{FeO}_{\mathrm{t}} /\left(\mathrm{FeO}_{\mathrm{t}}+\mathrm{MgO}\right),(\mathrm{G}) \mathrm{Sr}$, and $(\mathrm{H}) \mathrm{Ba}$. All data are expressed in weight percent except $\mathrm{Sr}$ and $\mathrm{Ba}$ which are expressed in parts per million. Dashed line separating the ferroan (tholeiitic) and magnesian (calc-alkaline) fields in F from Frost and others (2001).

Zircons from the Clinton Granite Gneiss (sample 5BS8.11.01; locality 1, fig. 3) are subhedral to euhedral, and medium brown. Some grains are prismatic [average length-to-width ratio $(1 / \mathrm{w})=3-4$, whereas others are more stubby $(1 / \mathrm{w}=1-2)]$. Most grains are fractured and contain numerous opaque inclusions. All zircons show fine, concentric, oscillatory zoning in cathodoluminescence (CL) (fig. 7A). Only a few 


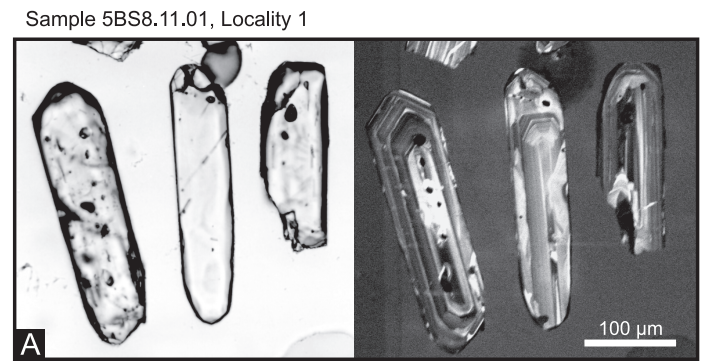

Sample Ha-1-02, Locality 2
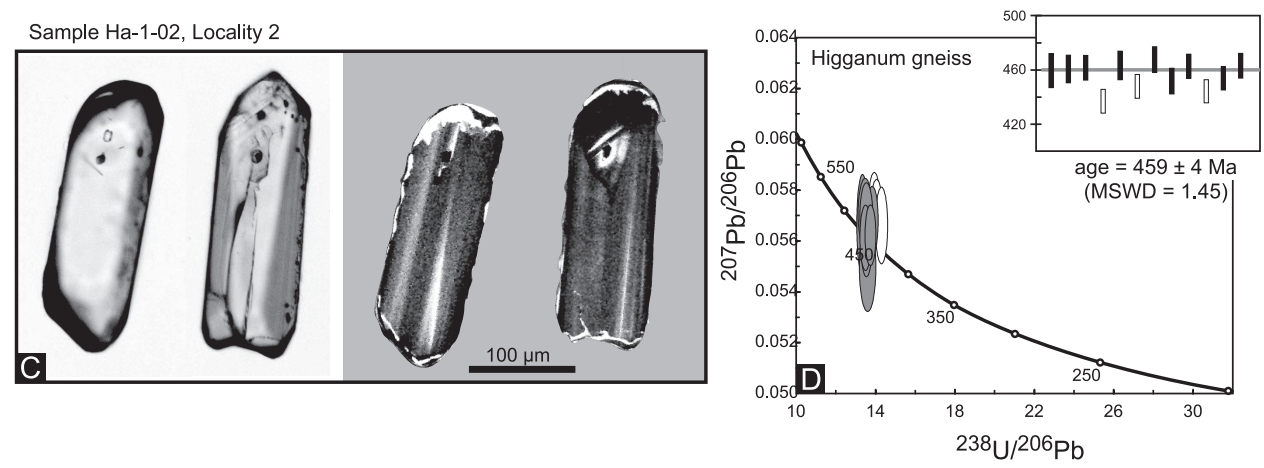

Sample 52305-1, Locality 3
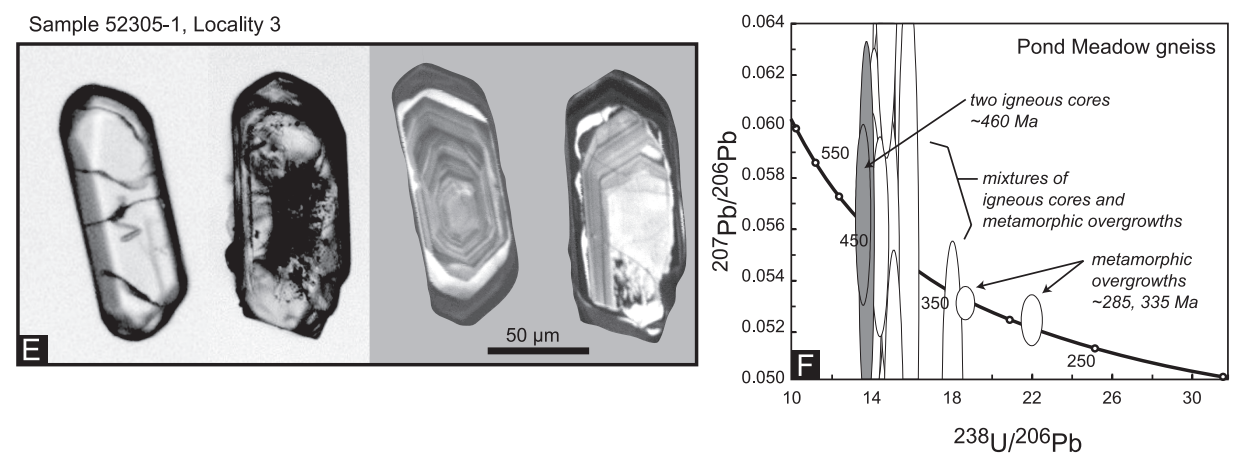

Fig. 7. Digital images (transmitted light and CL) of representative zircons and Tera-Wasserburg Concordia plots (with insets showing weighted averages of ${ }^{206} \mathrm{~Pb} /{ }^{238} \mathrm{U}$ ages) for rocks of the Killingworth complex. Only gray-filled error ellipses used in weighted average calculations here and in subsequent plots. (A-B) Clinton Granite Gneiss (sample 5BS8.11.01); (C-D) Higganum gneiss (sample Ha-1-02); (E-F) Pond Meadow gneiss (sample 52305-1).

grains have very small, dark, unzoned overgrowths. Fourteen of $17 \mathrm{U}-\mathrm{Pb}$ analyses by sensitive high resolution ion microprobe (SHRIMP) yield an age of $605 \pm 3 \mathrm{Ma}$ (fig. 7B), interpreted as the time of crystallization of the granite protolith. Two younger analyses from cores are probably due to minor $\mathrm{Pb}$ loss. One analysis on the dark (in CL) outermost portion of a grain (probably an overgrowth) yields an age of about 552 Ma.

Higganum gneiss. - The Higganum gneiss ("western gneiss" of Webster and Wintsch, 1987) crops out along the western margin of the Killingworth dome (fig. 3). Rocks of 
this unit are pale to medium gray-weathering calc-alkaline tonalitic and trondhjemitic gneisses (Webster and Wintsch, 1987), with subordinate amphibolite and biotite schist. The strongly gneissose fabric of the Higganum has destroyed primary structures; however, conformable layering of amphibolite and schist within the gneiss suggests an extrusive origin.

Zircons from a tonalitic sample of Higganum gneiss (sample Ha-1-02; locality 2, fig. 3) are prismatic, subhedral to euhedral, light brown to colorless, and contain numerous opaque inclusions. In CL, these grains show oscillatory zoning that is parallel to the crystallographic c-axis of the grains but is not concentric (fig. 7C). Also present are very small overgrowths that are black and unzoned in CL. The zircons contain relatively high concentrations of uranium (mostly $600-800 \mathrm{ppm}$ ) and have relatively high $\mathrm{Th} / \mathrm{U}(0.2-0.3$, table 2$)$, indicative of magmatic origin. U-Pb SHRIMP data (9 of 12 analyses) indicate an age of $459 \pm 4 \mathrm{Ma}$ (fig. 7D), interpreted as the time of crystallization of the volcanic protolith. The three slightly younger ages probably are due to minor $\mathrm{Pb}$ loss.

Pond Meadow gneiss.-The Pond Meadow gneiss ("eastern gneiss" of Webster and Wintsch, 1987) occurs on the southern, western, and northern flanks of the Killingworth dome (fig. 3). It is a pale-gray weathering tonalitic and trondhjemitic gneiss, and is the most sodic and least mafic of all Killingworth units (table 1; Webster and Wintsch, 1987). The gneiss is poorly to moderately foliated, coarse-grained, and commonly migmatitic (Wintsch and others, 2005), suggesting that an anatectic event was superimposed on an earlier orthogneiss.

Zircons from the Pond Meadow gneiss (samples 52305-1 and 3BS8.11.01; localities 3 and 4, respectively, fig. 3) occur as two morphologic types. Both populations are prismatic and euhedral. Most grains from sample 52305-1 are medium-brown and contain numerous cracks and opaque inclusions. CL images show that these grains are composed primarily of concentric, oscillatory-zoned cores (many of which are broken), overgrown by dark, unzoned rims (fig. 7E). In contrast, most grains from sample 3BS8.11.01 are colorless and composed of very small, partially resorbed cores and broad, patchwork-zoned mantles (fig. 8A). We dated both populations, with the intent of determining: (1) the age of the igneous protolith by analyzing the oscillatory-zoned cores, and (2) the age of anatexis/metamorphism by analyzing the broad, patchworkzoned mantles.

Two analyses of oscillatory-zoned cores from sample $52305-1$ yield ${ }^{206} \mathrm{~Pb} /{ }^{238} \mathrm{U}$ ages of $\sim 456$ to $462 \mathrm{Ma}$ ( $\mathrm{Th} / \mathrm{U}$ of about 0.3 , table 2 ), interpreted as the approximate time of igneous emplacement (fig. 7F). Two analyses of overgrowths from this sample yield ages of $\sim 335$ and $\sim 285 \mathrm{Ma}(\mathrm{Th} / \mathrm{U}<0.02)$, interpreted as times of metamorphism. Several other analyses, with intermediate ages (about 418 - $448 \mathrm{Ma}$ ) and high, igneous-type $\mathrm{Th} / \mathrm{U}(0.24-0.44)$, probably result either from analysis of mixed core and rim, or $\mathrm{Pb}$ loss from highly cracked grains. These dates have no age significance.

Patchwork-zoned mantles from zircons in sample 3BS8.11.01 have low $\mathrm{Th} / \mathrm{U}$ $(<0.04)$, indicative of metamorphic origin. Ten analyses yield a weighted average age of $335 \pm 2 \mathrm{Ma}$ (fig. 8B). Three analyses are slightly younger ( $\sim 325$ and $300 \mathrm{Ma})$ and one analysis is slightly older $(\sim 345 \mathrm{Ma})$. In addition, one oscillatory-zoned core yielded an age of about $460 \mathrm{Ma}$. We conclude from results from both samples that the Pond Meadow gneiss crystallized at about $460 \mathrm{Ma}$ and was metamorphosed to high-grade, probably anatectic conditions at about $335 \mathrm{Ma}$. We see no evidence for a metamorphic event older than about $335 \mathrm{Ma}$. Limited data suggest subsequent metamorphic zircon growth as young as about $300 \mathrm{Ma}$.

Boulder Lake gneiss. - The belt of Boulder Lake gneiss, named by Lundgren and Thurell (1973) for rocks in the Clinton quadrangle, has been extended eastward into 


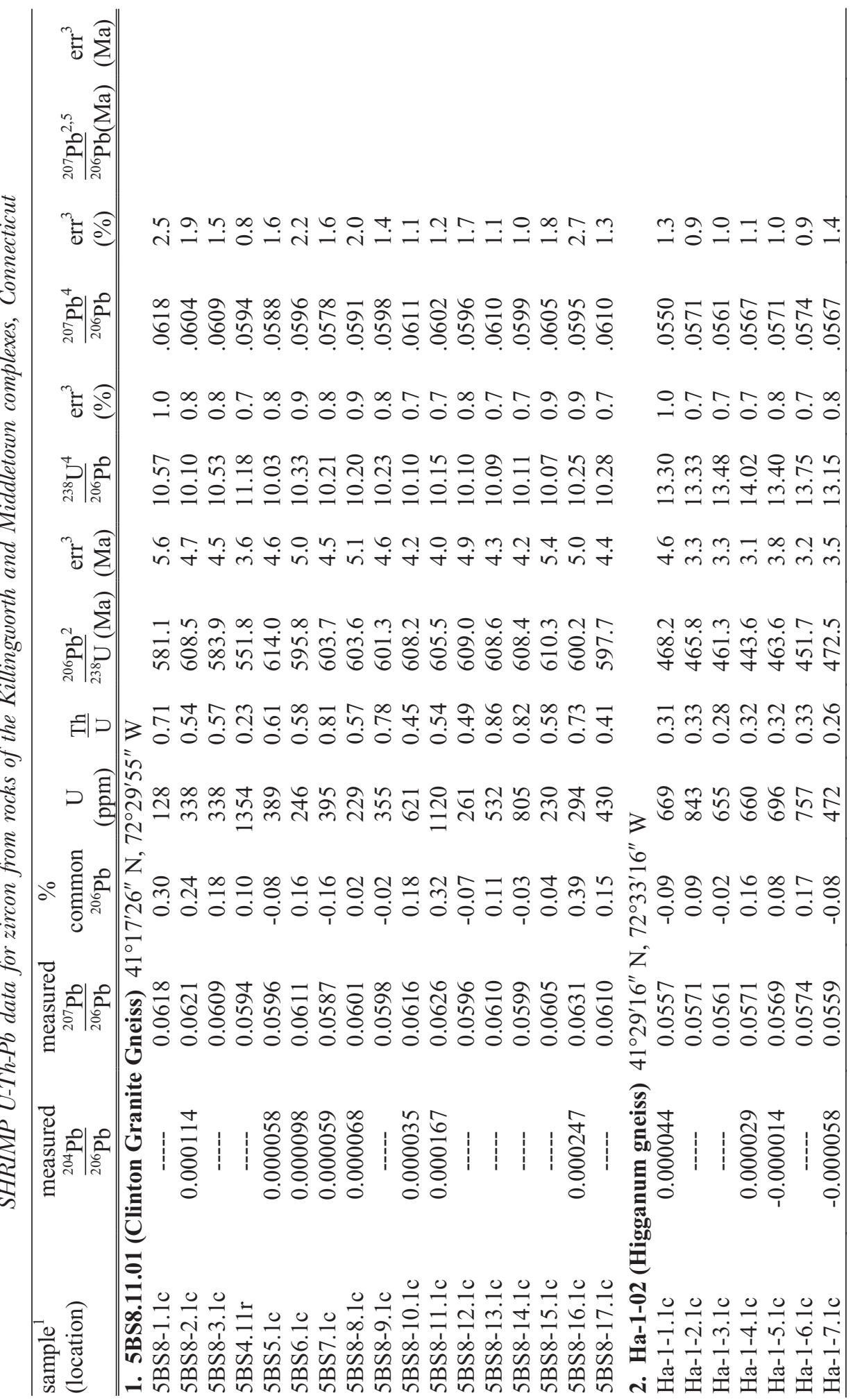




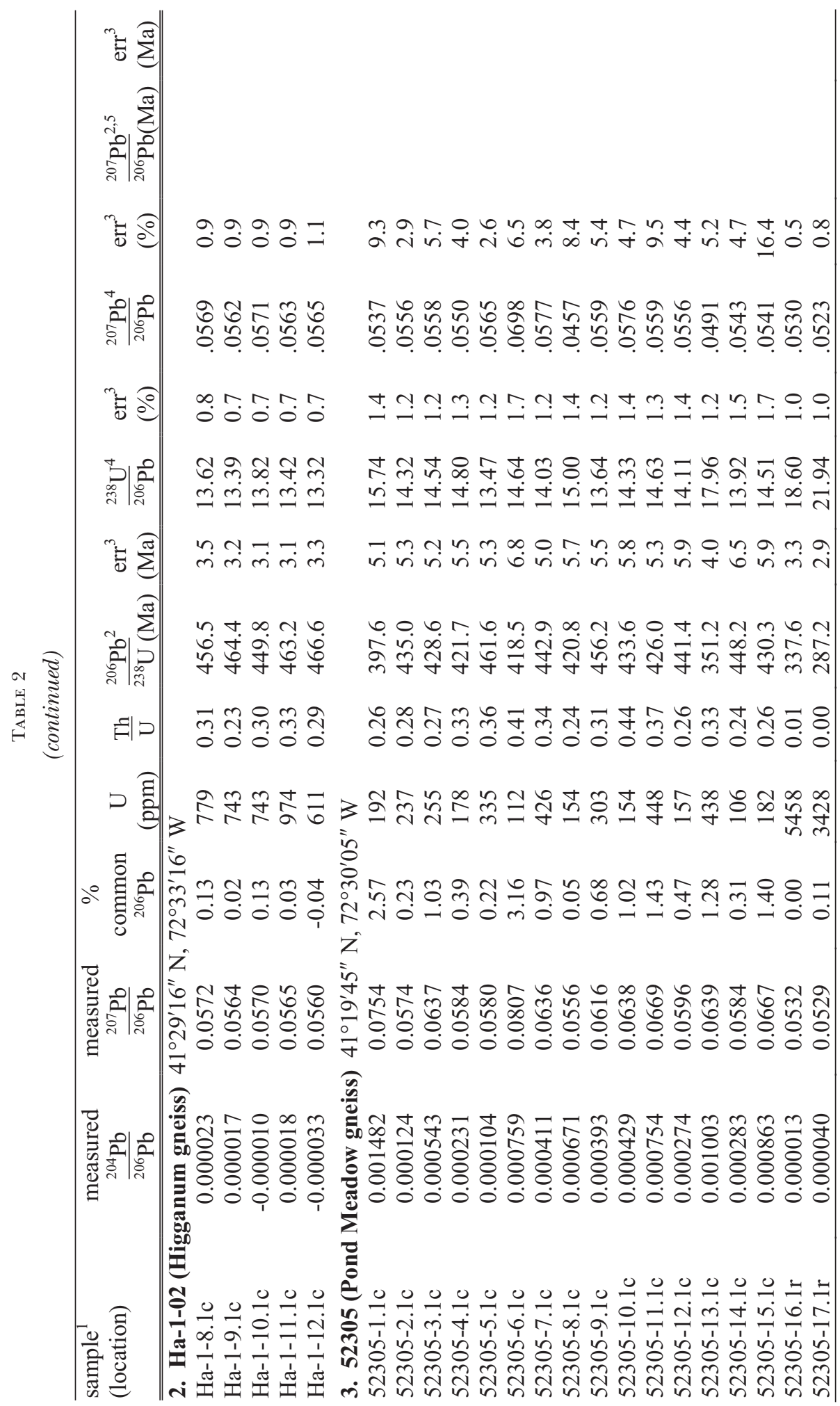




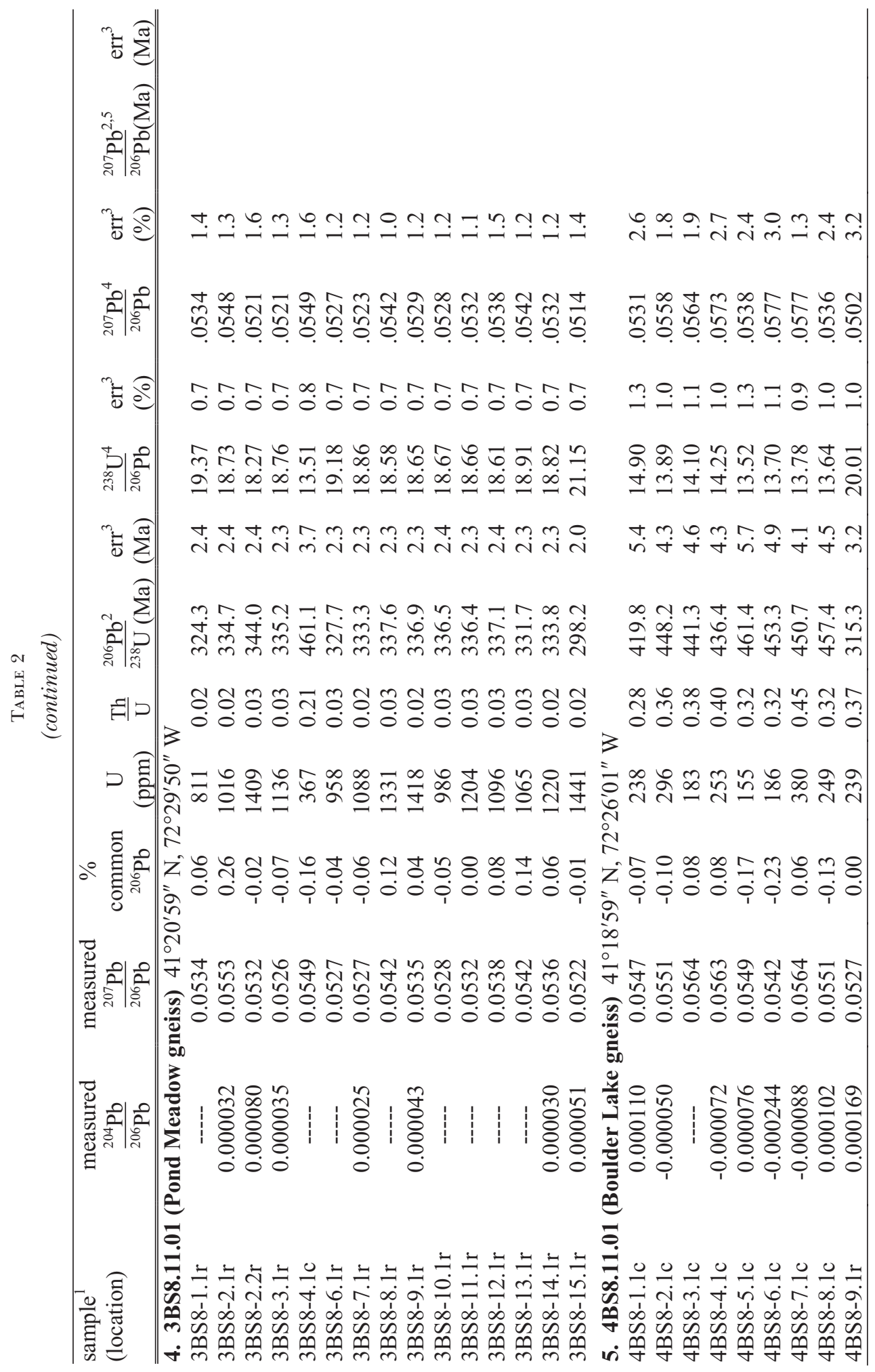


south-central Connecticut: Implications for the tectonic evolution

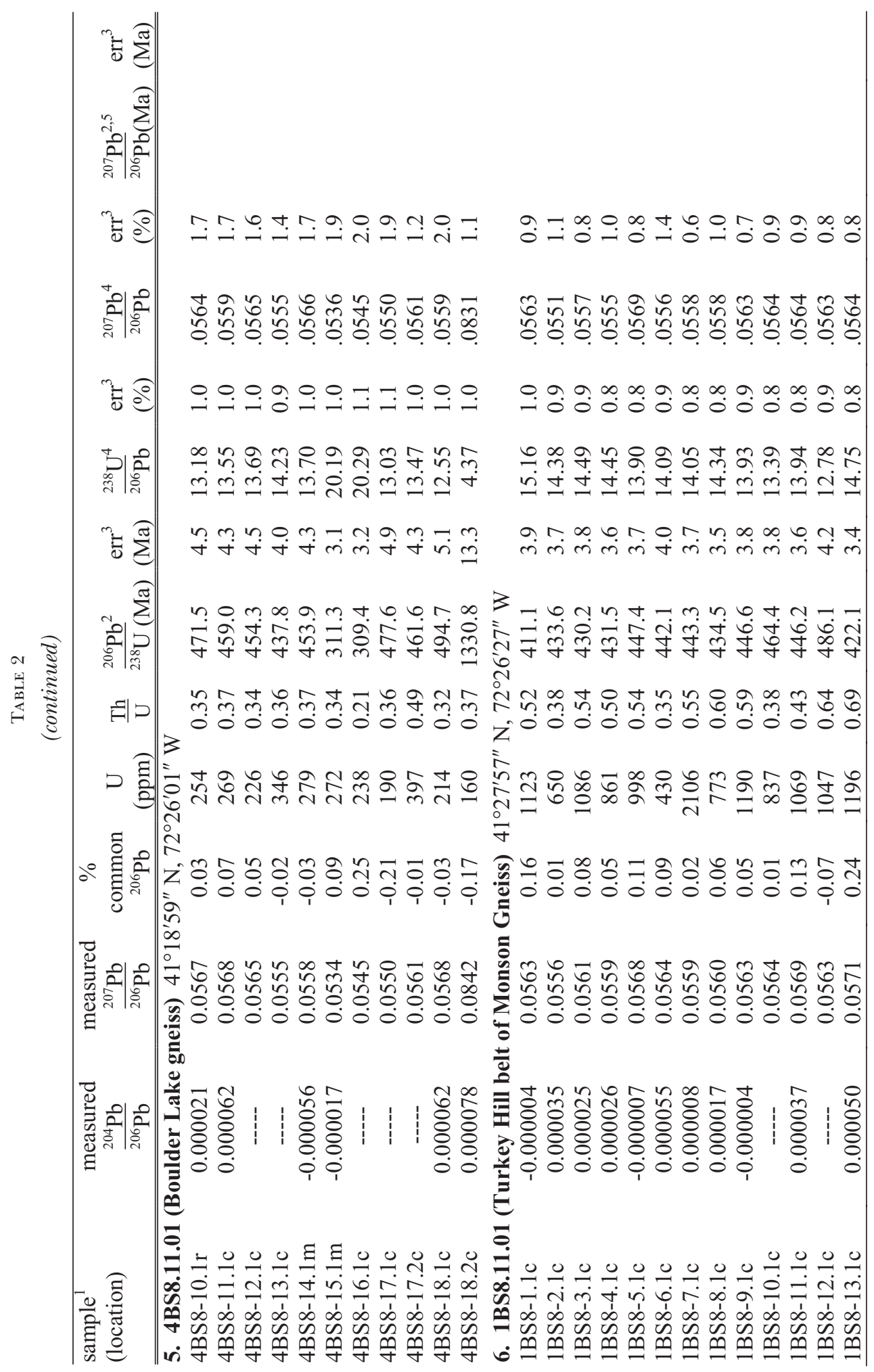




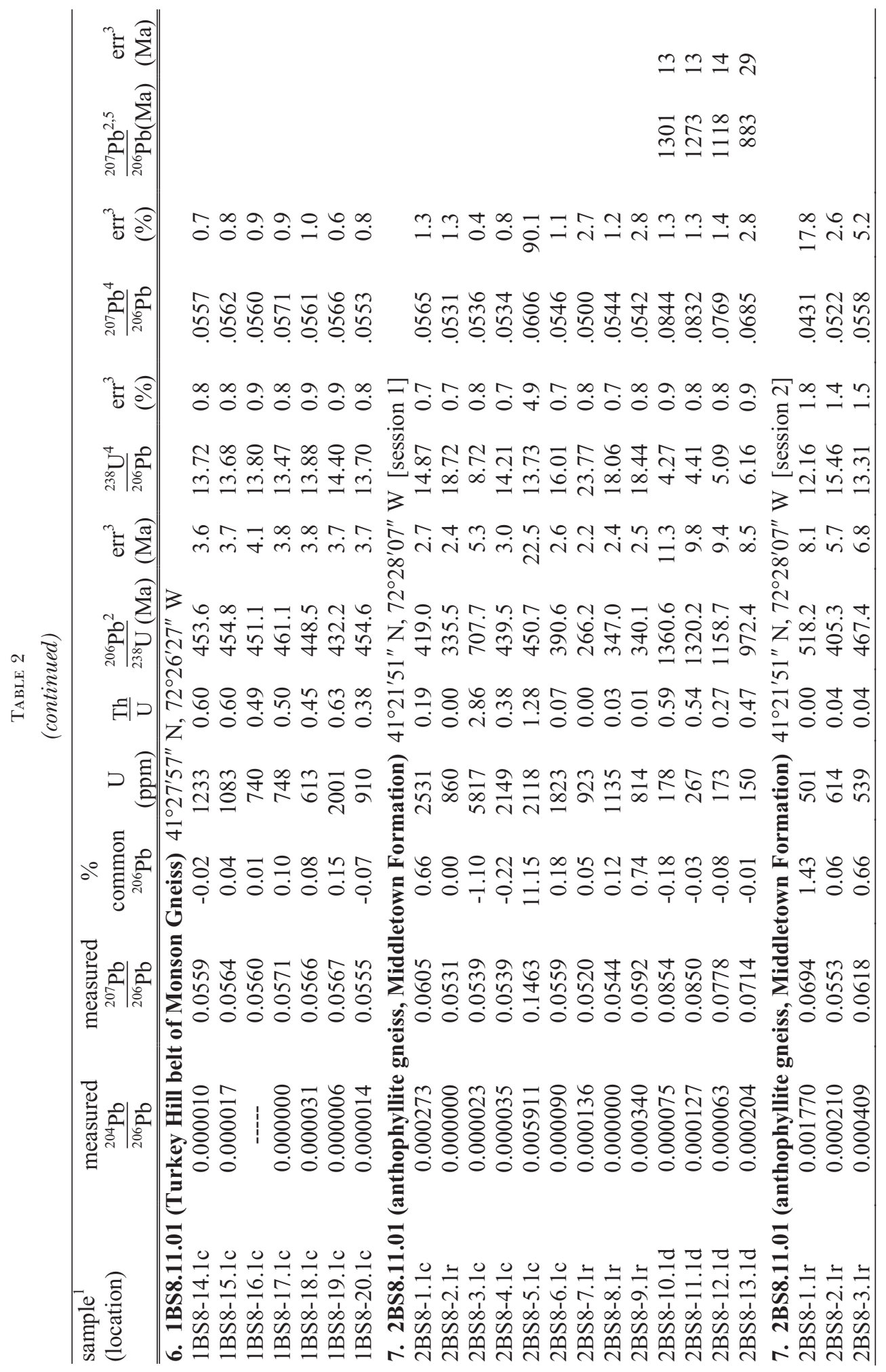




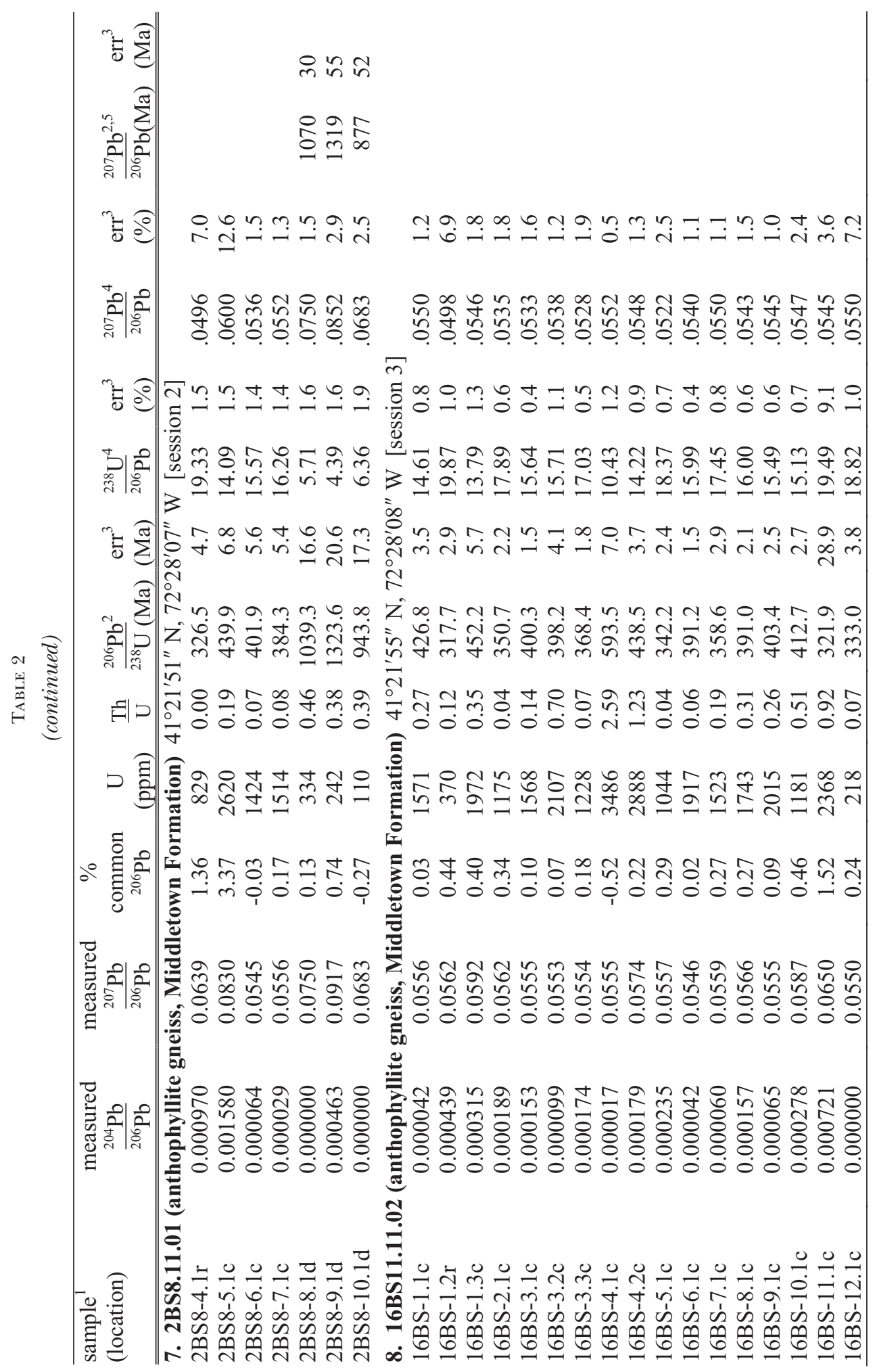




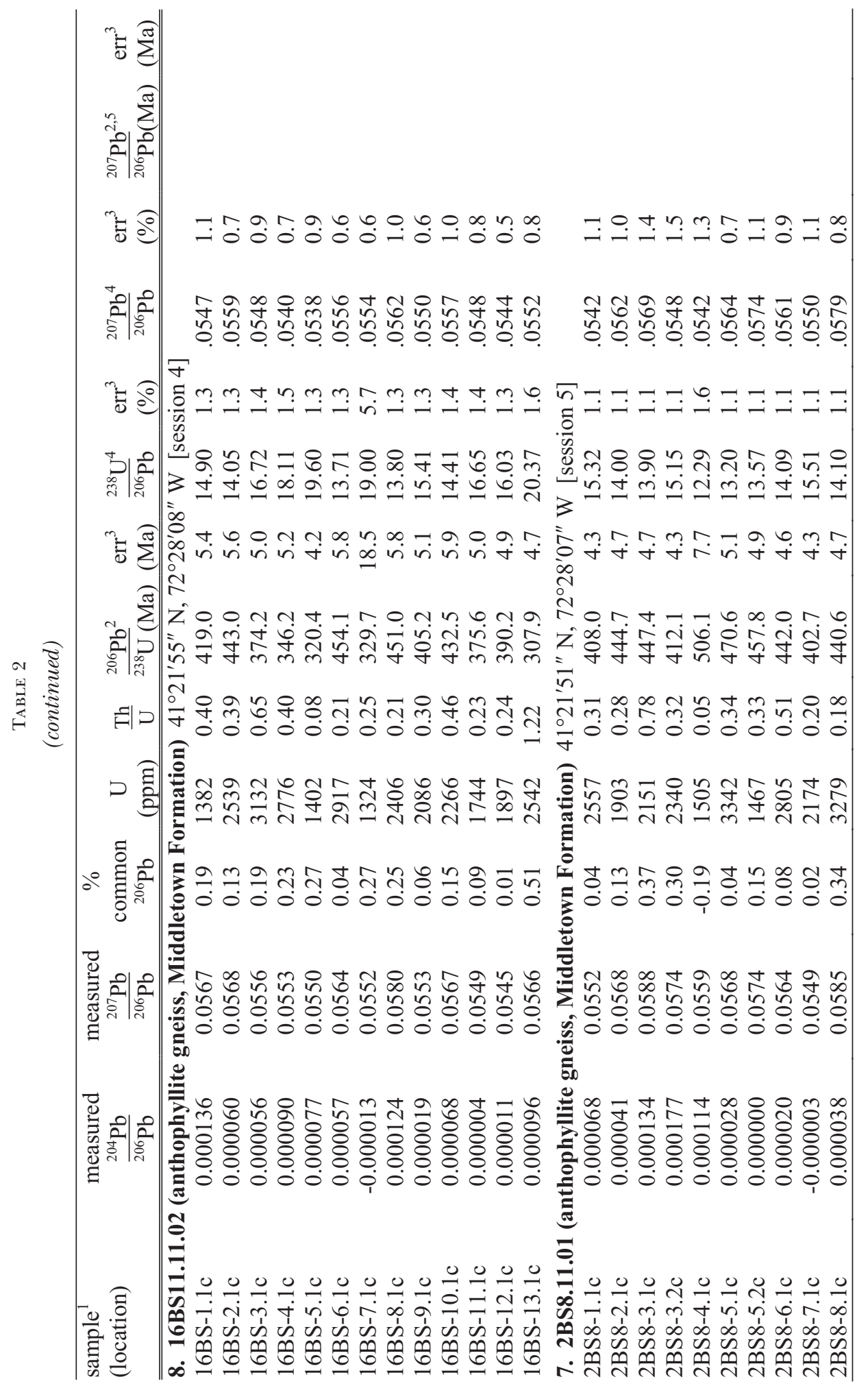


south-central Connecticut: Implications for the tectonic evolution

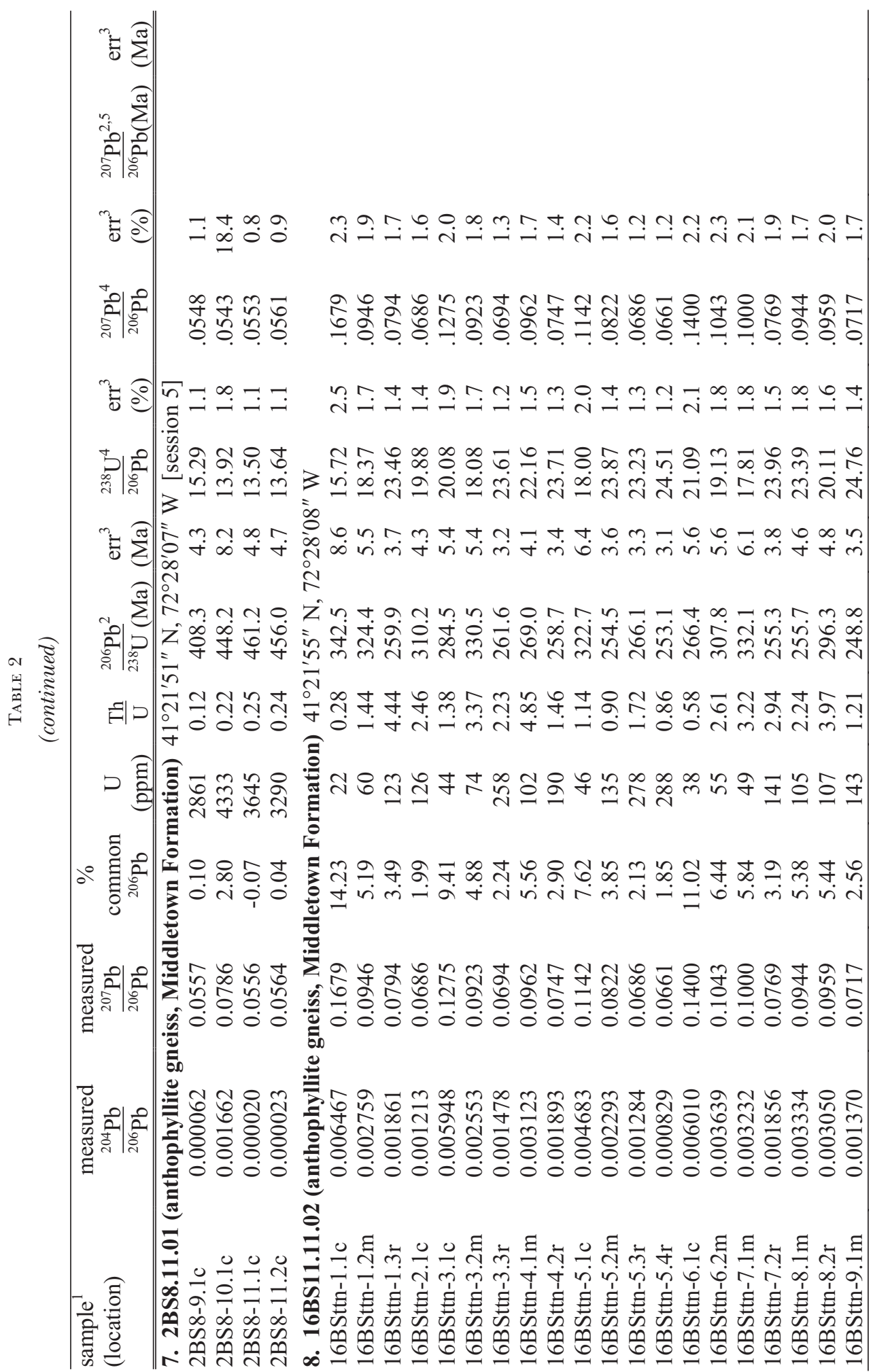


そี

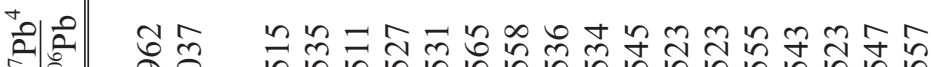

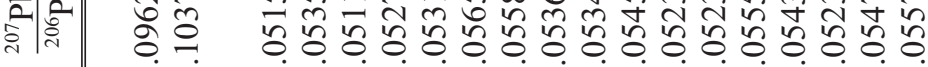

"⿱⿻一⿻一㇉丶丶

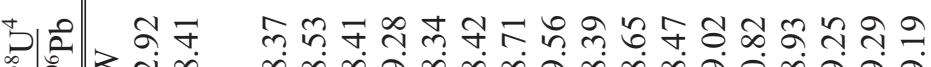

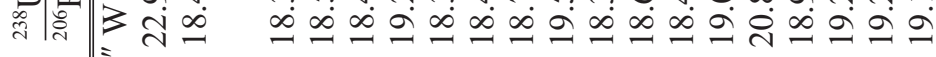

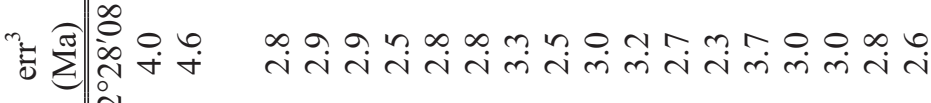

ส

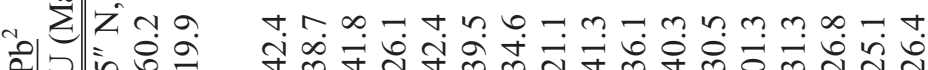

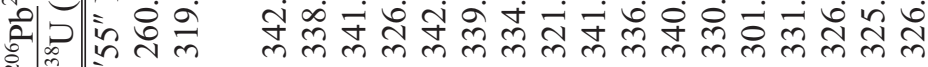
चे

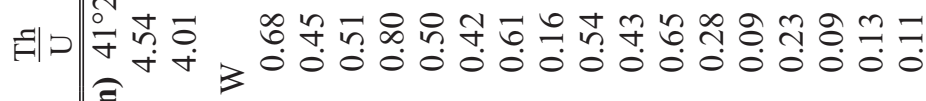

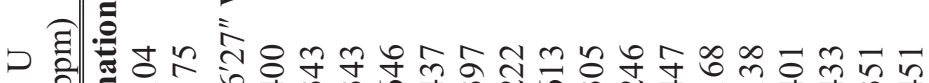

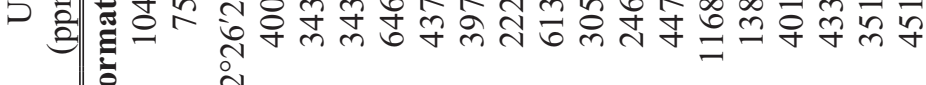
กิ

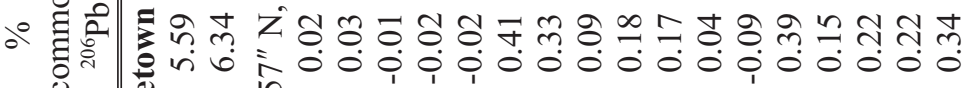

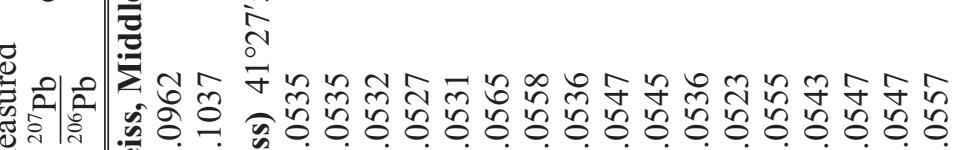
$\Xi$

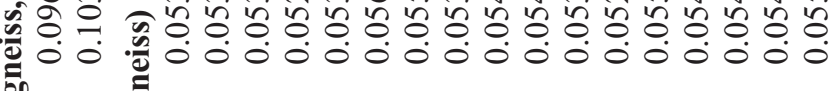

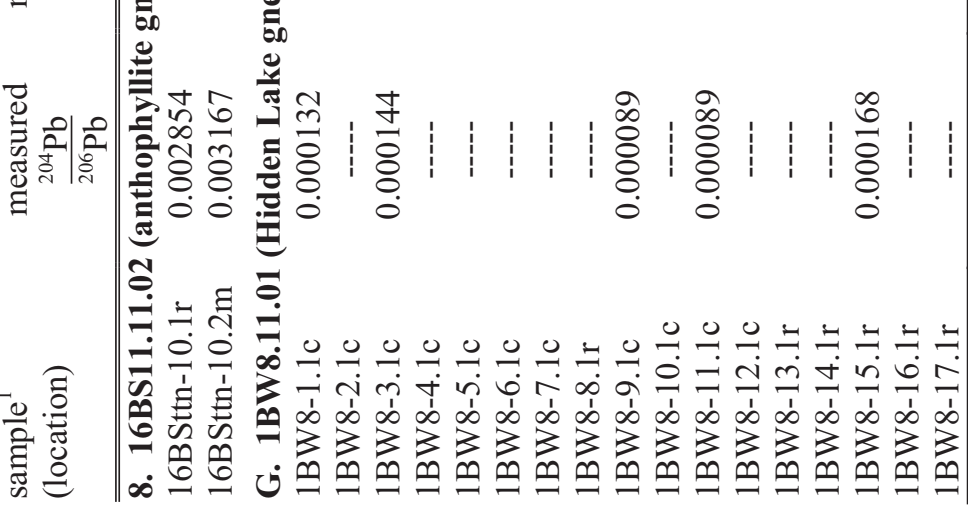




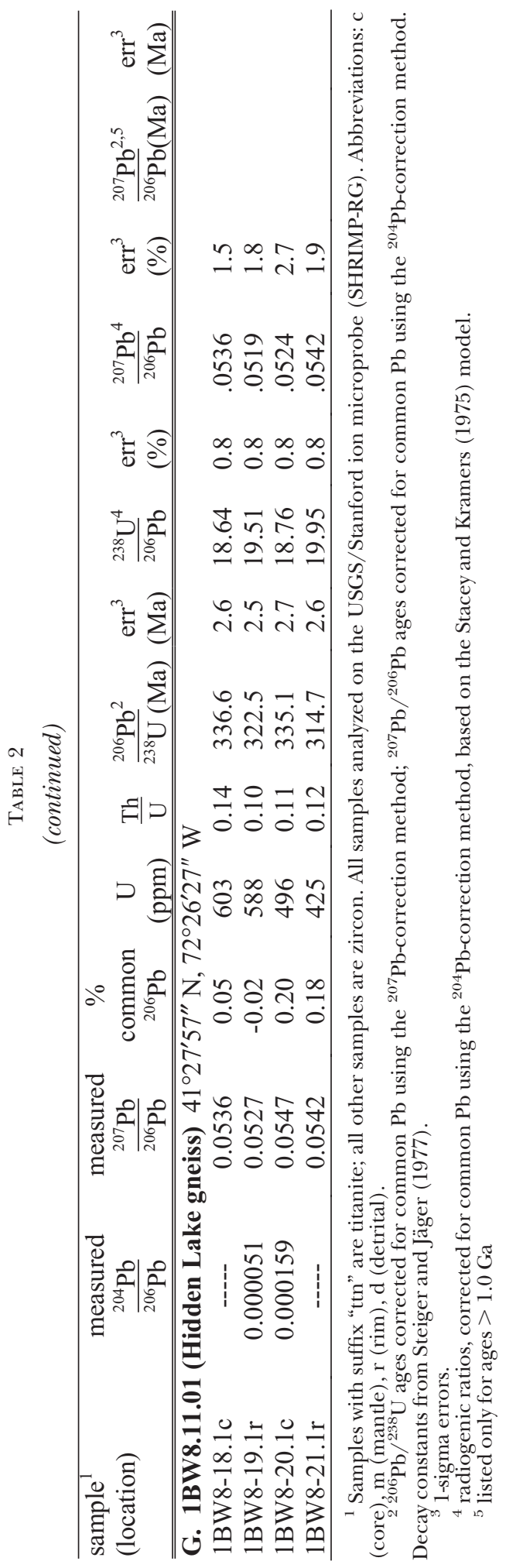



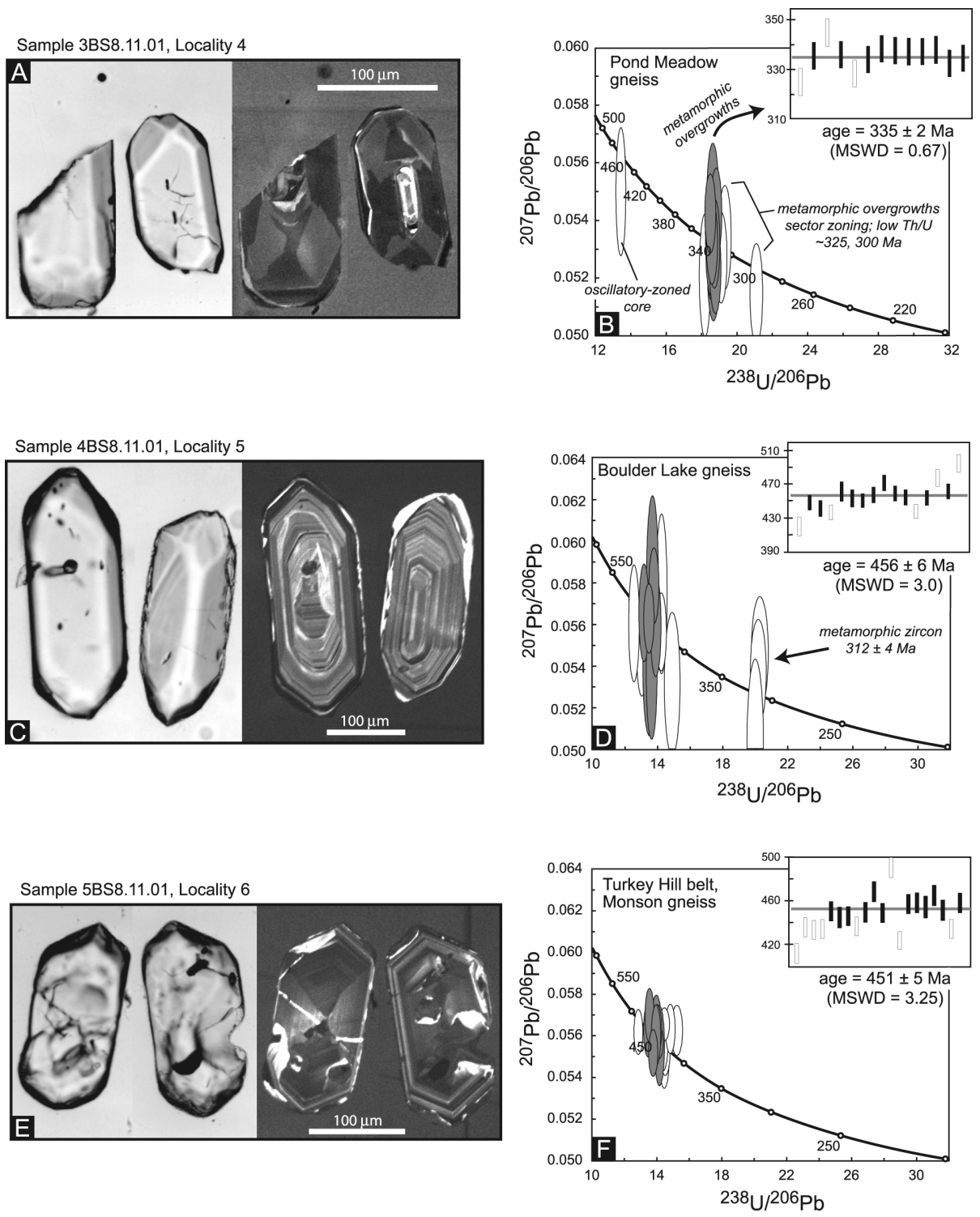

Fig. 8. Digital images (transmitted light and CL) of representative zircons and Tera-Wasserburg Concordia plots (with insets showing weighted averages of ${ }^{206} \mathrm{~Pb} /{ }^{238} \mathrm{U}$ ages) for rocks of the Killingworth dome. (A-B) Pond Meadow gneiss (sample 3BS8.11.01); (C-D) Boulder Lake gneiss (4BS8.11.01); (E-F) Turkey Hill belt of Monson Gneiss (1BS8.11.01)

the Essex quadrangle (Wintsch, 1994). It occurs south of the Pond Meadow gneiss and north of the Clinton Granite Gneiss (fig. 3). The Boulder Lake is a medium- to dark-gray, weakly foliated, generally unlayered, medium-grained tonalitic pluton characterized by the common occurrence of mafic and calc-silicate inclusions (Lundgren and Thurrell, 1973). Primary igneous structures are not preserved where strain is high, such as along its southern fault contact with the Clinton Granite Gneiss (Wintsch and others, 2005). Whole-rock compositions show the protolith to be zoned in normative 
anorthite content, with a more sodic interior, and more calcic margin (Wintsch and others, 1990).

Zircons from the Boulder Lake gneiss (sample 4BS8.11.01; locality 5, fig. 3) are prismatic, euhedral, and light brown. Most grains show fine concentric, oscillatory zoning in CL (fig. 8C), and some grains have narrow dark or white (in CL), unzoned overgrowths. U contents of Boulder Lake zircons are moderate $(150-400 \mathrm{ppm}$, table 2 ); $\mathrm{Th} / \mathrm{U}$ is 0.2 to 0.4 , typical of igneous origin. Eleven of 16 analyses of the oscillatory-zoned portions of the grains yield an age of $456 \pm 6 \mathrm{Ma}$, interpreted as the time of crystallization of the tonalitic protolith (fig. 8D). Two analyses are older (478 and $495 \mathrm{Ma}$ ). Another core, with an irregular rounded boundary and oscillatory zoning truncated at the interface with the igneous mantle, yielded an age of $1.33 \mathrm{Ga}$, indicating possible Grenville inheritance. Several ages younger than 450 Ma probably are due to Pb-loss, as these were obtained from oscillatory-zoned mantles. Three metamorphic overgrowths yield an age of $\sim 312 \mathrm{Ma}$.

Turkey Hill belt of Monson Gneiss. - The Turkey Hill belt of Monson Gneiss (Lundgren, 1963) occurs in a narrow, north-northwest-trending belt of orthogneiss that crops out on the east side of the Killingworth dome in the eastern part of the study area (fig. 3). Rodgers (1985) showed this belt as a continuous unit that extends north into Massachusetts toward rocks mapped as Monson Gneiss, whereas Webster and Wintsch (1987) grouped these rocks with their "eastern gneiss." These medium- to coarsegrained rocks include granitic gneiss, tonalitic gneiss, amphibolite, and dunite (Wintsch, 1994). The rock sampled for geochronology is a tan, strongly foliated, medium- to coarse-grained, granitic gneiss. Although originally correlated with other plagioclase gneisses in the area (Rodgers, 1985), this belt of rock was shown by Wintsch (1994) not to be part of the Killingworth complex. Consequently, we dated this sample of Monson Gneiss, but do not include this lithology in our geochemical study.

Zircons from the Turkey Hill belt of Monson Gneiss (sample 1BS8.11.01; locality 6, fig. 3) are euhedral and medium brown; most contain numerous cracks. CL images show fine oscillatory zoning in broad cores and coarse oscillatory zoning in the outer portions of the grains (fig. 8E). Many grains are invaded by wisps of white (in CL) material, suggestive of subsequent metamorphic dissolution and replacement. The zircons have moderately high $\mathrm{U}$ contents $(600-2100 \mathrm{ppm})$ and $\mathrm{Th} / \mathrm{U}$ of 0.3 to 0.6 (table 2). Twelve of 20 analyses form a coherent group with an age of $451 \pm 5 \mathrm{Ma}$ (fig. $8 \mathrm{~F}$ ), interpreted as the time of crystallization of the igneous protolith. One analysis is older ( $\sim 486 \mathrm{Ma})$ and may reflect derivation of this gneiss from slightly older Ordovician source rocks possibly related to the Bronson Hill terrane. Younger ages $(\sim 410-$ $435 \mathrm{Ma}$ ) probably are due to $\mathrm{Pb}$ loss from damaged, fractured grains, and thus are considered to be geologically meaningless.

Middletown Formation. - The Middletown and Collins Hill formations of Rodgers (1985) crop out on the outer margins of the Killingworth dome, except on the southeast side (fig. 3). These map units include biotite schist, plagioclase gneiss, anthophyllite gneiss, amphibolite, and calc-silicate schist (Bernold, 1976), a lithologic package suggesting a volcanic-sedimentary protolith. The Middletown Formation is considered to be primarily metavolcanic, whereas the Collins Hill Formation is mostly of sedimentary origin (Lundgren, 1979). These two units are interlayered; distinction between the two formations is based on proportion of inferred igneous or sedimentary components. On the west side of the Killingworth dome, the Middletown Formation is structurally above the Higganum gneiss with a gradational contact. The Higganum is primarily a felsic rock with lesser amounts of amphibolite and schist, whereas the Middletown is primarily an amphibolite with lesser amounts of meta-diorite and schist. The protoliths of both units probably were volcanic. Anthophyllite gneiss of the 
Middletown Formation is medium-gray, strongly foliated, strongly lineated, welllayered, medium- to coarse-grained plagioclase gneiss. The occurrence within the anthophyllite gneiss of a minor population of rounded zircon grains interpreted as detrital in origin supports the suggestion of Lundgren (1979) that the protolith of the anthophyllite gneiss was an extrusive rock. Collectively, the Middletown and Collins Hill formations and the Higganum gneiss constitute our Middletown complex.

Zircons from the anthophyllite gneiss (samples 2BS8.11.01 and 16BS11.11.02; localities 7 and 8, respectively, fig. 3) have a very unusual morphology. Almost all grains are dark brown and anhedral with irregular, amoeboid shapes. In CL, they show dark, mottled textures with sparse, very dark spots irregularly overgrown by pale rims (fig. 9A). In back-scattered electron (BSE) imaging, most grains contain small, randomly distributed, very bright spots identified as thorite (using XRF energy-dispersive analysis). The white (in CL) rim material commonly invades the grains. Consequently, there are very few pristine, homogeneous areas large enough to accommodate a SHRIMP analysis without contamination by an adjacent zone. We suggest that the unusual anhedral, mottled grains are primarily igneous in origin, with discontinuous metamorphic overgrowths. A second population of zircon (less than $1 \%$ of the total) also occurs in the anthophyllite gneiss. These grains are roughly equant, rounded, light brown to colorless, and have a variety of types of oscillatory zoning, all of which are truncated at grain boundaries (fig. 9A). As shown by the U-Pb age data below, we interpret these rounded grains to be detrital in origin.

By imaging in both CL and BSE, and examining thousands of grains during five separate SHRIMP sessions, we were able to obtain sufficient U-Pb data to have confidence in assigning an age to this rock. The anhedral, mottled grains have high $\mathrm{U}$ contents $(800-3600 \mathrm{ppm})$ and igneous-type $\mathrm{Th} / \mathrm{U}$ ratios of 0.2 to 0.6 (table 2$)$. The light-colored (in CL) overgrowths have lower U (mostly $800-1200 \mathrm{ppm}$ ) and very low $\mathrm{Th} / \mathrm{U}(0-0.04)$ typical of zircons of metamorphic origin. Rounded, oscillatory-zoned grains interpreted as detrital have moderate $\mathrm{U}$ contents $(100-300 \mathrm{ppm})$ and $\mathrm{Th} / \mathrm{U}$ of 0.2 to 0.6 typical of igneous origin. Isotopic data from 67 analyses ( 5 analytical sessions) from all grain types yield a broad spectrum of ages (fig. 9B). Thirteen analyses (from 4 sessions) of homogeneous core zones result in a coherent group of data with an age of $449 \pm 4$ Ma (fig. 9C). Six overgrowths yield ages of about 350 to $320 \mathrm{Ma}$; one other overgrowth is about $270 \mathrm{Ma}$. Many more analyses yielded intermediate ages, and probably represent the result of mixing of Ordovician core regions with Carboniferous overgrowths. Zircons interpreted as detrital in origin have much older ages, between about 0.9 to $1.3 \mathrm{Ga}$ (fig. 9B).

Titanite from the anthophyllite gneiss occurs as light-brown to yellowish, anhedral grains. BSE imaging shows that many are complexly zoned, with dark (that is, relatively low-U) cores and mantles overgrown by white to light gray (that is, relatively high-U) rims (fig. 9D). A few cores display oscillatory zoning that reflects crystal faces. Titanite cores contain about 20 to 135 ppm U, whereas the rims contain about 100 to $290 \mathrm{ppm}$. All isotopic analyses indicate the presence of a significant common $\mathrm{Pb}$ component (table 2). Thus, U-Pb ages are determined by calculating regressions through the isotopic data (uncorrected for common $\mathrm{Pb}$ ) to determine concordia intercept ages of $304 \pm 9$ and $249 \pm 4$ Ma for the cores and rims, respectively (fig. 9E). We suggest that these ages record the times of titanite growth during high-grade, and locally anatectic, episodes of Alleghanian metamorphism.

Hidden Lake gneiss. - The Hidden Lake gneiss is located in the core of the Killingworth dome (fig. 3). These rocks contain relatively calcic plagioclase (Mikami and Digman, 1957), low mafic mineral content and shallow-dipping foliations (Lundgren and Thurrell, 1973), and distinctively high $\mathrm{Al}_{2} \mathrm{O}_{3}, \mathrm{Sr}$, and $\mathrm{Ba}$ contents (figs. 6G 


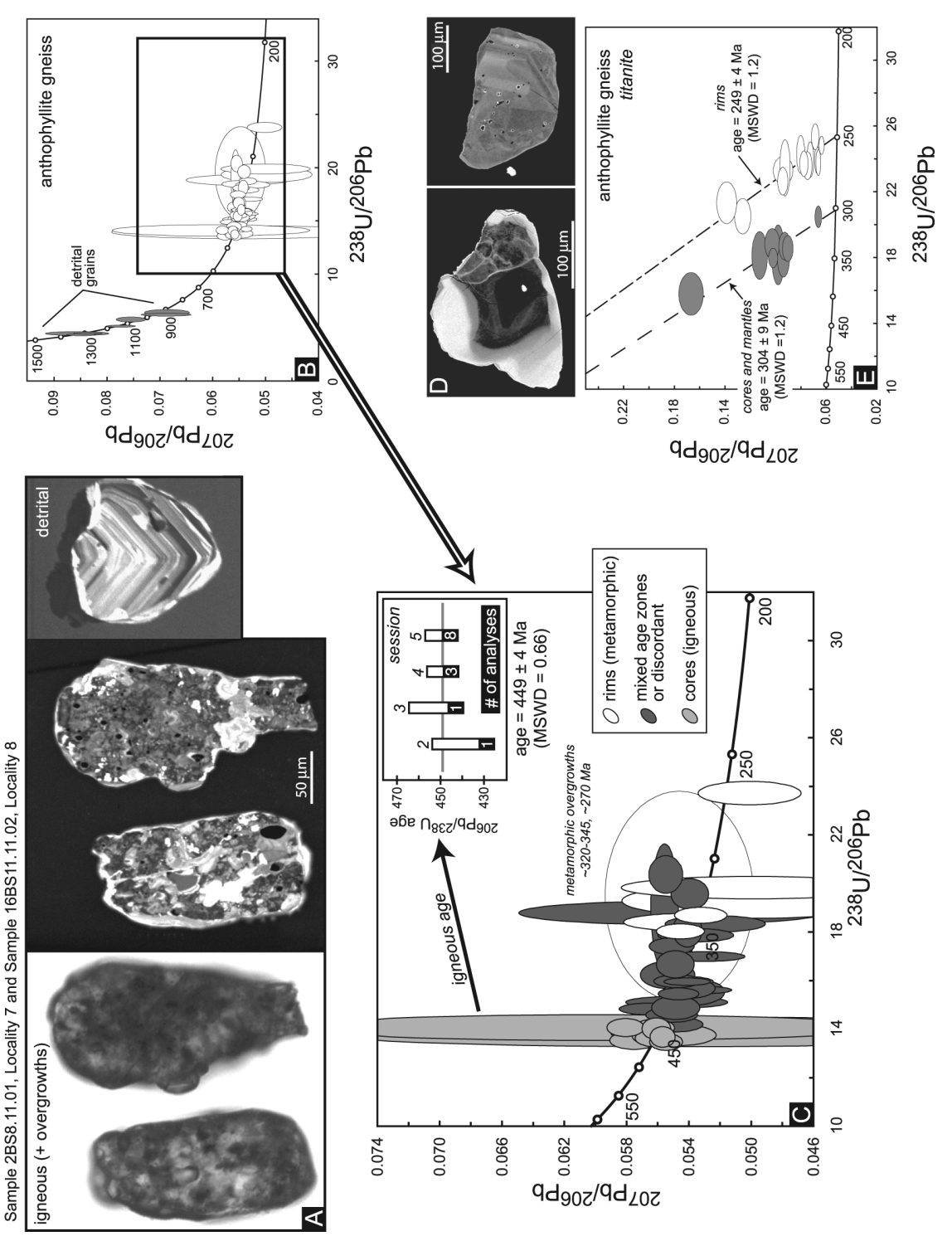

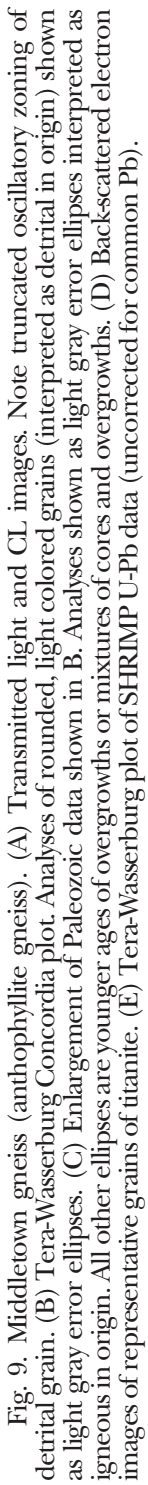



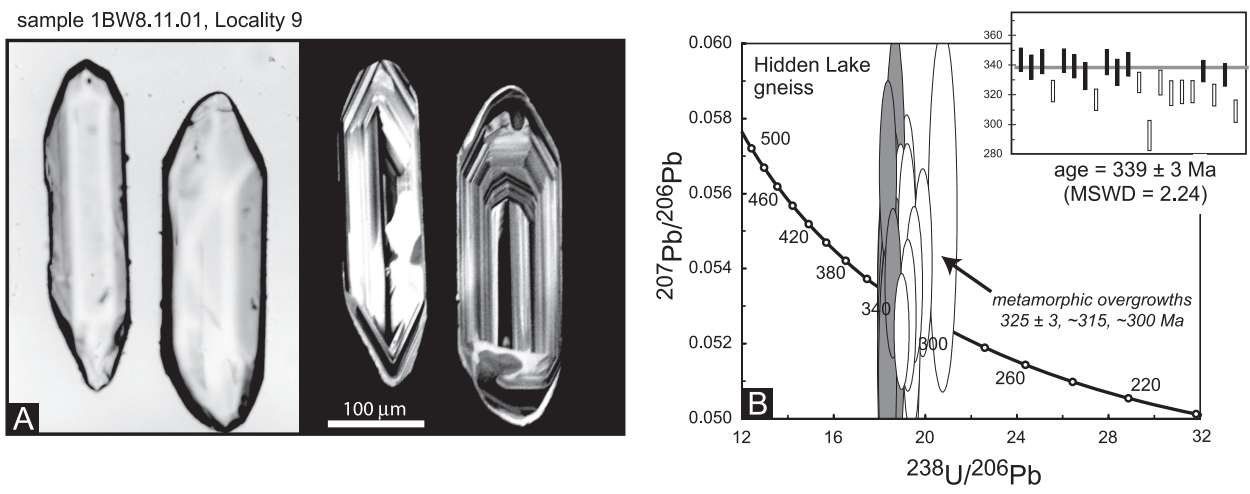

Fig. 10. Digital images (A, transmitted light and CL) of representative zircons and Tera-Wasserburg Concordia plot (B, with insets showing weighted averages of ${ }^{206} \mathrm{~Pb} /{ }^{238} \mathrm{U}$ ages) for Hidden Lake gneiss (sample 1BW8.11.01).

and $6 \mathrm{H}$; Webster and Wintsch, 1987). This unit is typically composed of light- to medium-gray, weakly foliated and generally unlayered, medium- to coarse-grained tonalitic gneiss and granofels. Chemical and modal analyses confirm that the Hidden Lake gneiss is a calc-alkaline meta-tonalitic pluton, zoned with an increasing normative anorthite content toward the core, and low amphibole content (fig. 4; Webster and Wintsch, 1987).

Zircons from the Hidden Lake gneiss (sample 1BW8.11.01; locality 9, fig. 3) are generally euhedral and prismatic, with few inclusions. All grains show fine concentric, oscillatory zoning in CL; many grains have dark, unzoned tips (fig. 10A) that locally invade deep into the cores. The oscillatory-zoned portions contain moderate amounts of $\mathrm{U}$ (about $200-400 \mathrm{ppm})$ and relatively high $\mathrm{Th} / \mathrm{U}(0.5-0.8$, table 2$)$ typical of magmatic zircons, whereas the tips have higher U-contents (mostly $400-700 \mathrm{ppm}$ ) and have much lower Th/U $(0.09-0.14)$ typical of metamorphic zircons (Hoskin and Schaltegger, 2003). Eleven analyses of the oscillatory-zoned interiors of these grains yield an age of $339 \pm 3 \mathrm{Ma}$ (fig. 10B), interpreted as the time of crystallization of the igneous protolith of this gneiss. Overgrowths yield a range of ages, including $325 \pm 3$ Ma ( 6 analyses) and $\sim 315$ and $\sim 300 \mathrm{Ma}$ ( 1 analysis each), dating times of metamorphic overprinting. This metamorphism and associated deformation produced a moderate foliation and compositional banding that dips gently north-northwest.

Summary.-Igneous protoliths of three orthogneisses in the Killingworth dome (Higganum, Pond Meadow, and Boulder Lake), crystallized in the Middle to Late Ordovician (approximately $455-460 \mathrm{Ma}$ ). Due to the strong metamorphic overprint and occurrence of interlayered amphibolite of indeterminate origin, it is unclear whether the protoliths of the Higganum and Pond Meadow gneisses were intrusive or extrusive. The homogeneous character and abundant xenoliths within Boulder Lake gneiss suggest that it is plutonic in origin. The Turkey Hill belt of Monson Gneiss (probably intrusive) and Middletown Formation (probably extrusive) are slightly younger (Late Ordovician, about $450 \mathrm{Ma}$ ). Hidden Lake gneiss, in the core of the Killingworth dome, was emplaced in the Mississippian (339 $\pm 3 \mathrm{Ma})$. The Pond Meadow gneiss was thoroughly migmatized at about this time, as shown by the occurrence of extensive zircon overgrowths dated at $335 \pm 2 \mathrm{Ma}$. The Clinton Granite Gneiss, crystallized at about $605 \mathrm{Ma}$, and represents Gondwanan basement structurally below, and in fault contact with, the Boulder Lake gneiss. 
Zircon overgrowths in several samples record late Paleozoic thermal events at about 325, 315, 300, and $270 \mathrm{Ma}$. Ages of titanite in the Middletown anthophyllite gneiss corroborate high-grade metamorphic conditions at about $300 \mathrm{Ma}$ and $250 \mathrm{Ma}$.

\section{$\mathrm{Pb}, \mathrm{Nd}$, and Sr Isotopic Data}

Samples collected for whole-rock chemical analysis were also analyzed for $\mathrm{Pb}, \mathrm{Sr}$, and $\mathrm{Nd}$ isotopes (tables 3 and 4). Procedures for isotopic analysis are discussed in the Appendix. Two analyses of $\mathrm{Sr}$ isotopes corrected to impossibly low initial values, probably due to preferential loss of radiogenic ${ }^{87} \mathrm{Sr}$ from a high $\mathrm{Rb} / \mathrm{Sr}$ phase such as biotite during late Paleozoic metamorphism. Thus, all $\mathrm{Sr}$ isotopic data are considered to possibly have been affected by metamorphism and are not discussed further. However, because the estimated amount of loss of radiogenic ${ }^{87} \mathrm{Sr}$ is less than 1 percent of the total $\mathrm{Sr}$, concentrations of $\mathrm{Sr}$ used for trace element discrimination diagrams and discussions of geochemical and petrologic processes are representative of the rock chemistry.

$\mathrm{Pb}$ isotopic data for whole-rock samples from five units of the Killingworth and Middletown complexes plot near and above the average growth curve of Stacey and Kramers (1975) (fig. 11A). Fields of data for Pond Meadow, Boulder Lake, and Hidden Lake gneisses, and all but one analysis of the Middletown Formation mostly overlap. Note that sample 14J (Hidden Lake gneiss, table 3) has anomalously high Pb isotopic ratios and has been excluded from all plots. The field of $\mathrm{Pb}$ isotopic data for the Higganum gneiss is distinctly more radiogenic in ${ }^{207} \mathrm{~Pb} /{ }^{204} \mathrm{~Pb}$, as is one analysis of anthophyllite gneiss of the Middletown Formation. Only the intermediate to felsic rocks $\left(\mathrm{SiO}_{2}\right.$ between about 55 and $76 \%$ ) within the Middletown were analyzed for geochemistry and isotopic ratios; mafic rocks (that is, amphibolites) were not analyzed.

$\mathrm{Nd}$ isotopic data from the five sampled lithologies have a wide range (fig. 11B). Most samples of the Ordovician Boulder Lake and Pond Meadow gneisses have relatively low initial $\varepsilon_{\mathrm{Nd}}$ values between about -5.5 and -1.6 ; the Mississippian Hidden Lake gneiss has similar values of -4.3 to -2.8 (table 4 ). These low initial $\varepsilon_{\mathrm{Nd}}$ values partly overlap data from Neoproterozoic basement rocks of the Gander Zone (about -4 to +2 at $450 \mathrm{Ma}$ ) and partly overlap into the field of Laurentian (Grenville) crust (about -8 to -4 at $450 \mathrm{Ma}$ ). Isotopic data from samples of Ordovician Middletown Formation and Higganum gneiss have much higher initial $\varepsilon_{\mathrm{Nd}}$ values of about +0.9 to +5.2 (table 4 ). These higher values mostly overlap the field of $\mathrm{Nd}$ data from the Avalon Zone (fig. 11B).

Initial $\varepsilon_{\mathrm{Nd}}$ values for Neoproterozoic gneisses of the Clinton and Lyme domes are relatively low ( -2.3 to +0.9 , table 4$)$, plotting within the field of Gander zone data. Neoproterozoic gneiss samples 15W and 15X from the Selden Neck block (fig. 3) have significantly higher initial $\varepsilon_{\mathrm{Nd}}$ values of about 3.9 and 4.6 , respectively, and plot within the field of data for the Avalon Zone (fig. 11B).

DISCUSSION

\section{Geochronology and Geology}

On the basis of whole-rock geochemistry, Webster and Wintsch (1987) subdivided the rocks of the Killingworth dome into four units (fig. 3). This subdivision is supported by our more recent geochemical data set. U-Pb geochronology shows that ages of three units (Pond Meadow, Boulder Lake, and Higganum gneisses) are about 455 to $460 \mathrm{Ma}$, whereas the Hidden Lake gneiss in the core of the dome crystallized 


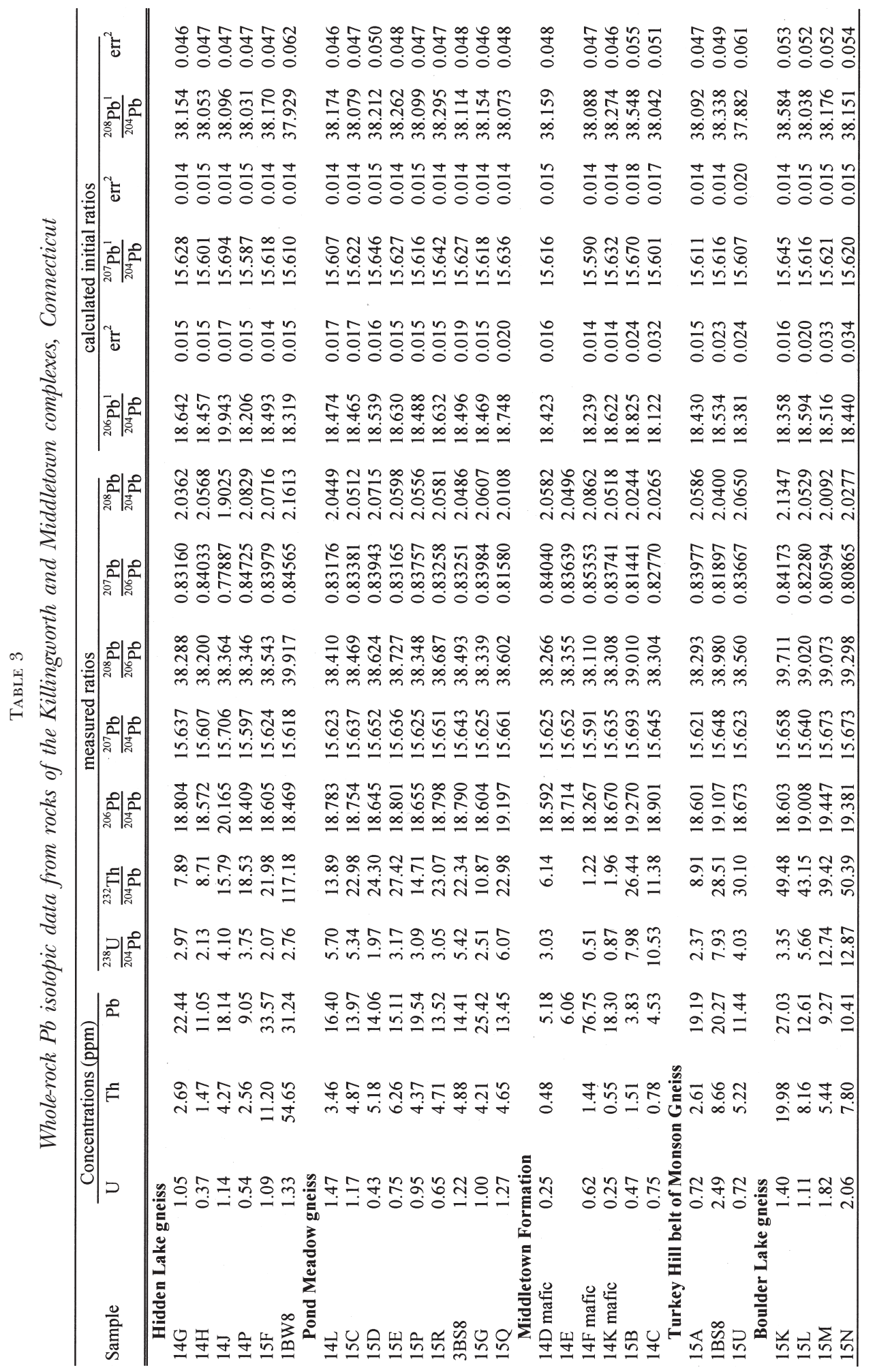




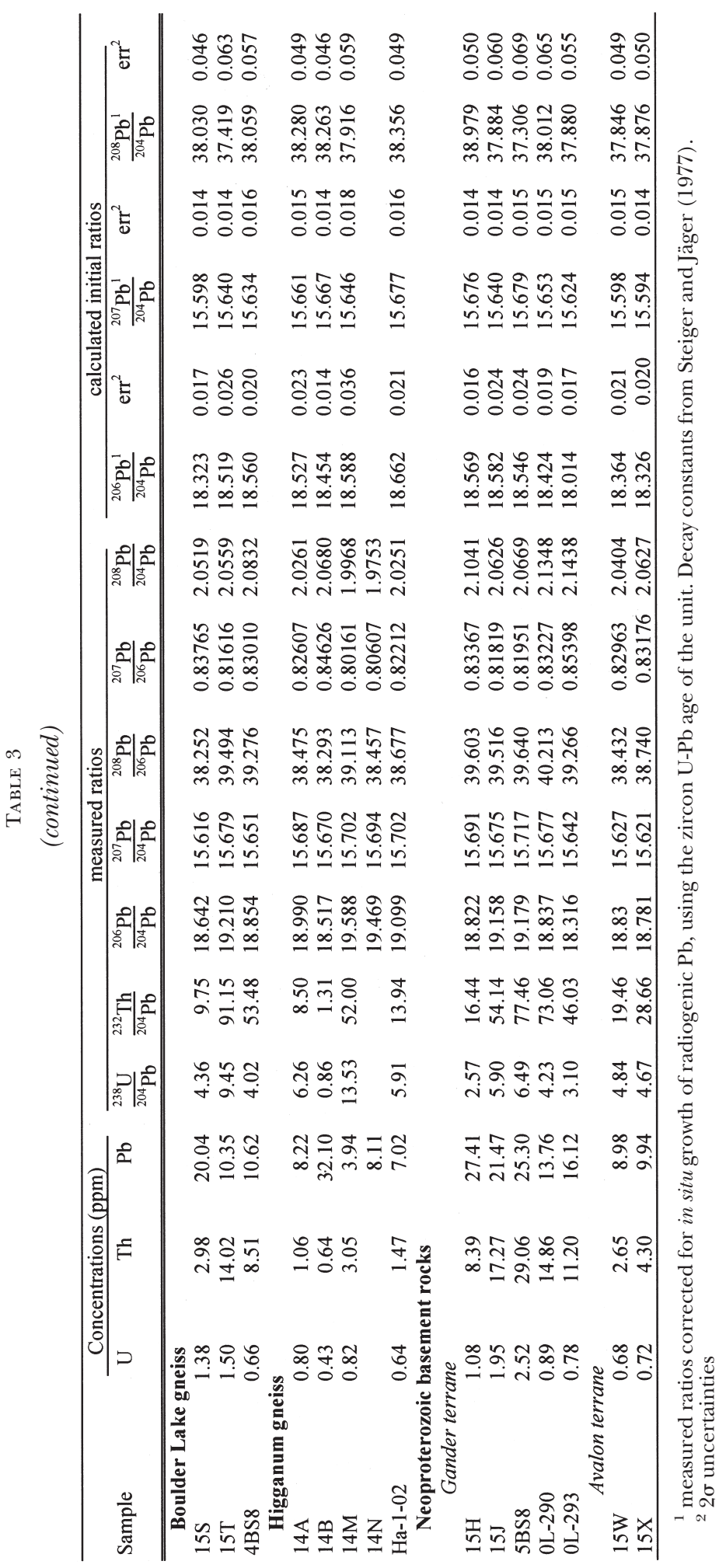




\begin{tabular}{|c|c|c|c|c|c|c|}
\hline & $\mid \sum_{|=|}^{\infty}$ & 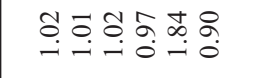 & 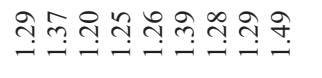 & 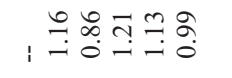 & $\cong \stackrel{0}{\simeq}$ & 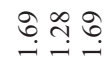 \\
\hline & $\vec{w}$ & 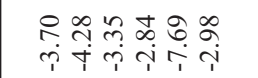 & 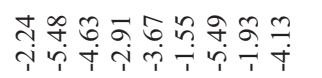 & 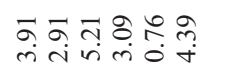 & 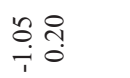 & तु? \\
\hline $\overrightarrow{\mathbb{Z}}$ & $\mid \begin{array}{l}z \\
0 \\
:\end{array}$ & 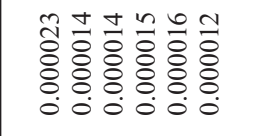 & 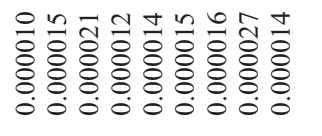 & 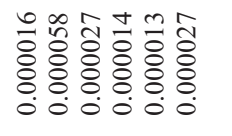 & $\begin{array}{l}\infty \\
\text { ते } \\
0 \\
0 \\
0 \\
0 \\
0 \\
0\end{array}$ & 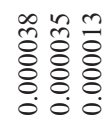 \\
\hline 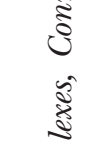 & 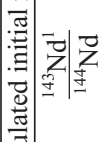 & 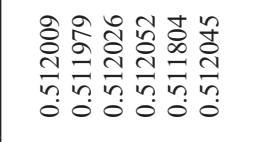 & 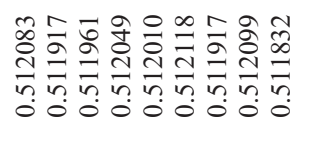 & 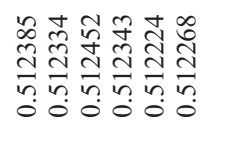 & 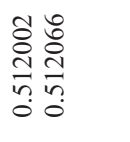 & 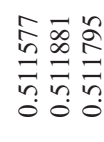 \\
\hline 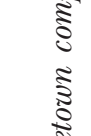 & 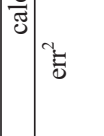 & 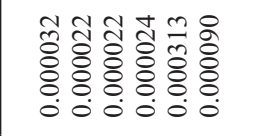 & 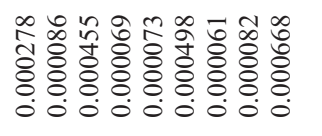 & 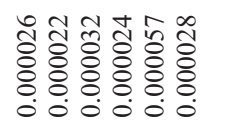 & 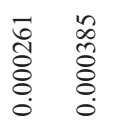 & 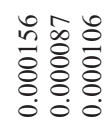 \\
\hline $\begin{array}{l}\mathbb{Z} \\
\mathbb{Z} \\
\mathbb{Z} \\
\mathbb{Z}\end{array}$ & $\left|\begin{array}{l}n \\
i_{\infty}\end{array}\right|$ & 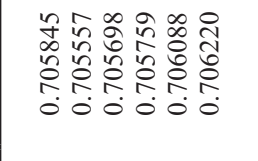 & 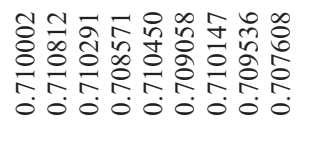 & 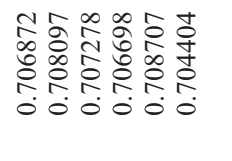 & 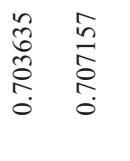 & 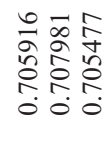 \\
\hline 竎 & $\vec{w}$ & 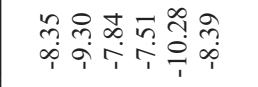 & 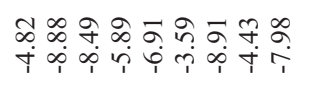 & 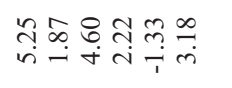 & 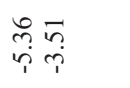 & 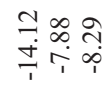 \\
\hline 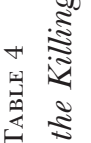 & 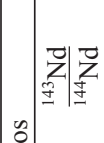 & 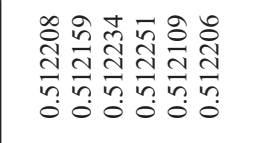 & 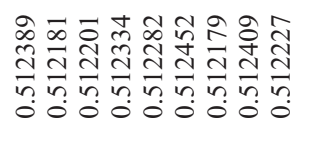 & 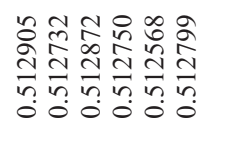 & 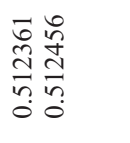 & 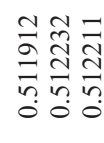 \\
\hline 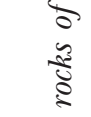 & 离: & 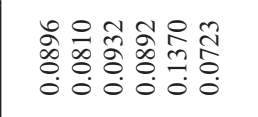 & 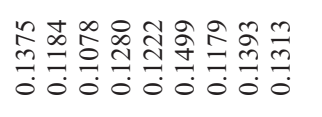 & 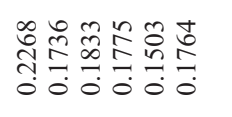 & 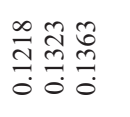 & 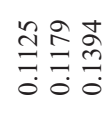 \\
\hline$\frac{8}{8}$ & $\left.\left.\right|_{\infty} ^{\grave{n}}\right|_{\infty} ^{\grave{n}}$ & 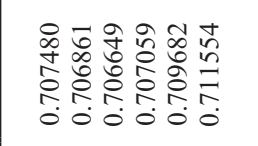 & 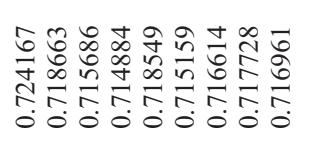 & 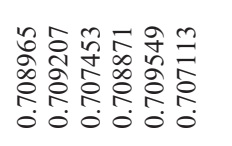 & 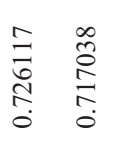 & 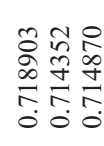 \\
\hline 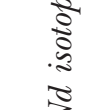 & की & 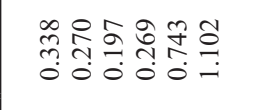 & 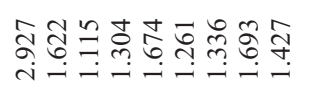 & 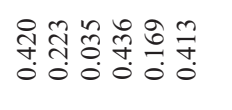 & 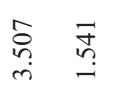 & 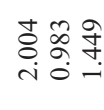 \\
\hline $\begin{array}{l}\text { छ } \\
\text { छ }\end{array}$ & $\vec{z}$ & 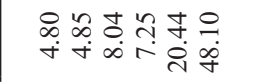 & 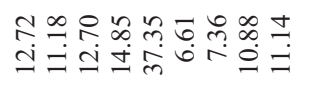 & 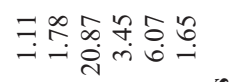 & 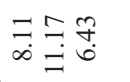 & \\
\hline 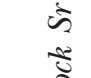 & 형ํำ & 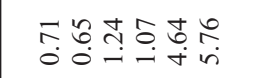 & 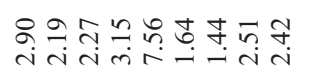 & ఫै. & 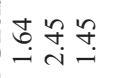 & \\
\hline$\underbrace{\frac{3}{2}}$ & 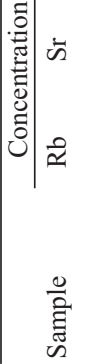 & 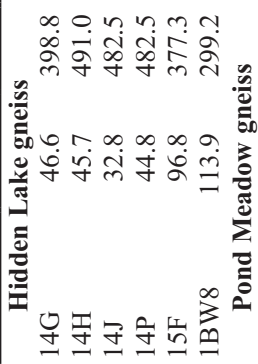 & $\frac{1}{1}$ & 焉 & $\stackrel{n}{n}$ & 2 \\
\hline
\end{tabular}




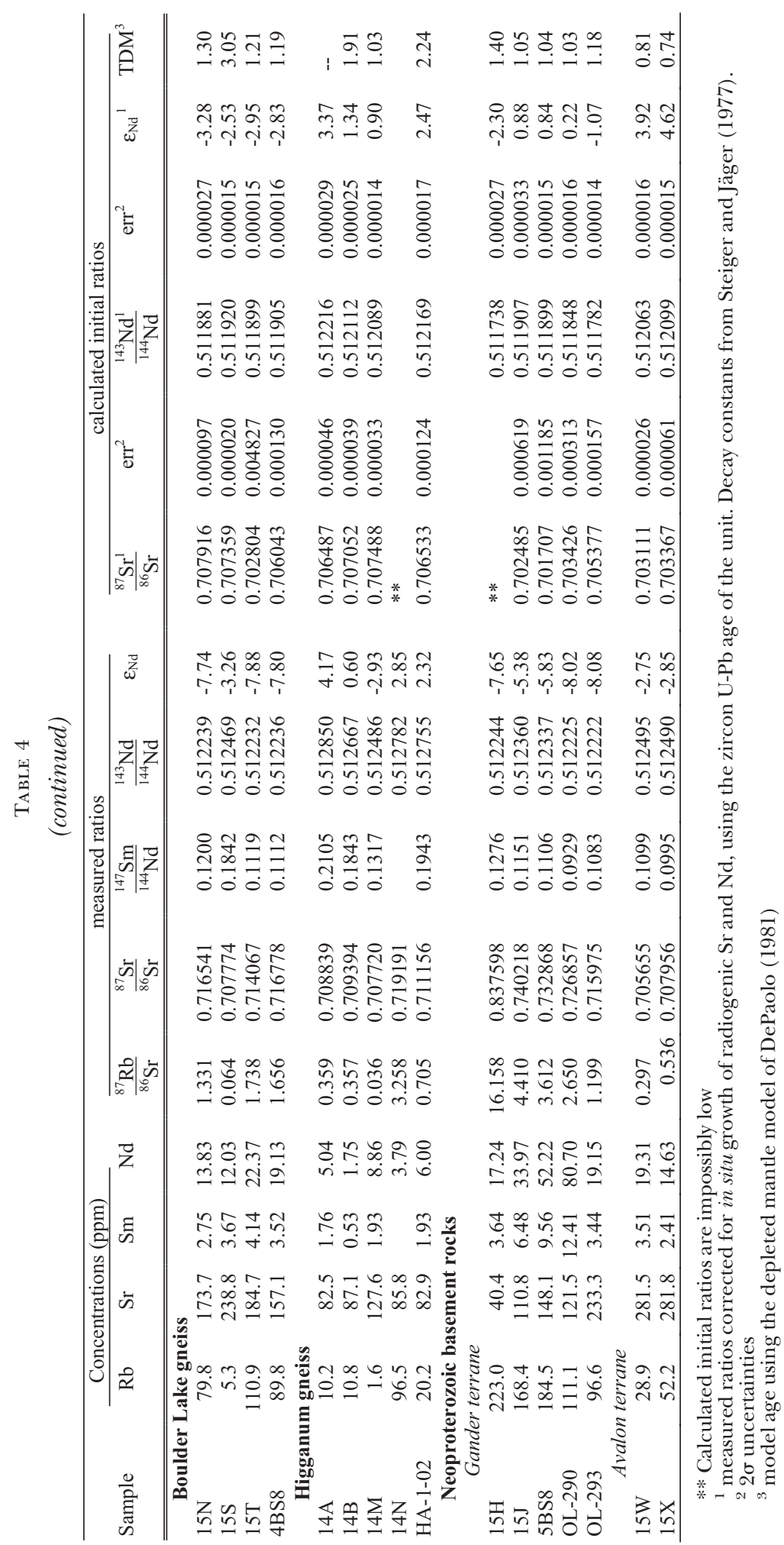



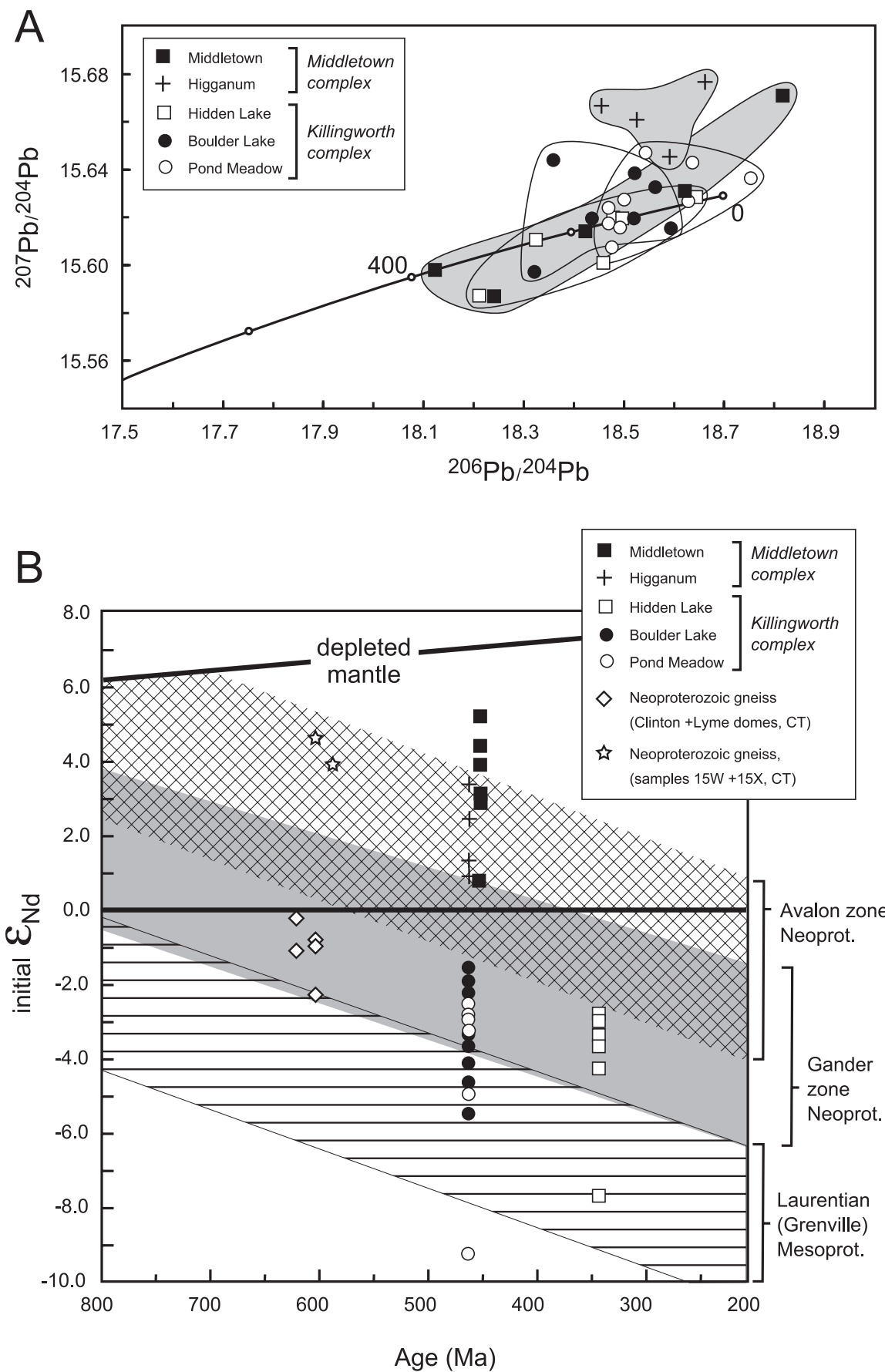

Fig. 11. $\mathrm{Pb}$ and $\mathrm{Nd}$ isotopic data from rocks of the Killingworth dome. (A) Initial $\mathrm{Pb}$ isotopic compositions of whole-rock samples from the Killingworth and Middletown complexes, corrected to the crystallization age of their igneous protoliths. Curve is average crustal Pb evolution of Stacey and Kramers (1975). (B) Initial $\varepsilon_{\mathrm{Nd}}$ versus age for whole-rock samples of the Killingworth and Middletown complexes, and samples of Neoproterozoic basement rocks from southern Connecticut. Fields of Avalon zone and Gander zone from Kerr and others (1995); Laurentian (Grenville) field compiled by Samson and others (2000). Depleted mantle evolution curve from DePaolo (1981). 
about $340 \mathrm{Ma}$. $\mathrm{Nd}$ and $\mathrm{Pb}$ isotopic compositions suggest that the Boulder Lake, Pond Meadow and Hidden Lake magmas (now grouped as the Killingworth complex) were derived from similar crustal sources while the Higganum and Middletown magmas (now grouped as the Middletown complex) were derived from different sources.

The nature of the contact between the Killingworth and Middletown complexes is a matter of controversy. On the east side of the Killingworth dome, Rodgers (1985) shows this contact as a stratigraphic boundary, implying that the Middletown Formation was deposited on plagioclase gneisses of the dome. Mapping by Wintsch (1994) at the southeast end of the belt of Middletown Formation, in the north-central part of the Essex 7.5' quadrangle, suggests a ductile fault between Middletown and rocks now called Pond Meadow and Boulder Lake gneiss. Additional evidence for a fault contact between the Middletown and Killingworth complexes is: (1) the southeast-trending straight boundary between the Middletown and Hidden Lake gneiss in the southeastern Haddam quadrangle (fig. 3), (2) truncation of chemical zoning within the Hidden Lake gneiss by the straight contact (Webster and Wintsch, 1987), and (3) contrast in degree of metamorphic overprint between the pervasively migmatized Pond Meadow gneiss and the strongly foliated and recrystallized Higganum gneiss and Middletown Formation (only recrystallized). Because the Hidden Lake gneiss intruded these rocks at about $340 \mathrm{Ma}$, and shows no evidence of intruding into the Middletown, we consider the contact to be a post-340 Ma fault. Similarly, Lundgren (1979) mapped a thrust fault contact separating a small body of amphibolite (interpreted as Middletown Formation) from the adjacent Pond Meadow gneiss in the north-central part of the Haddam quadrangle. Thus, we conclude that the Killingworth complex and Middletown complex (including the Higganum gneiss) were juxtaposed after $340 \mathrm{Ma}$ (age of zircon overgrowths in the Pond Meadow and new magmatic zircon in the Hidden Lake gneiss). The age of titanite in the Middletown anthophyllite gneiss (about $300 \mathrm{Ma}$ ) may date the time of faulting.

\section{Petrogenesis and Magmatic Sources}

Nearly all rocks of the Killingworth dome exhibit geochemical characteristics indicative of an origin within a magmatic arc or arc-related system. All rocks are magnesian according to the criteria of Frost and others (2001) (fig. 6F), and exhibit calc-alkaline affinity (fig. 12). Nearly all Killingworth rocks are characterized by compositions that are slightly Mg-poor relative to lavas from the mature Cascades arc (Carmichael, 1964). The Hidden Lake gneiss is distinct from other Killingworth gneisses in defining a compositional trend that is nearly coincident with the Cascade rocks. Mafic samples of the Middletown Formation plot separate from associated felsic varieties of the Middletown (fig. 12), defining a possible trend characterized by slight $\mathrm{Mg}$ enrichment relative to the Cascade lavas.

All felsic rocks from the Killingworth dome are characterized by a combination of relatively low $\mathrm{Rb}$ and $\mathrm{Nb}+\mathrm{Y}$ compared to other granitoids worldwide, and thus display compositional similarity to granitoids from volcanic-arc tectonic settings (fig. 13A; Pearce and others, 1984). Island-arc affinity is also indicated by relatively low concentrations of $\mathrm{Ta}$ and $\mathrm{Yb}$ (fig. 13B). However, differences in $\mathrm{Rb}$ concentrations (which are consistent within units, suggesting relative immobililty on the scale of individual samples) in the rocks studied define two groups. Felsic rocks of the Middletown Formation and most of the Higganum gneiss exhibit Rb depletion whereas all other gneisses display relative enrichment. Low Rb concentrations of the Higganum and Middletown rocks correspond to compositions that are characteristic of relatively immature arc suites with minimal involvement of continental crust in magma genesis, such as the Kermadec Islands in the southwest Pacific (Smith and others, 1988) and 


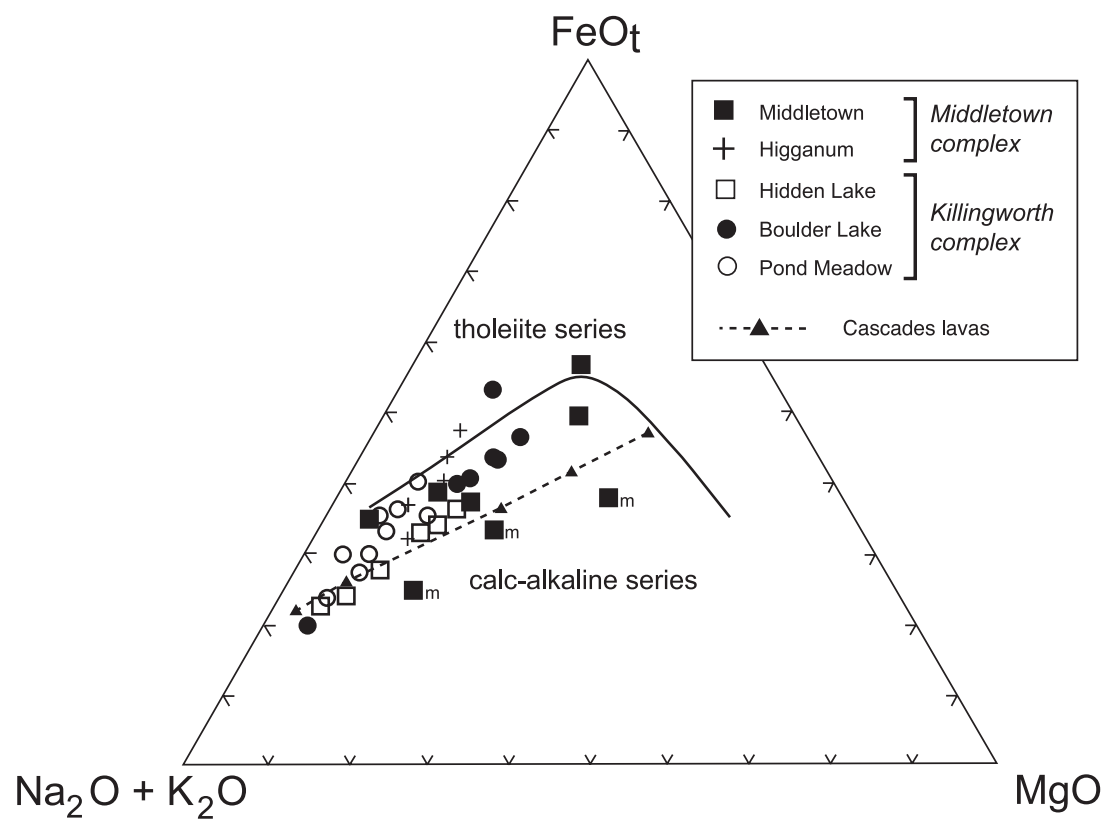

Fig. 12. AFM plot of $\left(\mathrm{Na}_{2} \mathrm{O}+\mathrm{K}_{2} \mathrm{O}\right)$ vs $\mathrm{FeO}_{\mathrm{t}}$ vs $\mathrm{MgO}$ for gneisses of the Killingworth dome. Coordinates are calculated using weight percent of the element oxides. Mafic samples of the Middletown Formation are labelled with " $\mathrm{m}$ ". Solid line separating fields of tholeiitic and calc-alkaline series from Irvine and Baragar (1971). Compositions of Cascade lavas (dashed line) from Carmichael (1964).

mid-Oligocene plutonic rocks of the Cordillera de Talamanca in Costa Rica and Panama (Drummond and others, 1995). In contrast, Förster and others (1997) noted that higher $\mathrm{Rb}$ concentrations at comparable $\mathrm{Y}+\mathrm{Nb}$ values, compositional features exhibited by felsic gneisses of the Killingworth complex (fig. 13A), are characteristic of more mature island arcs or evolving island arc-continental arc systems such as the Late Miocene Talamanca intrusive suite (Drummond and others, 1995) which, like the Killingworth gneisses, also displays modest Ta enrichment (fig. 13B). Four of the six data points for the Hidden Lake gneiss plot at lower $\mathrm{Rb}$ values than the moderately enriched Boulder Lake and Pond Meadow gneisses (fig. 13A) and thus were likely derived from compositionally distinct sources.

Petrologic affinity of the Killingworth rocks to arc systems is supported by moderate decoupling of large-ion lithophile (LIL) and high-field strength (HFS) elemental concentrations (Winter, 2001). Especially noteworthy is enrichment, relative to mid-ocean ridge basalt (MORB), in LIL elements $\mathrm{K}, \mathrm{Rb}$, and $\mathrm{Ba}$ (as well as Th), slight depletion in $\mathrm{Ta}$ and $\mathrm{Nb}$, and MORB-like abundances of HFS elements Ce through $\mathrm{Yb}$, except $\mathrm{Ti}$ and $\mathrm{Y}$ (fig. 13C). Normalized elemental concentrations of samples from the Middletown Formation and Higganum gneiss are lower than values for gneisses of the Killingworth complex, and are closer to MORB values. As a result, we suggest that the observed differences reflect petrologic processes and are not the result of alteration. Overall, the Hidden Lake gneiss is similar to some of the other gneisses but is distinguished compositionally by extreme values that fall at either the high or low end of the Killingworth range (fig. 13C). Arc affinity for the Killingworth complex rocks is further indicated by the similar pattern that is characteristic of the calc-alkaline Miocene intrusives from Talamanca (fig. 13C).

The units of the Killingworth and Middletown complexes also can be distinguished using a combination of $\mathrm{Nd}$ and $\mathrm{Pb}$ isotopic data (fig. 14). This type of plot 

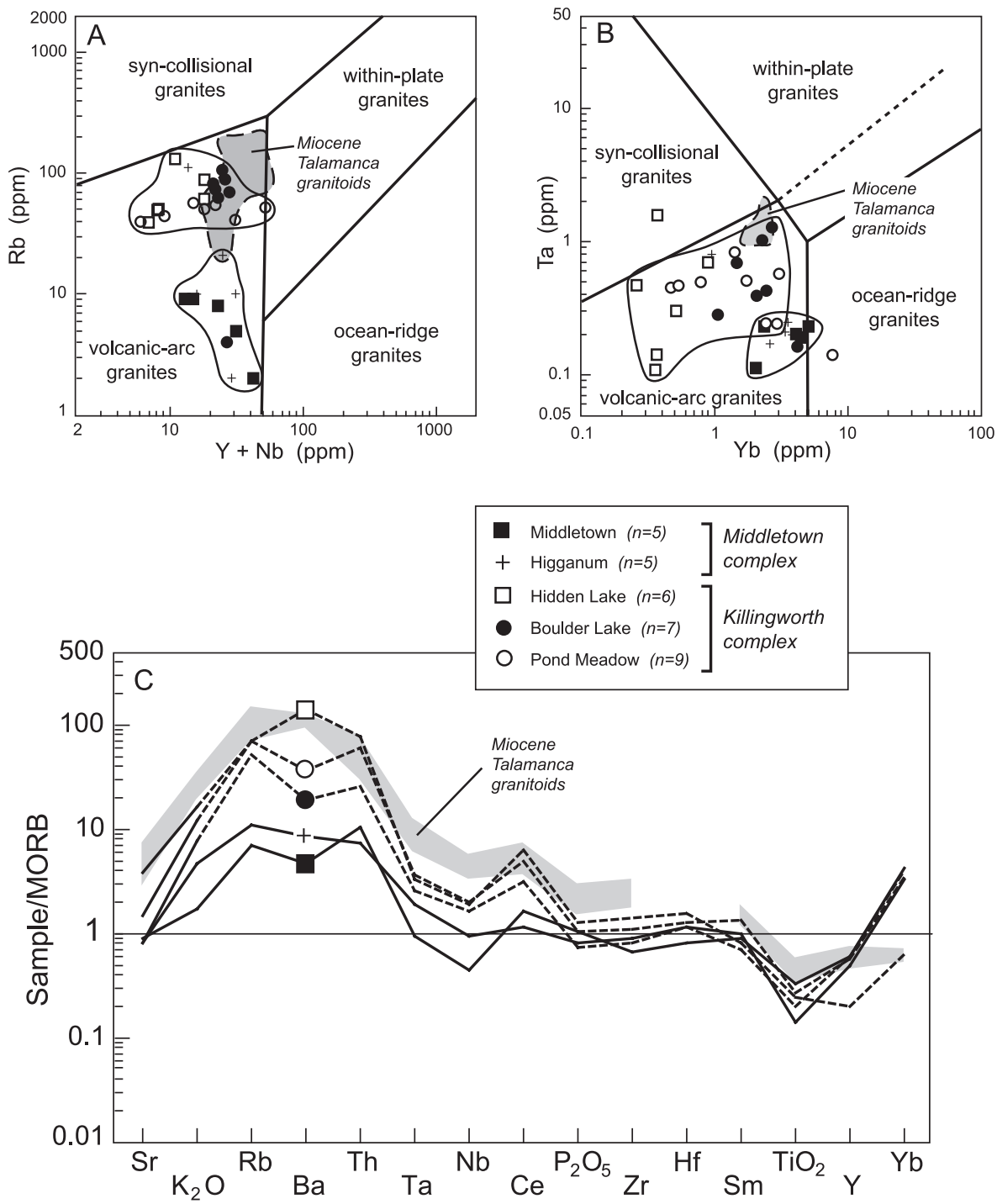

Fig. 13. Geochemical plots of whole-rock data from the Killingworth dome. (A) $(\mathrm{Y}+\mathrm{Nb}) \mathrm{vs} \mathrm{Rb}$. Compositional field of Late Miocene granitoids from the Cordillera de Talamanca of Costa Rica and Panama (29 samples from Drummond and others, 1995) plotted for comparison. Diagram after Pearce and others (1984). (B) Yb vs Ta. Compositional field of Late Miocene granitoids from the Cordillera de Talamanca of Costa Rica and Panama is plotted for comparison (5 samples from Drummond and others, 1995). Diagram after Pearce and others (1984). (C) Plot of average compositions of gneisses from the Killingworth complex and both felsic and mafic rocks of the Middletown Formation normalized to mid-ocean ridge basalt (MORB) using values from Bevins and others (1984) except for Sm which is from Pearce (1983). Compositional field of Late Miocene granitoids from the Cordillera de Talamanca of Costa Rica and Panama is plotted for comparison (5 samples from Drummond and others, 1995).

(initial $\varepsilon_{\mathrm{Nd}}$ versus ${ }^{207} \mathrm{~Pb} /{ }^{204} \mathrm{~Pb}$ ) is valuable because it uses two source-sensitive discriminants (Tomascak and others, 2005). Higganum gneiss and Middletown Formation (including both low and high $\mathrm{SiO}_{2}$ lithologies, table 1) have relatively high initial $\varepsilon_{\mathrm{Nd}}$ (range of about +1 to +6 ), whereas Hidden Lake, Boulder Lake, and Pond Meadow gneisses have lower values of about -9 to -1 . This difference in $\varepsilon_{\mathrm{Nd}}$ supports the $\mathrm{Pb}$ 


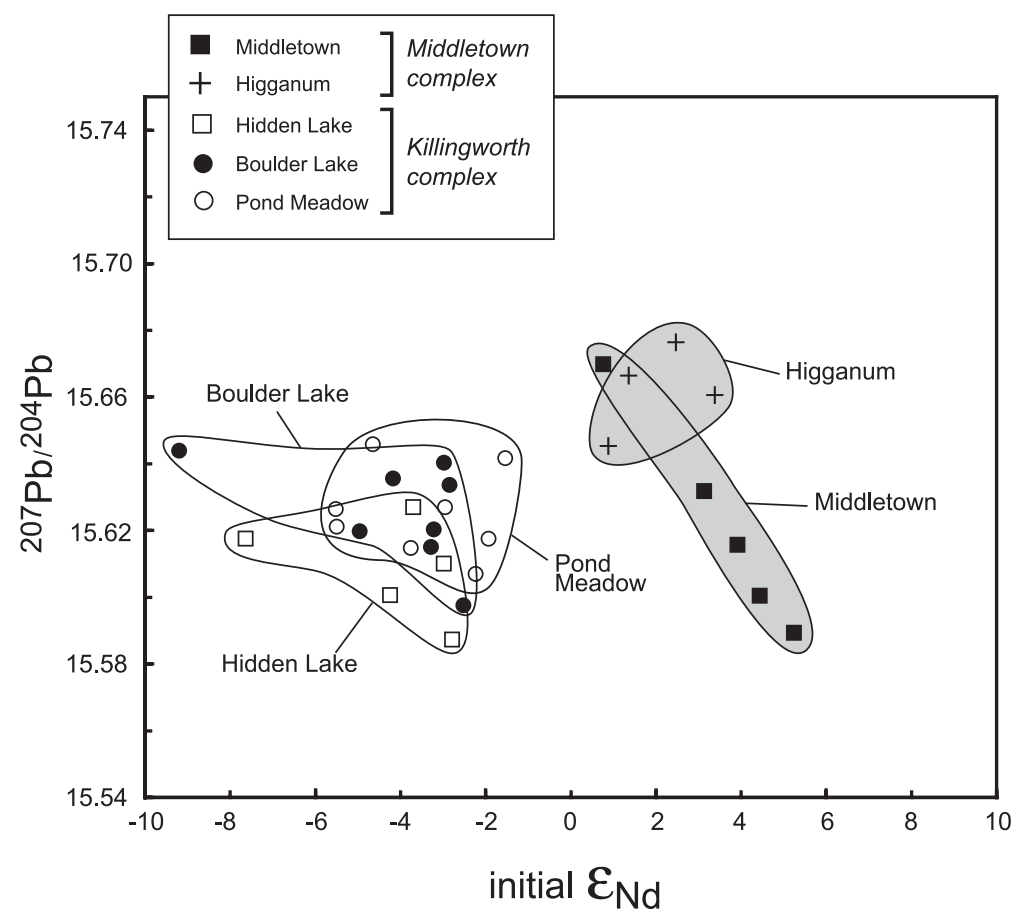

Fig. 14. Initial $\varepsilon_{\mathrm{Nd}}$ versus ${ }^{207} \mathrm{~Pb} /{ }^{204} \mathrm{~Pb}$ of whole-rock samples from the Killingworth and Middletown complexes.

isotopic data and several geochemical discriminants that suggest that the Higganum and Middletown magmas were derived from sources that differed from those of the Killingworth complex. In addition, the higher $\varepsilon_{\mathrm{Nd}}$ values for the Higganum and Middletown imply a more primitive source component, whereas the negative $\varepsilon_{\mathrm{Nd}}$ values for the Hidden Lake, Boulder Lake, and Pond Meadow gneisses indicate an older, more evolved crustal source.

To evaluate potential sources for the units of the Killingworth dome, we compare data from nearby samples of Neoproterozoic basement rocks, including samples of felsic orthogneiss from the Clinton dome in the Essex quadrangle (samples 15H, 15J, 5BS; table 3, fig. 3) and Lyme dome in the Old Lyme quadrangle (OL-290, and OL-293; table 3), and two samples of felsic gneisses interpreted to be of extrusive and intrusive origin, respectively (Wintsch and others, 1990), from the Selden Neck block (samples 15W and 15X; table 3, fig. 3). Pb isotopic data from samples from the Clinton and Lyme domes plot above the average growth curve (Stacey and Kramers, 1975) whereas data from samples from the Selden Neck block are distinctly less radiogenic, plotting below the average growth curve (fig. 15A). Four of five analyses from Clinton and Lyme dome rocks overlap $\mathrm{Pb}$ isotopic data for Gander terrane basement gneisses rocks in New Brunswick (fig. 15A; Ayuso and Bevier, 1991). ${ }^{1}$ Samples 15W and 15X

${ }^{1}$ This zone or belt was called "Southern Group" by Ayuso and Bevier (1991). It was originally interpreted as "Avalonian" in origin, in recognition of its very different isotopic composition compared to Laurentian (or Grenville) rocks to the west. These rocks can be traced northeast to Cape Breton Island, New Brunswick, and Newfoundland. The belt has been given a number of names, including Bras D'Or, Miramichi, Western Avalonia, Eastern Central Mobile Belt, and many local terrane names. Confusion arises when consulting older literature that refers to these rocks as Avalonian in origin. It is now known that in Newfoundland, the 
have similar $\mathrm{Pb}$ isotopic ratios to Silurian-Devonian granitic rocks interpreted as having been derived from Neoproterozoic basement of the Avalon terrane in New Brunswick and Newfoundland. Unfortunately, there is no comparable data set for Neoproterozoic basement rocks of the Avalon terrane. The ${ }^{207} \mathrm{~Pb} /{ }^{204} \mathrm{~Pb}$ ratios of Paleozoic granitoids of Avalon (and samples 15W and 15X) are lower than in Paleozoic granitic rocks in the Gander terrane (Kerr, 1997).

Potential source rocks for the magmas of the Killingworth and Middletown complexes can also be evaluated on the $\varepsilon_{\mathrm{Nd}}$ versus ${ }^{207} \mathrm{~Pb} /{ }^{204} \mathrm{~Pb}$ plot (fig. $15 \mathrm{~B}$ ). Whole-rock data from samples of Gander terrane in southern Connecticut have relatively low $\varepsilon_{\mathrm{Nd}}$ values and relatively high ${ }^{207} \mathrm{~Pb} /{ }^{204} \mathrm{~Pb}$. Data from 4 (of 5) samples overlap the field of Gander basement (data from Ayuso and Bevier, 1991; Kerr and others, 1995), whereas samples 15W and 15X from the Selden Neck block have higher $\varepsilon_{\mathrm{Nd}}$ values and lower ${ }^{207} \mathrm{~Pb} /{ }^{204} \mathrm{~Pb}$ reflecting more primitive sources. These data confirm that gneisses of the Clinton and Lyme domes belong to the basement of the Gander terrane, and that samples 15W and 15X from the Selden Neck block belong to the Avalon terrane. The combined field of data for Boulder Lake, Pond Meadow, and Hidden Lake gneisses plots between fields of data for Gander basement and Laurentian (Grenville) crust and above isotopic data for rocks of the Bronson Hill terrane of northern New Hampshire (Lathrop and others, 1996; Moench and Aleinikoff, 2003). Higganum gneiss and Middletown Formation plot to the right of and slightly below the data field for Gander crust, on a trajectory toward model mantle at $450 \mathrm{Ma}$ (fig. 15B).

We suggest that all units of the Killingworth dome have mixed sources. The two volcanic magmas (Higganum and Middletown of the Middletown complex) are the result of mixing of Gander and primitive (that is, mantle) components. The three plutonic units (Boulder Lake, Pond Meadow, and Hidden Lake of the Killingworth complex) probably were derived from a mixture of Neoproterozoic Gander rocks and a less radiogenic component. Laurentian (Grenvillian) rocks have lower ${ }^{207} \mathrm{~Pb} /{ }^{204} \mathrm{~Pb}$ and $\varepsilon_{\mathrm{Nd}}$ values, and now occur relatively close to the Killingworth dome. However, consideration of paleogeographic location indicates that the Gander terrane originated far from Laurentia, across the Iapetus ocean. We discuss other possible sources below in the context of Paleozoic tectonic reconstructions.

\section{Provenance of Detrital Zircons}

Isotopic evidence suggests that the Killingworth complex was derived from a mixture of Gander basement and less radiogenic material that has isotopic characteristics similar to Laurentian (Grenville) rocks. However, it is now known (on the basis of paleomagnetic data and identification of faunal realms; Harper and others, 1996; Mac Niocaill and others, 1997) that Gander formed as a peri-Gondwanan terrane. Tectonic models (van Staal and others, 2004; Valverde-Vaqureo and others, 2006), suggest that Gander accreted to the Laurentian margin in the Silurian ( $430 \mathrm{Ma})$ during the Salinic orogeny, implying that Gander would not have received Laurentian sediments until late in its accretionary history, well after creation of the Killingworth complex. In southern New England, accretion of Gander to Laurentia may have occurred somewhat earlier, perhaps beginning in the Late Ordovician (but several m.y. after emplacement of the Killingworth complex magmas), on the basis of isotopic compositions of plutonic rocks in western Connecticut (Sevigny and Hanson, 1993, 1995).

Dover fault separates Avalon sensu stricto (to the southeast) and Gander (to the northwest) terranes, both of which contain Neoproterozoic crystalline basement rocks (van Staal and others, 1996). This discontinuity has been traced southwest (compare, Whalen and others, 1996; Pe-Piper and Piper, 1998). Regardless of original name, the term Gander will be used throughout this paper to refer to Neoproterozoic rocks (and derivatives thereof) that have high ${ }^{207} \mathrm{~Pb} /{ }^{204} \mathrm{~Pb}$ and negative initial $\varepsilon_{\mathrm{Nd}}$ values. The term Avalon (Barr and White, 1996; Barr and others, 2002) will be restricted to Neoproterozoic rocks (and derivatives thereof) with low ${ }^{207} \mathrm{~Pb} /{ }^{204} \mathrm{~Pb}$ and positive $\varepsilon_{\mathrm{Nd}}$ values. 

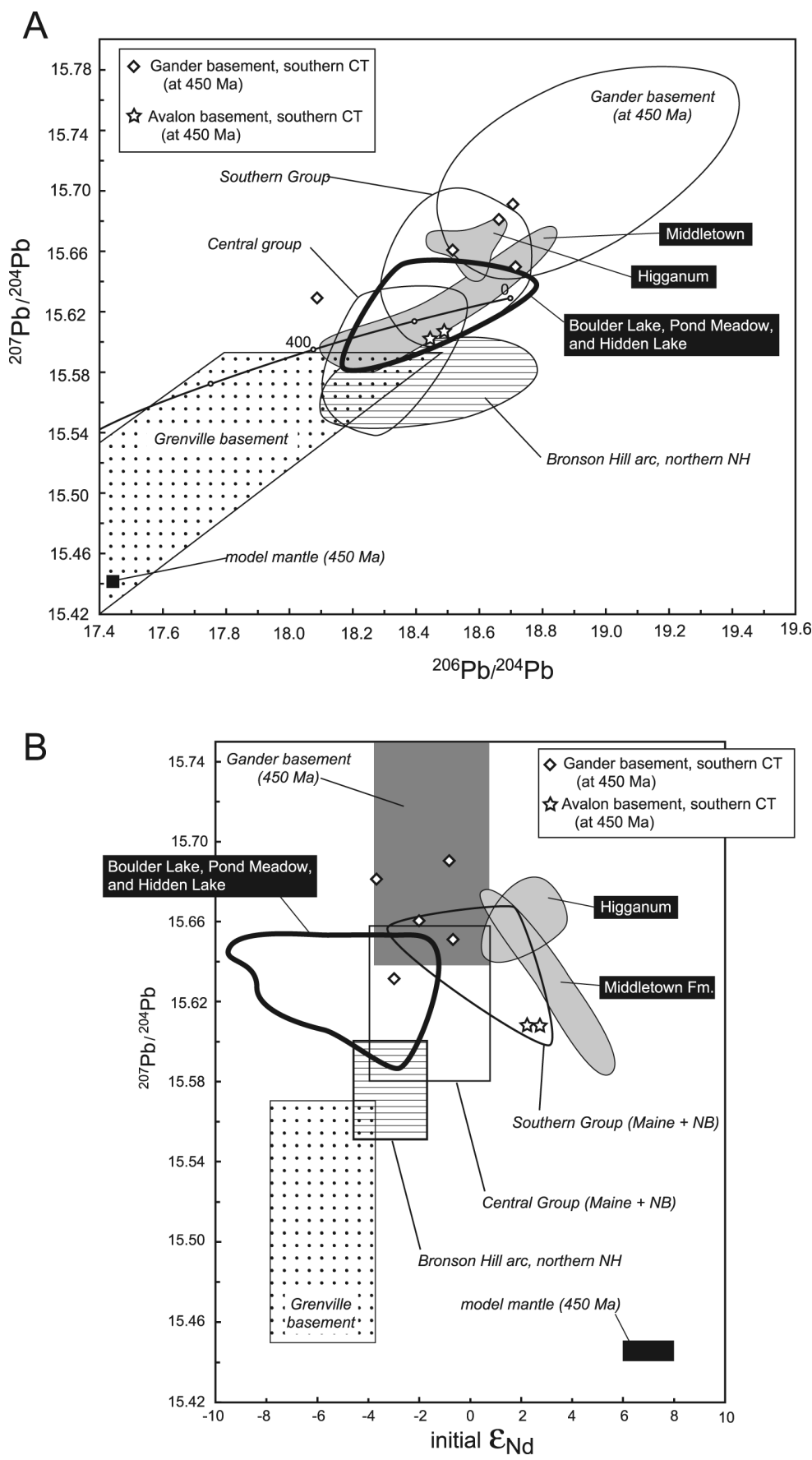

Fig. 15. Pb and $\mathrm{Nd}$ isotopic data from rocks of the Killingworth dome and nearby Neoproterozoic rocks. (A) Fields of initial $\mathrm{Pb}$ isotopic compositions of whole-rock samples of the Killingworth and Middletown complexes, plus $\mathrm{Pb}$ isotopic data (corrected to $450 \mathrm{Ma}$ ) from whole-rock samples of Neoproterozoic basement rocks of southern Connecticut. Also shown are fields of potential sources: Gander basement, corrected to $450 \mathrm{Ma}$, from New Brunswick (Ayuso and Bevier, 1991), Grenville basement (compiled in Ayuso and Bevier, 1991), granitic rocks from the northern portion of the Middle Ordovician Bronson Hill arc, NH (Moench and Aleinikoff, 2003), fields of initial ratios of Paleozoic plutons of Maine and New Brunswick (Central and Southern Groups, Ayuso and Bevier, 1991), and model mantle (Zartman and Haines, 1998). 
Mesoproterozoic material is common in the Gander terrane. For example, quartzite within the Neoproterozoic metasedimentary Old Lyme gneiss of the Lyme dome (Walsh and others, 2007) contains a large population of Mesoproterozoic (about $0.9-2.1 \mathrm{Ga}$ ) detrital zircons. These ages are similar to inheritance ages in igneous zircons from the Neoproterozoic Dry Hill Gneiss, Massachusetts (Tucker and Robinson, 1990), and ages of detrital zircons from Neoproterozoic Westboro Formation of the Boston basin (Thompson and Bowring, 2000) and in our sample of anthophyllite gneiss (figs. 9A and 9B) of the Middletown Formation. Mesoproterozoic ages of detrital zircons have also been found in sedimentary rocks of Avalon and Gander terranes in New Brunswick and Nova Scotia (Barr and others, 2003; Reusch and others, 2004). Possible non-Laurentian, peri-Gondwanan sources for Mesoproterozoic zircons include Amazonia, Oaxaquia, and Baltica (Ortega-Gutierrez and others, 1995; Thompson and Bowring, 2000, and references therein). On the basis of a number of criteria (including detrital zircon age populations, fauna identification, and paleomagnetic data), Nance and Murphy (1996) and van Staal and others (1996) conclude that the most likely provenance for Mesoproterozoic material in Gander terrane rocks is Amazonia. Pb isotopic compositions from Amazonian rocks (Tohver and others, 2004; Loewy and others, 2004, and references therein) are consistent with this interpretation.

\section{Metamorphism}

One intriguing aspect of this study is the apparent lack of evidence for the Devonian Acadian orogeny in rocks of the Killingworth dome. In contrast to rocks of central and northern New England where geochronologic evidence for the Devonian Acadian orogeny is well documented (Eusden and Barreiro, 1988; Spear and Harrison, 1989; Tucker and Robinson, 1990), we find no evidence of Devonian metamorphism in the Killingworth dome. Geochronologic data from zircon and titanite from rocks of this study show that overgrowths on Ordovician magmatic zircons are all younger than Devonian, and formed nearly continuously between about 340 and 270 Ma. Titanite in anthophyllite gneiss of the Middletown Formation formed at about 300 and $250 \mathrm{Ma}$. These data are consistent with other $\mathrm{U}-\mathrm{Pb}$ and argon isotopic results and modeling suggesting that while tectonic loading began in the Late Mississippian, peak metamorphic temperatures were not achieved until the Middle Permian, and were quenched to $<\sim 500^{\circ} \mathrm{C}$ by early Triassic (Wintsch and others, 2003). A similar lack of evidence for Acadian overprinting was noted by Aleinikoff and others (2002) in the Glastonbury gneiss nearby to the north (fig. 2), and in Ordovician plutonic rocks of western Connecticut (Sevigny and Hanson, 1995). In contrast, Wintsch and others (2007) show that Acadian metamorphism is recorded in Gander cover terranes just east of the Killingworth dome in southern Connecticut. For example, the Canterbury and Eastford granitic gneisses were emplaced into metasedimentary rocks of the Merrimack terrane at about $414 \pm 3$ and $379 \pm 4$ Ma, respectively, and metasedimentary rocks of the Tatnic Hill Formation (Putnam-Nashoba terrane) were partially melted at $\sim 400 \mathrm{Ma}$.

A detailed explanation for the lack of evidence for the Acadian remains elusive. The absence of Devonian metamorphic zircon and titanite suggests that the grade of metamorphism at that time was too low to form new mineral overgrowths. This is more

Fig. 15 (continued). (B) Fields of initial $\varepsilon_{\mathrm{Nd}}$ versus ${ }^{207} \mathrm{~Pb} /{ }^{204} \mathrm{~Pb}$ of whole-rock samples from the Killingworth and Middletown complexes, plus isotopic data from whole-rock samples of Neoproterozoic basement rocks of southern Connecticut. Nd data for fields of Central and Southern Groups from R. A. Ayuso (personal communication, 2006), Gander basement from Kerr and others (1995), Bronson Hill granitic rocks from Lathrop and others (1996), model mantle from DePaolo (1981). Pb data from references in figure 14A. 
likely than an alternative explanation that such overgrowths were obliterated by high-grade Alleghanian metamorphism. We consider this latter scenario to be unlikely because metamorphic zircon generally contains lower concentrations of minor and trace elements than magmatic zircon (Hoskin and Schaltegger, 2003). As a result, metamorphic zircon should be even less metamict and thus less soluble or reactive than magmatic zircon during subsequent high-grade events. Nevertheless, it is possible that these rocks escaped high-grade Acadian metamorphism because they were sheltered from Acadian deformation, perhaps sequestered in a tectonic reentrant (for example, Lin and others, 1994). We speculate that the rocks of the Killingworth dome and Glastonbury gneiss were structurally high, and not buried to mid-crustal depths until the early Alleghanian orogeny in the Late Carboniferous.

\section{Nature of the Boulder Lake gneiss-Clinton Granite Gneiss Contact}

The contact of the Ordovician Boulder Lake gneiss and Neoproterozoic Clinton Granite Gneiss is a ductile fault (Wintsch and others, 2005) (fig. 3). Because the rocks of the Killingworth and Clinton domes were previously considered to belong to the Bronson Hill and Avalon terranes, respectively, this contact was interpreted as a terrane boundary. However, isotopic data presented herein result in a new interpretation suggesting that rocks of the Killingworth complex and Clinton dome both are parts of the Gander terrane. Thus, this fault separates two igneous complexes of Neoproterozoic and Late Ordovician ages. Anatectic foliation in the Boulder Lake gneiss probably formed at $312 \pm 4 \mathrm{Ma}$ (age of overgrowths, fig. 8D). These high grade metamorphic conditions may have persisted into the Early Permian on the basis of ages of overgrowths (as young as about $300 \mathrm{Ma}$ ) from related rocks of the Killingworth complex (table 1). Because high grade $\left(>\sim 600^{\circ} \mathrm{C}\right.$.) foliation associated with the fault cross-cuts the anatectic foliation in the Boulder Lake gneiss (Wintsch and others, 2005), the time of juxtaposition of the Clinton Granite Gneiss and the Boulder Lake gneiss is therefore constrained to be younger than $\sim 300 \mathrm{Ma}$. A minimum age of faulting is provided by cooling ages of $\sim 260 \mathrm{Ma}$ in amphiboles from the Boulder Lake gneiss (Wintsch and others, 2003), at which time the rocks were being uplifted and had cooled to $\sim 500^{\circ} \mathrm{C}$.

\section{Tectonic Speculations}

Regional correlations. - Ayuso and Bevier (1991) used Pb isotopic compositions of Paleozoic felsic plutons to identify three lower crustal provinces in the northern Appalachians. Their 'northern', 'southern,' and 'central' groups we now recognize to relate to Laurentian, Ganderian, and Mesoproterozoic+Ganderian mixtures, respectively. The $\mathrm{Pb}$ isotopic compositions and $\varepsilon_{\mathrm{Nd}}$ values of the Killingworth complex are similar to isotopic ratios in plutonic rocks of their "Central Group" (figs. 15A and 15B). Isotopic evidence suggests that these rocks are mixtures from Neoproterozoic Gander sources and a less radiogenic component, now thought to be from Mesoproterozoic detritus of peri-Gondwanan origin. Rocks of similar isotopic characteristics extend far to the northeast into New Brunswick (Whalen and others, 1996, 1998; Samson and others, 2000), Nova Scotia (Pe-Piper and Piper, 1998), Cape Breton Island (Barr and Hegner, 1992), and Newfoundland (Kerr and others, 1995; Whalen and others, 1997). All of these magmas are considered to have been derived from peri-Gondwanan (that is, non-Laurentian) crust (compare, O’Brien and others, 1996; Barr and White, 1996), containing Neoproterozoic basement and Paleozoic sedimentary cover and intrusive rocks.

Tonalitic gneisses of similar Ordovician age as rocks of the Killingworth and Middletown complexes occur to the north in central Massachusetts (Tucker and Robinson, 1990). Like the Killingworth rocks, their low $\varepsilon_{\mathrm{Nd}}$ values (Four Mile gneiss, Bull and Robinson, 1994) lead us to conclude that these Massachusetts magmas were 
derived from Ganderian crust. Rocks of the Middletown complex are distinct from the Killingworth complex in their geochemical and isotopic signatures. However, data from R. A. Ayuso (personal communication, 2006) indicate a strong similarity between the Middletown complex and rocks of the "Southern group" of Ayuso and Bevier (1991; figs. 15A and 15B). The isotopic data suggest that the source of these Middletown rocks is a mixture of Gander basement (relatively low initial $\varepsilon_{\mathrm{Nd}}$ and relatively high ${ }^{207} \mathrm{~Pb} /{ }^{204} \mathrm{~Pb}$ ) plus a primitive (mantle) component (high initial $\varepsilon_{\mathrm{Nd}}$ and low ${ }^{207} \mathrm{~Pb} /{ }^{204} \mathrm{~Pb}$ ). A model of multiple sources is consistent with interpretations of the origins of Paleozoic granitic rocks of the Gander zone in New Brunswick and Newfoundland, considered to be derived from Neoproterozoic basement and various amounts of mantle and metasedimentary (crustal?) components (Whalen and others, 1996, 1997; Kerr, 1997).

Rocks of the Killingworth dome have previously been included within the Bronson Hill terrane (Williams, 1978; Hibbard and others, 2006), primarily due to similarities in age and structure with Oliverian domes, and apparent continuity of the belt throughout New England. Interpretations of the tectonic origin of the Bronson Hill terrane, however, remain contentious, including differing opinions about subduction zone polarity and paleogeographic location during arc formation. The arc rocks have been subdivided into two age groups: $\sim 470$ to $485 \mathrm{Ma}$ (Shelburne Falls arc), and $\sim 440$ to $455 \mathrm{Ma}$ (Bronson Hill arc) (Karabinos and others, 1998) with differing tectonic origins. Rocks of the Killingworth dome belong to the younger age group, similar to tonalitic rocks on strike to the north in Massachusetts (Tucker and Robinson, 1990). In the most recent regional compilation, Hibbard and others (2006), in agreement with many earlier studies (Osberg, 1978; Lyons and others, 1982; Tucker and Robinson, 1990) conclude that the Bronson Hill terrane (from Connecticut to at least northernNew Hampshire, and possibly as far northeast as New Brunswick and Newfoundland) formed as a peri-Gondwanan arc system built on Gander basement. In all these tectonic models, rocks of the Killingworth dome (including both the Killingworth and Middletown complexes) are considered part of the Bronson Hill arc, regardless of the crust (Laurentia, Gander, Avalon, or intervening Iapetan oceanic crust) upon which the arc formed.

Redefining of the Bronson Hill terrane.-An evaluation of our isotopic data and previously published data call into question the grouping of all "Bronson Hill" rocks into a single lithotectonic terrane. Middle to Late Ordovician and Devonian plutons of the Bronson Hill terrane in northern New Hampshire (fig. 16) have Pb isotopic compositions (Moench and Aleinikoff, 2003; Tomascak and others, 2005) that plot below the average growth curve (Stacey and Kramers, 1975), similar to Laurentian (Grenville) basement rocks (fig. 15A). We conclude that these magmas were derived from Laurentian crust. Lead isotope compositions of para-autochthonous midOrdovician intrusive rocks in western Connecticut, just east of Cameron's Line (for example, Brookfield and Beardsley plutons; Sevigny and Hanson, 1993, 1995), suggest that they are also of Laurentian origin. We consider them to be the southern extension of the Laurentia-derived Bronson Hill magmatic arc identified in northern New Hampshire (fig. 16).

In contrast, isotopic ratios of rocks of the Killingworth complex are more radiogenic than those derived from Laurentia. Thus, along the "Bronson Hill terrane" between northern New Hampshire and southern Connecticut there appears to be a fundamental boundary separating Laurentian and Ganderian lower crustal blocks. This boundary, called the Red Indian line in Newfoundland, was originally delineated on the basis of contrasting faunal assemblages (Williams and others, 1988). It has been traced west-southwest through mainland Canada (van Staal, 1994) and into Maine (van Staal and others, 1998; Dorais and Paige, 2000). In New Hampshire, Moench and 


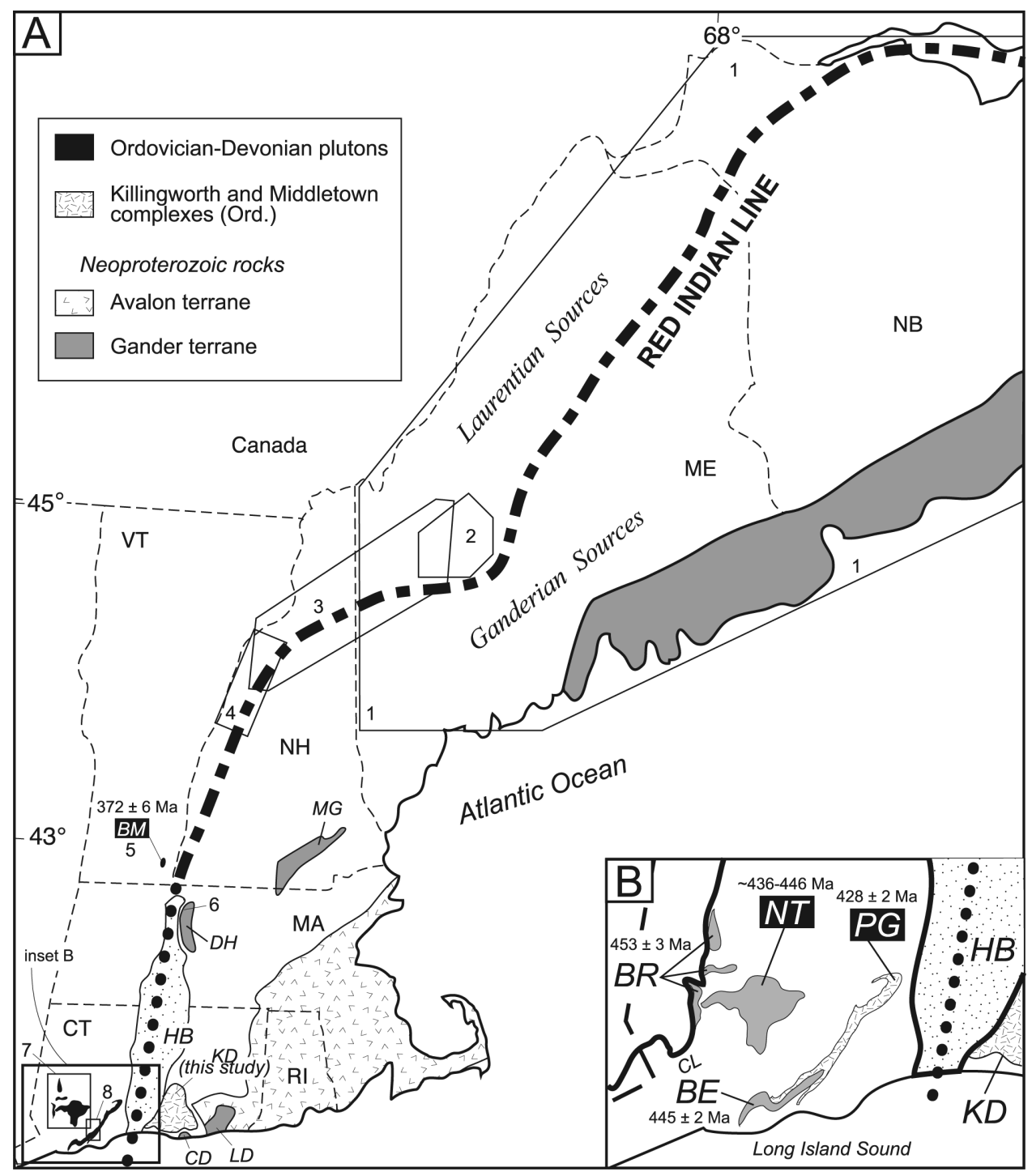

Fig. 16. New interpretation of the location of the Ordovician Iapetan suture (Red Indian line (RIL), Williams and others, 1988) between rocks of Laurentian and Ganderian affinity in southern New England. (A) Simplified map of New England and part of New Brunswick showing distribution of Gander and Avalon terranes (modified from Hibbard and others, 2006). RIL in Maine is modified from Moench and Aleinikoff (2003) to accommodate isotopic data from Tomascak and others (2005). RIL is dotted where speculative in southern New England. In this model, the Laurentia-derived Bronson Hill terrane of northern and western New Hampshire is interpreted to occur in western Connecticut. Rocks of the Killingworth dome (Killingworth and Middletown complexes) are interpreted here to be of Ganderian origin. White-lettered labels with black background in $\mathrm{A}$ and $\mathrm{B}$ are plutons with $\mathrm{Pb}$ isotopic values indicative of Ganderian source components that occur west of the RIL (see text for additional explanation). Abbreviations: BM (Black Mountain pluton), CD (Clinton dome), DH (Dry Hill Gneiss of the Pelham dome), HB (Hartford basin), KD (Killingworth dome), LD (Lyme dome), MG (Massabesic Gneiss). Polygons show locations of previous studies: 1-Ayuso and Bevier (1991), 2-Tomascak and others (2005), 3-Moench and Aleinikoff (2003), 4-Lathrop and others (1996), 5-J. N. Aleinikoff (unpublished data, 1990), 6-Bull and Robinson (1994), 7-Sevigny and Hanson (1995), 8-Sevigny and Hanson (1993). (B) Inset showing plutons of western Connecticut dated and analyzed for initial $\mathrm{Pb}$ isotopic compositions by Sevigny and Hanson (1993, 1995). Abbreviations: CL (Cameron's Line), BE (Beardsley orthogneiss), BR (plutons of the Brookville Plutonic Series), NT (Newtown gneiss), PG (Pumpkin Ground orthogneiss). 


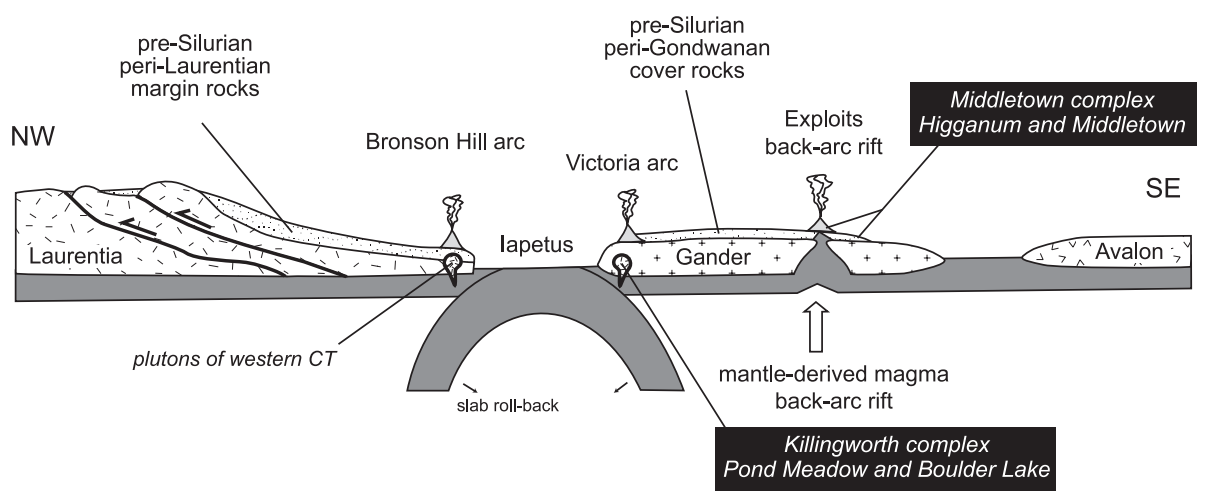

B Mississippian ( 340 Ma)

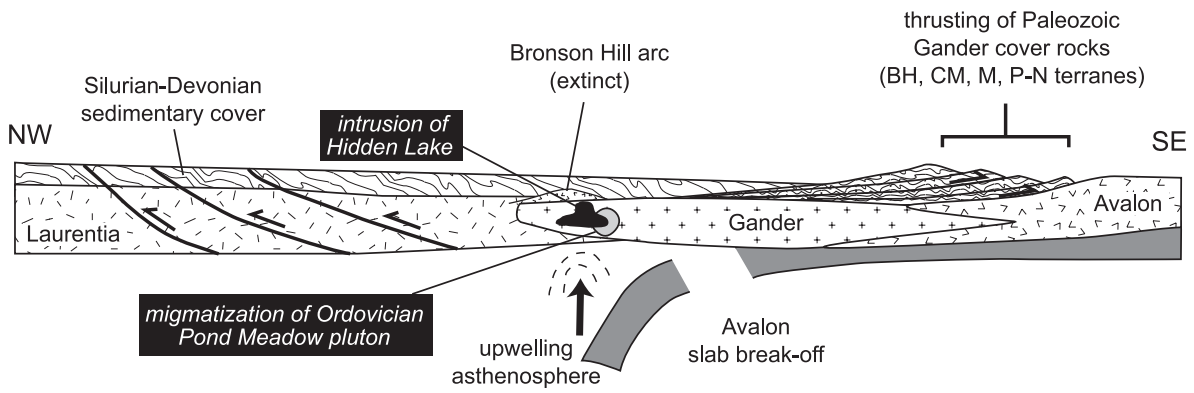

Fig. 17. Schematic cross-sections showing the tectonic evolution of the Killingworth and Middletown complexes. (A) Middle to Late Ordovician. This model assumes the interpretation that Gander accreted to Laurentia in the Silurian (Valverde-Vaquero and others, 2006). (B) Middle Carboniferous. Terrane abbreviations: BH (Bronson Hill), CM (Central Maine), M (Merrimack), P-N (Putnam-Nashoba).

Aleinikoff (2003) present two possible trajectories of the Red Indian line extending southwest into northern Massachusetts, to the east and west of the Neoproterozoic Dry Hill Gneiss of the Pelham dome. Our new interpretation suggests that the Red Indian line traces to the west, on a trend toward western Connecticut.

We conclude that the Ordovician Laurentia-Gander boundary (the Red Indian line) lies approximately under the Hartford basin between the Beardsley gneiss to the west, and Killingworth complex rocks to the east (fig. 16). If this interpretation is correct, then the southern portion of the "Bronson Hill terrane" of figure 1 requires reassignment; it would be correlative with other Ganderian margin arcs, such as the Victoria arc of Newfoundland (Valverde-Vaquero and others, 2006). In the post-Middle Ordovician, Gander wedged farther westward into Laurentia, as shown by the increasing ${ }^{207} \mathrm{~Pb} /{ }^{204} \mathrm{~Pb}$ ratios (that is, increasing Gander component) of Late Ordovician to Devonian plutons (Newtown and Pumpkin Ground gneisses of western Connecticut, Sevigny and Hanson, 1993, 1995; Black Mountain pluton of southeastern Vermont, J. N. Aleinikoff, unpublished data) located west of the Red Indian line (fig. 16).

Ordovician tectonic settings of the Killingworth and Middletown complexes.-We conclude that the Killingworth complex was formed in a magmatic arc environment on, or adjacent to, the western margin of the Gander terrane above an east-dipping subduction zone on the east side of Iapetus (fig. 17A). Contemporaneously, intermediate to 
felsic, and mafic magmas of the Middletown complex were generated in a different tectonic setting according to trace-element and isotopic data. ${ }^{207} \mathrm{~Pb} /{ }^{204} \mathrm{~Pb}$ and $\varepsilon_{\mathrm{Nd}}$ isotopic values suggest that the Middletown complex is the result of mixing of Gander basement with a less radiogenic, more primitive component such as oceanic crust or mantle, without a significant older crustal component (fig. 15B). These data are consistent with an origin for the Middletown complex in a back-arc setting (fig. 17A). There is insufficient evidence at present to determine modes of origin, such as fractional derivation from more primitive magmas or partial melting of earlier underplated mantle-derived material, for these largely felsic rocks.

The proposed tectonic setting for the Killingworth and Middletown complexes is nearly identical to the model of Valverde-Vaquero and others (2006) for rocks of the Victoria arc and Exploits subzone within the Gander zone of Newfoundland. Correlative units have been traced to the British Isles and maritime Canada (Valverde-Vaquero and others, 2006, and references therein). We suggest that these zones can now be extended to southern New England. At about the same time (in the Middle to Late Ordovician), arc rocks of the Bronson Hill terrane were being formed above a west-dipping subduction zone on or adjacent to Laurentia (Sevigny and Hanson, 1995; Karabinos and others, 1998; Kim and Jacobi, 2002)

Late Paleozoic tectonic setting.-In the Mississippian, the Hidden Lake pluton was emplaced and the Pond Meadow gneiss was partially melted. We speculate that this magmatic event was brought about by renewed collision of the Avalon terrane (fig. 17B) during the assembly of Pangea. This shortening event may have led to delamination and subsequent slab break-off of Avalonian lithospheric mantle under the Gander terrane farther to the west, resulting in asthenospheric upwelling that heated the lower crust, and caused remelting of the Killingsworth complex. Initially, this heat melted the root of the former arc, producing the Hidden Lake pluton. Continued heating led to partial melting of Ordovician arc rocks, as exemplified by local migmatization in the Pond Meadow gneiss. In addition, ${ }^{40} \mathrm{Ar} /{ }^{39} \mathrm{Ar}$ cooling ages of $\sim 340$ Ma from amphiboles of the Putnam-Nashoba terrane record the early stages of exhumation of these rocks over the Avalon terrane in the east (Wintsch and others, 1992, 1993). The Mississippian event at about $340 \mathrm{Ma}$ is somewhat cryptic because it is $\sim 40$ m.y. earlier than final assembly of Avalon with amalgamated Laurentia+Gander in the Pennsylvanian (Wintsch and others, 2003, 2005; Walsh and others, 2007). This latter event is the beginning of the Alleghanian orogeny in this area and is recorded by titanite $(\sim 300 \mathrm{Ma})$ from the Middletown complex (fig. 9E); it may also represent the time of thrust emplacement of the Middletown over the Killingworth complex, which must have occurred after migmatization of the Pond Meadow gneiss and emplacement of the Hidden Lake gneiss ( $>340 \mathrm{Ma})$.

\section{CONCLUSIONS}

The Killingworth dome of southern Connecticut exposes Middle to Late Ordovician (about 455-460 Ma) and Mississippian (about $340 \mathrm{Ma}$ ) tonalitic to trondhjemitic orthogneisses, here named the "Killingworth complex." These rocks are flanked by the Middle to Late Ordovician (about 450 - $460 \mathrm{Ma}$ ) "Middletown complex", which includes the Higganum gneiss (formerly considered part of the Killingworth complex) and Middletown and Collins Hill Formations.

Geochemical and isotopic data suggest that rocks of the Killingworth complex originated in a volcanic-arc tectonic setting and were derived primarily from Gander terrane sources that likely included Neoproterozoic basement of Gander and older crustal material. Published paleomagnetic and paleontologic data indicate that this Mesoproterozoic material could not have been derived from Laurentia, but was originally derived from a peri-Gondwanan terrane such as Amazonia. Rocks of the Middletown complex were likely derived from a mixture of Gander basement and a more primitive source, probably in a back-arc setting. Although on strike with similar 
rocks of the Bronson Hill terrane in northern New England, the Killingworth and Middletown complexes appear to have originated on or adjacent to Gander terrane. Rocks of the Bronson Hill terrane occur in western Connecticut.

Final juxtaposition of the Killingworth and Middletown complexes occurred after Mississippian migmatization of the Pond Meadow gneiss and crystallization of the Hidden Lake gneiss, during the Alleghanian orogeny in the late Pennsylvanian or early Permian. We have found no evidence for the Acadian orogeny in the Killingworth or Middletown complexes, suggesting that these rocks remained relatively shallow, or remote from the Laurentian margin, until the Alleghanian.

\section{ACKNOWLEDGMENTS}

This work was initiated and funded by Tom Armstrong and Bill Burton of the USGS Bedrock Regional Aquifer Systematics Study (BRASS) project and by NSF grant EAR-0510293 to R. Wintsch and M. Dorais. We thank Joe Taggert, Jim Budahn, and Brian Marshall for rock analyses, Ezra Yacob for mineral separations, and Joe Wooden and Frank Mazdab for help with SHRIMP analyses. Conversations with Robert Ayuso and Bob Scott proved illuminating. We are grateful to Janet and Byron Stone for logistical support and hospitality in the field. Conversations with John Rodgers, Larry Lundgren, and Dick Goldsmith inspired our early interest and work in this area. We greatly appreciate thoughtful technical reviews by Robert Ayuso, Paul Karabinos, Michel Malo, and Greg Walsh.

APPENDix

ANALYTICAL METHODS

Whole-rock Analyses

Major- and trace-element concentrations were determined by X-ray fluorescence (XRF) and instrumental neutron activation analysis of whole-rock powders in the analytical facilities of the U.S. Geological Survey (USGS), Denver. Elemental oxide abundances of $\mathrm{SiO}_{2}, \mathrm{TiO}_{2}, \mathrm{Al}_{2} \mathrm{O}_{3}$, total $\mathrm{Fe}$ as $\mathrm{Fe}_{2} \mathrm{O}_{3}, \mathrm{MgO}, \mathrm{CaO}, \mathrm{Na}_{2} \mathrm{O}$, $\mathrm{K}_{2} \mathrm{O}, \mathrm{P}_{2} \mathrm{O}_{5}$ and $\mathrm{MnO}$ were determined by wavelength-dispersive x-ray fluorescence (WD-XRF). To obtain loss on ignition (LOI), a $0.8 \mathrm{~g}$ portion of each sample was ignited at $925^{\circ} \mathrm{C}$ for 45 minutes and re-weighed to measure loss. Each sample was then fused with lithium borate flux to create a homogeneous pellet for analysis.

The precision of the major- and minor-elemental determinations is typically less than or equal to 1.0 relative percent, based on replicate analysis of prepared standards, whereas accuracy is less than or equal to 2 percent. A full description of the WD-XRF technique is given in Taggart and Siems (2002). X-ray fluorescence analysis of $\mathrm{Rb}, \mathrm{Sr}, \mathrm{Y}, \mathrm{Zr}, \mathrm{Nb}, \mathrm{Ba}$, Ce, and La was performed using an energy-dispersive detector. These concentrations are precise to \pm 10 percent. Accuracy of all geochemical data was assured by calibration to a suite of internationally accepted standards.

Abundances of thirty-three major, minor, and trace elements, including 11 rare-earth elements (REE), were determined by instrumental neutron activation analysis (INAA). Samples of about one gram were irradiated in the USGS-TRIGA reactor at a flux of $2.5 \times 10^{12}$ for eight hours. Three sequential counts at 7 days, 14 days, and 65 days after the irradiation were made on both coaxial and planar germanium detectors. A summary of the INAA procedure used at the USGS is given in Budahn and Wandless (2002). Precision and accuracy for most of the elements determined range from 1 to 5 percent, including La, Yb, Hf, Ta, Rb, Th, and $\mathrm{U}$. Only five elements have precision errors of greater than 10 percent $(\mathrm{Ho}, \mathrm{Tm}, \mathrm{W}, \mathrm{Sb}$, and $\mathrm{Au})$ based on counting statistic errors. Accuracy is based on replicate analysis of USGS standard reference materials, including BHVO-1.

SHRIMP U-Pb Geochronology of Zircon and Ttitanite

U-Pb geochronology of zircon was performed using the U.S. Geological Survey/Stanford University sensitive high resolution ion microprobe-reverse geometry (SHRIMP-RG). Titanite from one sample was dated using the SHRIMP II at the Research School of Earth Sciences, Australian National University. About $10 \mathrm{~kg}$ of rock were collected for each sample dated. Zircon (and titanite, where present) was extracted using standard mineral separations techniques, including crushing, pulverizing, Wilfley table, magnetic separator, 
and heavy liquids. Individual grains were hand picked, mounted in epoxy, ground to half-thickness to expose internal zones, and polished using $6 \mu \mathrm{m}$ and $1 \mu \mathrm{m}$ diamond suspension. All grains were imaged digitally in transmitted and reflected light. Using the scanning electron microscope, zircons were imaged in cathodoluminescence (CL), whereas titanites were imaged by back-scattered electrons (BSE).

Following the methods of Williams (1998), SHRIMP analysis consisted of excavating a pit about 25 to 35 $\mu \mathrm{m}$ in diameter and about $1 \mu \mathrm{m}$ in depth, using a primary oxygen beam at a current of about $4 \mathrm{nA}$. The magnet cycled through the mass stations 6 times per analysis. Raw data were reduced using Squid 1 (Ludwig, 2001) and plotted using Isoplot 3 (Ludwig, 2003). Instrument fractionation for ${ }^{206} \mathrm{~Pb} /{ }^{238} \mathrm{U}$ ages was corrected using zircon standard R33 (419 \pm 1 Ma; Black and others, 2004) or titanite standard BLR-1 (1047.1 $\pm 0.4 \mathrm{Ma}$; see below). Uranium concentrations are believed to be accurate to \pm 20 percent. U-Pb data are plotted on Tera-Wasserburg concordia plots to visually identify coherent ages groups. Weighted averages of individual ${ }^{206} \mathrm{~Pb} /{ }^{238} \mathrm{U}$ ages were calculated to obtain an age for each sample. For titanite, lower intercept concordia ages were calculated through data that were uncorrected for common $\mathrm{Pb}$, using the Isoplot 3-D linear regression (Ludwig, 2003).

TIMS U-Pb Geochronology of Titanite

Titanite standard BLR-1 was dated by thermal ionization mass spectrometry (TIMS). A number of translucent brown fragments visually free of alteration were picked and half of the fragments abraded for 3 hours to smooth ellipsoids in an alumina-ceramic vortical abrader. Six individual fragments (three abraded, three unabraded) were ultrasonicated in double-distilled acetone, rinsed in high-purity $\mathrm{H}_{2} \mathrm{O}$, spiked and dissolved at $220^{\circ} \mathrm{C}$ for 96 hours in $29 \mathrm{M} \mathrm{HF}$ and $7 \mathrm{M} \mathrm{HNO}_{3}$; samples were subsequently dried, redissolved in $6 \mathrm{M} \mathrm{HCl}$ at $180^{\circ} \mathrm{C}$ for 24 hours and then converted to $1.1 \mathrm{M} \mathrm{HBr}$ for ion exchange chemistry. Details of mass spectrometry and data reduction are stated in the footnotes to table A1.

Five of six fragments yielded essentially equivalent isotope ratios defining a precise inverse variance weighted mean ${ }^{206} \mathrm{~Pb} /{ }^{238} \mathrm{U}$ age of $1047.1 \pm 0.4 \mathrm{Ma}(2 \sigma$, MSWD 0.56) (fig. A1), including tracer calibration uncertainty (Schoene and others, 2006). A sixth fragment exhibits lower isotope ratios and younger ages; in retrospect, this unabraded fragment did have a slightly hackly texture on one surface, which might indicate that it was originally adjacent to a fracture, and subject to a very minor amount of surface-correlated $\mathrm{Pb}$ loss. For the cluster of five equivalent fragments, the slightly elevated MSWD statistics for the weighted mean ${ }^{207} \mathrm{~Pb} /{ }^{235} \mathrm{U}(1048.0 \pm 0.7 \mathrm{Ma} ; 2 \sigma$, MSWD 2.8$)$ and ${ }^{207} \mathrm{~Pb} /{ }^{206} \mathrm{~Pb}(1049.9 \pm 1.3 \mathrm{Ma} ; 2 \sigma$, MSWD 2.9) ages are due to a small dispersion in ${ }^{207} \mathrm{~Pb} /{ }^{235} \mathrm{U}$ ratios. The cluster of data appears slightly discordant, although it lies within the concordia error envelope defined by the decay constant uncertainties of Jaffey and others (1971). This slight degree of discordance $(0.26 \%)$ is consistent with the regular bias manifested by other high quality zircon and xenotime data sets reported by Schoene and others (2006), which was attributed to a small systematic error in one or more of the currently utilized U decay constants (most likely that of ${ }^{235} \mathrm{U}$; see also Mattinson, 2000). For the purposes of its use as a SHRIMP standard, BLR-1 titanite has an apparently uniform ${ }^{206} \mathrm{~Pb} /{ }^{238} \mathrm{U}$ ratio of $0.17636 \pm 0.000067(2 \sigma)$.

\section{Determination of $\mathrm{Pb}, \mathrm{Sr}$, and Nd Initial Isotopic Ratios}

Whole-rock fractions were analyzed for $\mathrm{Pb}, \mathrm{Sr}$, and $\mathrm{Nd}$ isotopes. These splits were spiked with ${ }^{205} \mathrm{~Pb}_{-}{ }^{233} \mathrm{U}_{-}{ }^{236} \mathrm{U}_{-}{ }^{230} \mathrm{Th},{ }^{87} \mathrm{Rb}_{-}{ }^{84} \mathrm{Sr}$, and ${ }^{149} \mathrm{Sm}^{-}{ }^{150} \mathrm{Nd}$-enriched tracers and were digested in PFA-teflon screwcap bombs with $\mathrm{HF}$, and $\mathrm{HNO}_{3}$ for a minimum of 48 hours at approximately $120^{\circ} \mathrm{C}$. Lead was first isolated using anion exchange in $0.5 \mathrm{~N} \mathrm{HBr}$ medium. Uranium and thorium were separated together using anion exchange in $7 \mathrm{~N} \mathrm{HNO}_{3}$ medium. Rubidum, strontium, and a rare-earth-element fraction were isolated using cation exchange in $2.5 \mathrm{~N} \mathrm{HCl}$ medium. Samarium and neodymium were separated from the rare-earth fraction using cation exchange in $0.2 \mathrm{M}$-methyllactic acid. Blanks for the procedure were on the order of 50 $\mathrm{pg}(\mathrm{Pb}), 15 \mathrm{pg}(\mathrm{U}+\mathrm{Th}), 40 \mathrm{pg}(\mathrm{Rb}), 300 \mathrm{pg}(\mathrm{Sr}), 50 \mathrm{pg}(\mathrm{Sm})$, and $300 \mathrm{pg}(\mathrm{Nd})$.

Mass spectrometry for $\mathrm{Pb}$ was performed using either a VG Sector 54 7-collector thermal ionization mass spectrometer or a VG54R single-collector mass spectrometer. Mass fractionation for $\mathrm{Pb}$ during mass spectrometry was monitored by replicate analyses of NIST standard SRM-981. Rubidum, Sr, Sm, and Nd were all analyzed using a VG 54R single-collector mass spectrometer. Rubidum was run using a triple Re filament technique. Strontium was run using a single oxidized Ta filament. Strontium isotopic data were normalized to ${ }^{86} \mathrm{Sr} /{ }^{88} \mathrm{Sr}=0.1194$. Seventeen analyses of the NIST standard SRM-987 run during the course of this study yielded a mean ${ }^{87} \mathrm{Sr} /{ }^{86} \mathrm{Sr}=0.710251 \pm 0.000008\left(2 \sigma_{\mathrm{m}}\right)$. Samarium and $\mathrm{Nd}$ were run using a triple filament technique with a Re ionizing filament and Ta sample filaments. Neodymium isotopic data were normalized to ${ }^{146} \mathrm{Nd} /{ }^{144} \mathrm{Nd}=0.7219$. Eleven analyses of the La Jolla $\mathrm{Nd}$ standard run during the course of this study gave a mean ${ }^{143} \mathrm{Nd} /{ }^{144} \mathrm{Nd}=0.511860 \pm 0.000009\left(2 \sigma_{\mathrm{m}}\right)$. 


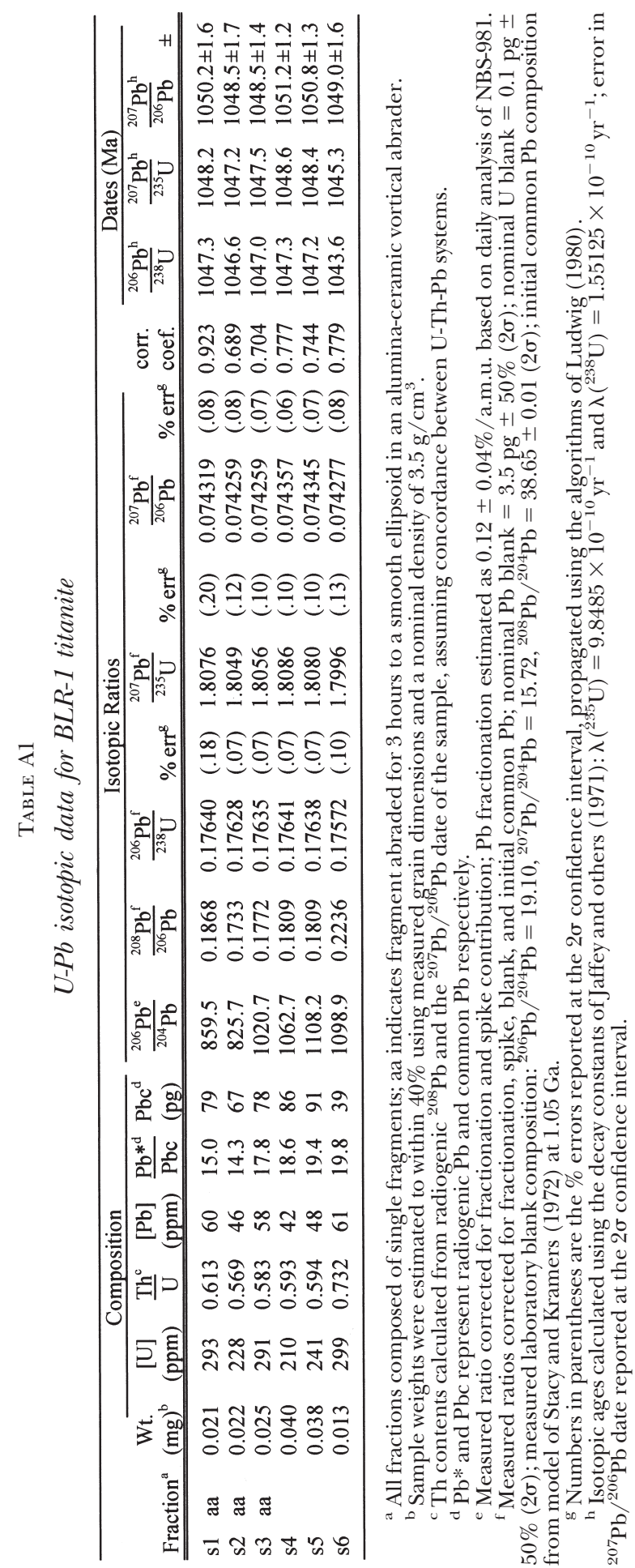




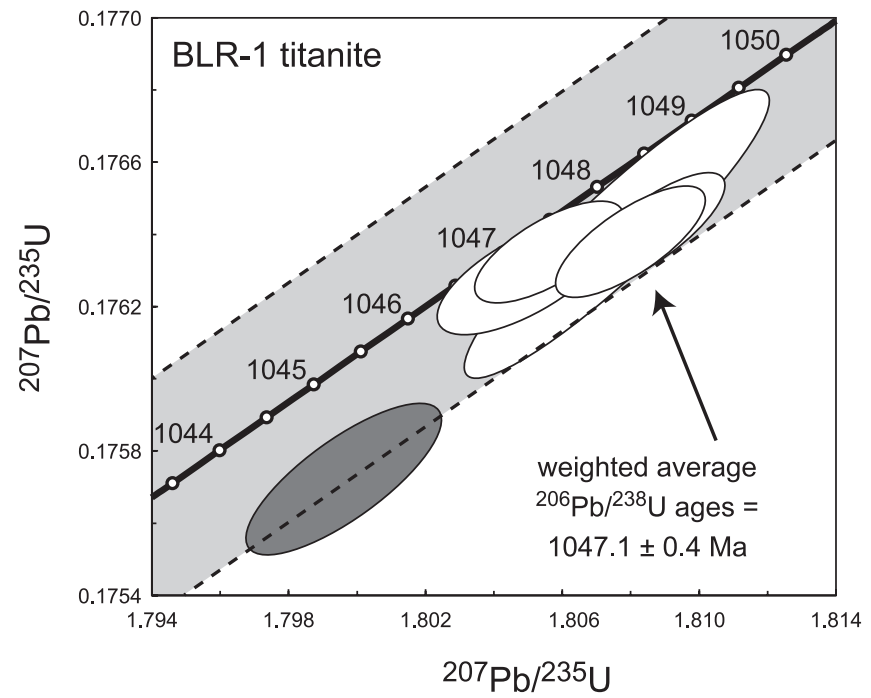

Fig. A1. Concordia plot of TIMS data for titanite SHRIMP standard BLR-1. Shaded gray band represents Concordia including uncertainties in decay constants. Discordant gray-filled error ellipse excluded from age calculation.

Initial isotopic ratios were calculated using ages determined by zircon U-Pb geochronology. This method presumes that the rocks remained closed to isotopic re-equilibration. In some cases, impossible initial Sr ratios were calculated, indicating that the presumption of isotopic closure was not achieved. For this reason, Sr data are shown in tabular form only.

\section{REFERENCES}

Aleinikoff, J. N., Wintsch, R. P., Fanning, C. M., and Dorais, M. J., 2002, U-Pb geochronology of zircon and polygenetic titanite from the Glastonbury Complex, Connecticut, USA: An integrated SEM, EMPA, TIMS, and SHRIMP study: Chemical Geology, v. 188, n. 1-2, p. 125-147.

Ayuso, R. A., and Bevier, M. L., 1991, Regional differences in Pb isotopic compositions of feldspars in plutonic rocks of the northern Appalachian Mountains, U.S.A., and Canada: A geochemical method of terrane correlation: Tectonics, v. 10, p. 191-212.

Barker, F., 1979, Trondhjemite: Definition, environment, and hypothesis of origin, in Barker, F., editor, Trondjhemites, dacites, and related rocks: Amsterdam, Elsevier, p. 1-12.

Barr, S. M., and Hegner, E., 1992, Nd isotopic compositions of felsic igneous rocks in Cape Breton Island, Nova Scotia: Canadian Journal of Earth Sciences, v. 29, p. 650-657.

Barr, S. M., and White, C. E., 1996, Contrasts in late Precambrian-early Paleozoic tectonothermal history between Avalon composite terrane sensu stricto and other possible peri-Gondwanan terranes in southern New Brunswick and Cape Breton Island, Canada, in Nance, R. D., and Thompson, M. D., editors, Avalonian and Related Peri-Gondwanan Terranes of the Circum-North Atlantic: Boulder, Colorado, Geological Society of America Special Paper 304, p. 95-108.

Barr, S. M., White, C. E., Miller, B. V., and van Staal, C. R., 2002, The myth of "Avalonia": Did it constitute a single terrane or several different terranes in the early Paleozoic: Geological Society of America Abstracts with Programs, v. 34, n. 1, p. A28.

Barr, S. M., Davis, D. W., Kamo, S., and White, C. E., 2003, Significance of U-Pb detrital ages in quartzite from peri-Gondwanan terranes, New Brunswick and Nova Scotia, Canada: Precambrian Research, v. 126, p. 123-145.

Bernold, S., 1976, Preliminary bedrock geologic map of the Guilford quadrangle, Connecticut: State Geological and Natural History Survey of Connecticut, Open File Report OF-76-1, scale 1:24,000.

Bevins, R. E., Kokelaar, B. P., and Dunkley, P. N., 1984, Petrology and geochemistry of lower to middle Ordovician igneous rocks in Wales: a volcanic arc to marginal basin transition: Proceedings of the Geologist's Association, 95, p. 337-347.

Black, L. P., Kamo, S. L., Allen, C. M., Davis, D. W., Aleinikoff, J. N., Valley, J. W., Mundil, R., Campbell, I. H., Korsuch, R. J., Williams, I. S., and Foudoulis, C., 2004, Improved ${ }^{206} \mathrm{~Pb} /{ }^{238} \mathrm{U}$ microprobe geochronology by the monitoring of a trace-element-related matrix effect; SHRIMP, ID-TIMS, ELA-ICP-MS and oxygen isotope documentation for a series of zircon standards: Chemical Geology, v. 205, p. 115-140. 
Budahn, J. R., and Wandless G. A., 2002, Instrumental neutron activation by long count: U.S. Geological Survey Open-File Report OF 02-0223, p. X1-X13.

Bull, J. M., and Robinson, P., 1994, Geochemistry of the Fourmile Gneiss, Pelham dome, central Massachusetts: Implications for the tectonic setting of the Bronson Hill magmatic arc: Geological Society of America Abstracts with Programs, 26, n. 3, p. 9.

Carmichael, I. S. E., 1964, The petrology of Thingmuli, a tertiary volcano in eastern Iceland: Journal of Petrology, v. 5, p. 435-460.

DePaolo, D. J., 1981, Neodymium isotopes in the Colorado Front Range and crust-mantle evolution in the Proterozoic: Nature, v. 291, p. 193-196.

Dixon, H. R., and Lundgren, L. W., 1968, Structure of eastern Connecticut, in Zen, E., White, W. S., Hadley, J. B., and Thompson, J. B., Jr., editors, Studies of Appalachian geology, northern and maritime: New York, Wiley Interscience Publishers, p. 219-229.

Dorais, M. J., and Paige, M. L., 2000, Regional geochemical and isotopic variations of northern New England plutons: Implications for magma sources and for Grenville and Avalon basement-terrane boundaries: Geological Society of America Bulletin, v. 112, p. 900-914

Drummond, M. S., Bordelon, M., De Boer, J. Z., Defant, M. J., Bellon, H., and Feigenson, M. D., 1995, Igneous petrogenesis and tectonic setting of plutonic and volcanic rocks of the Cordillera de Talamanca, Costa Rica-Panama, Central American arc: American Journal of Science, v. 295, p. 875-919.

Eusden, J. D., and Barreiro, B., 1988, The timing of peak high-grade metamorphism in central-eastern New England: Maritime Sediments and Atlantic Geology, v. 24, p. 241-255.

Förster, H. J., Tischendorf, G., and Trumbull, R. B., 1997, An evaluation of the Rb vs. (Y $+\mathrm{Nb})$ discrimination diagram to infer tectonic setting of silicic igneous rocks: Lithos, v. 40, p. 261-293.

Foye, W. G., 1949, The geology of eastern Connecticut: State Geological and Natural History Survey of Connecticut Bulletin 74, $100 \mathrm{p}$.

Frost, B. R., Barnes, C. G., Collins, W. J., Arculus, R. J., Ellis, D. J., and Frost, C. D., 2001, A geochemical classification for granitic rocks: Journal of Petrology, v. 42, p. 2033-2048.

Gradstein, F. M., Ogg, J. G., and Smith, A. G., 2004, A geologic time scale 2004: Cambridge, Cambridge University Press, $384 \mathrm{p}$

Harper, D. A., Mac Niocaill, C., and Williams, S. H., 1996, The palaeogeography of Early Ordovician Iapetus terranes: An integration of faunal and palaeomagnetic constraints: Palaeogeography, Palaeoclimatology, Palaeoecology, v. 121, p. 297-312.

Hibbard, J. P., van Staal, C. R., Rankin, D. R., and Williams, H., 2006, Lithotectonic map of the Appalachian Orogen, Canada-United States of America: Geological Survey of Canada, Map 2096A, scale 1:1,500,000.

Hoskin, P. W. O., and Schaltegger, U., 2003, The composition of zircon and igneous and metamorphic petrogenesis, in Hanchar, J. M., and Hoskin, P. W. O., editors, Zircon: Washington, D. C., Mineralogical Society of America, Reviews in Mineralogy and Geochemistry, v. 53, p. 27-62.

Irvine, T. N., and Baragar, W. R. A., 1971, A guide to the chemical classification of the common volcanic rocks: Canadian Journal of Earth Science, v. 8, p. 523-548.

Jaffey, A. H., Flynn, K. F., Glendenin, L. E., Bentley, W. C., and Essling, A. M., 1971, Precision measurement of half-lives and specific activities of ${ }^{235} \mathrm{U}$ and ${ }^{238} \mathrm{U}$ : Physical Review, v. C4, p. 1889-1906.

Karabinos, P., Samson, S. D., Hepburn, J. C., and Stoll, H. M., 1998, Taconian orogeny in the New England Appalachians: Collision between Laurentia and the Shelburne Falls arc: Geology, v. 26, p. 215-218

Kerr, A., 1997, Space-time composition relationships among Appalachian-cycle plutonic suites in Newfoundland, in Sinha, A. K., Whalen, J. B., and Hogan, J. P., editors, The Nature of Magmatism in the Appalachian Orogen: Boulder, Colorado, Geological Society of America Memoir 191, p. 193-220.

Kerr, A., Jenner, G. A., and Fryer, B. J., 1995, Sm-Nd isotopic geochemistry of Precambrian to Paleozoic granitoid suites and deep-crustal structure of the southeast margin of the Newfoundland Appalachians: Canadian Journal of Earth Sciences, v. 32, p. 224-245.

Kim, J., and Jacobi, R. D., 2002, Boninites; characteristics and tectonic constraints, northeastern Appalachians: Physics and Chemistry of the Earth, v. 27, p. 109-147.

Lathrop, A. S., Blum, J. D., and Chamberlain, C. P., 1996, Nd, Sr, and O isotopic study of the petrogenesis of two syntectonic members of the New Hampshire Plutonic Series: Contributions to Mineralogy and Petrology, v. 124, p. 126-138.

Le Maitre, R. W., Bateman, P., Dudek, A., Keller, J., Lameyre, J., Le Bas, M. J., Sabine, P. A., Schimd, R., Sørensen, H., Streckeisen, A., Woolley, A. R., and Zanettin, B., 1989, A classification of igneous rocks and a glossary of terms: Oxford, Blackwell, $193 \mathrm{p}$.

Lin, S., van Staal, C. R., and Dube, B., 1994, Promontory-promontory collision in the Canadian Appalachians: Geology, v. 22, p. 897-900.

Loewy, S. L., Connelly, J. N., and Dalziel, I. W. D., 2004, An orphaned basement block: The ArequipaAntofalla Basement of the central Andean margin of South America: Geological Socioety of America Bulletin, v. 116, p. 171-187.

Ludwig, K. R., 1980, Calculation of uncertainties of U-Pb isotope data: Earth and Planetary Science Letters, v. 46 , p. 212-220.

2001, Squid, version 1.02, A user's manual: Berkeley Geochronology Center Special Publication, No. 2, $21 \mathrm{p}$.

2003, Isoplot/Ex version 3.00, A geochronological toolkit for Mircosoft Excel: Berkeley Geochronology Center Special Publication, No. 4, 73 p.

Lundgren, L., Jr., 1963, The bedrock geology of the Deep River quadrangle: State Geological and Natural History Survey of Connecticut Quadrangle Report n. 13, 40 p.

1964, The bedrock geology of the Essex quadrangle: State Geological and Natural History Survey of Connecticut Quadrangle Report n. 15, 36 p. 
1979, The bedrock geology of the Haddam quadrangle: State Geological and Natural History Survey of Connecticut Quadrangle Report n. 37, 44 p.

Lundgren, L., Jr., and Thurrell, R. F., 1973, Bedrock geology of the Clinton quadrangle: State Geological and Natural History Survey of Connecticut Quadrangle Report 29, 22 p.

Lyons, J. B., Boudette, E. L., and Aleinikoff, J. N., 1982, The Avalonian and Gander zones in central eastern new England in St-Julien, P., and Béland, J., editors, Major Structural zones and faults of the Northern Appalachians: Geological Association of Canada Special Paper 24, p. 43-66.

Mac Niocaill, C., van der Pluijm, B. A., and Van der Voo, R., 1997, Ordovician paleogeography and the evolution of the Iapetus ocean: Geology, v. 25, p. 159-162.

Mattinson, J. M., 2000, Revising the "gold standard" - the uranium decay constants of Jaffey and others, 1971: Eos Trans, AGU, Spring Meeting Supplement, Abstract V61A-02.

Mikami, H. M., and Digman, R. E., 1957, The bedrock geology of the Guilford 15-minute quadrangle and a portion of the New Haven quadrangle: State Geological and Natural History Survey of Connecticut, Bulletin 86, 99 p.

Moench, R. H., and Aleinikoff, J. N., 2003, Stratigraphy, geochronology. and accretionary terrane settings of two Bronson Hill arc sequences, northern New England: Physics and Chemistry of the Earth, v. 28, p. 113-160.

Nance, R. D., and Murphy, J. B., 1996, Basement isotopic signatures and Neoproterozoic paleogeography of Avalonian-Cadomian and related terranes in the circum-North Atlantic, in Nance, R. D., and Thompson, M. D., editors, Avalonian and Related Peri-Gondwanan Terranes of the Circum-North Atlantic: Boulder, Colorado, Geological Society of America Special Paper 304, p. 333-346.

North American Commission on Stratigraphic Nomenclature (NACSN) (1983), North American stratigraphic code: American Association of Petroleum Geologists Bulletin, v. 67, p. 841-875.

O'Brien, S. J., O'Brien, B. H., Dunning, G. R., and Tucker, R. D., 1996, Late Neoproterozoic Avalonian and related peri-Gondwanan rocks of the Newfoundland Appalachians, in Nance, R. D., and Thompson, M. D., editors, Avalonian and Related Peri-Gondwanan Terranes of the Circum-North Atlantic: Boulder, Colorado, Geological Society of America Special Paper 304, p. 9-28.

Ortega-Gutierrez, F., Ruiz, J., and Centeno-Garcia, E., 1995, Oaxaquuia, a Proterozoic microcontinent accreted to North America during the late Paleozoic: Geology, v. 23, p. 1127-1130.

Osberg, P. H., 1978, Synthesis of the geology of the Northern Appalachians, U.S.A.: Geological Survey of Canada Paper 78-13, p. 137-147.

Pe-Piper, G, and Piper, D. J. W., 1998, Geochemical evolution of Devonian-Carboniferous igneous rocks of the Magdalen basin, Eastern Canada: $\mathrm{Pb}$ - and $\mathrm{Nd}$-isotope evidence for mantle and lower crustal sources: Canadian Journal of Earth Sciences, v. 35, p. 201-221

Pearce, J. S., 1983, Role of the sub-continental lithosphere in magma genesis at active continental margins, in Hawksworth, C. J., and Norry, M. J., editors, Continental basalts and mantle xenolioths: Nantwich, Cheshire, England, Shiva, p. 230-249.

Pearce, J. S., Harris, N. B. W., and Tindle, A. G., 1984, Trace element discrimination diagrams for the tectonic interpretation of granitic rocks: Journal of Petrology, v. 25, p. 956-983.

Percival, J. G., 1842, Report on the geology of the of the state of Connecticut: New Haven, Osborn and Baldwin, 495 p., map.

Reusch, D. N., van Staal, C. R., and McNicoll, V. J., 2004, Detrital zircons and Ganderia's southern margin, coastal Maine: Geological Society of America Abstracts with Programs, v. 36, n. 2, p. 129

Rice, W. N., and Gregory, H. E., 1906, Manual of the geology of Connecticut: State Geological and Natural History Survey of Connecticut, Bulletin 6, 273 p.

Rodgers, J., 1985, Bedrock geological map of Connecticut: Hartford, Connecticut Geological and Natural History Survey, Department of Environmental Protection, scale 1:125,000.

Rodgers, J., Gates, R. M., and Rosenfeld, J. L., 1959, Explanatory Text for Preliminary Geological Map of Connecticut, 1956: State Geological and Natural History Survey of Connecticut Bulletin 84, 64 p.

Samson, S. D., Barr, S. M., and White, C. E., 2000, Nd isotopic characteristics of terranes within the Avalon Zone, southern New Brunswick: Canadian Journal of Earth Sciences, v. 37, p. 1039-1052.

Schoene, B., Crowley, J. C., Condon, D. J., Schmitz, M. D., and Bowring, S. A., 2006, Reassessing the uranium decay constants for geochronology using ID-TIMS U-Pb data: Geochimica et Cosmochimica Acta, v. 70, p. $426-445$.

Sevigny, J. H., and Hanson, G. N., 1993, Orogenic evolution of the New England Appalachians of southwestern Connecticut: Geological Society of America Bulletin, v. 105, p. 1591-1605.

1995, Late-Taconian and pre-Acadian history of the New England Appalachians of southwestern Connecticut: Geological Society of America Bulletin, v. 107, p. 487-498.

Smith, I. E. M., Brothers, R. N., Muiruri, R. G., and Browne, P. R. L., 1988, The geochemistry of rock and water samples from Curtis Island volcano, Kermadec group, southwest Pacific: Journal of Volcanology and Geothermal Research, v. 34, p. 233-240.

Spear, F. S., and Harrison, T. M., 1989, Geochronologic studies in central New England; I, Evidence for pre-Acadian metamorphism in eastern Vermont: Geology, v. 18, p. 181-184.

Stacey, J. S., and Kramers, J. D., 1975, Approximation of terrestrial Pb isotope composition by a two-stage model: Earth and Planetary Science Letters, v. 26, p. 207-222.

Steiger, R. H., and Jäger, E., 1977, Subcommission on geochronology, convention on the use of decay constants in geo- and cosmochronology: Earth and Planetary Science Letters, v. 36, p. 359-362.

Taggart, J. E., and Siems, D. F., 2002, Major element analysis by wavelength dispersive X-ray fluorescence spectrometry: U.S. Geological Survey Open-File Report OF-02-0223, p. T1-T9.

Thompson, M. D., and Bowring, S. A., 2000, Age of the Squantum "tillite," Boston Basin, Massachusetts: U-Pb zircon constraints on terminal Neoproterozoic glaciation: American Journal of Science, v. 300, p. 630 655 . 
Tohver, E., Bettencourt, J. S., Tosdal, R., Mezger, K., Leite, W. B., and Payolla, B. L., 2004, Terrane transfer during the Grenville orogeny: tracing the Amazonian ancestry of southern Appalachian basement through Pb abd Nd isotopes: Earth and Planetary Science Letters, v. 228, p. 161-176.

Tomascak, P. B., Brown, M., Solar, G. S., Becker, H. J., Centorbi, T. L., and Tian, J., 2005, Source contributions to Devonian granite magmatism near the Laurentian border, New Hampshire and Western Maine, USA: Lithos, v. 80, p. 75-99.

Tremblay, A., and Pinet, N., 2005, Diachronous supracrustal extension in an intraplate setting and the origin of the Connecticut Valley-Gaspe and Merrimack Troughs, northern Appalachians: Geological Magazine, v. 142, p. 7-22.

Tucker, R. D., and Robinson, P., 1990, Age and setting of the Bronson Hill magmatic arc: A re-evaluation based on U-Pb zircon ages in southern New England: Geological Society of America Bulletin, v. 102, p. 1404-1419.

Tucker, R. D., Osberg, P. H., and Berry, H. N., IV, 2001, The geology of a part of Acadia and the nature of the Acadian orogeny across central and eastern Maine: American Journal of Science, v. 301, p. 205-260.

Valverde-Vaquero, P., van Staal, C. R., McNicoll, V., and Dunning, G. R., 2006, Mid-Late Ordovician magmatism and metamorphism along the Gander margin in central Newfoundland: Journal of the Geological Society, v. 163, p. 347-362.

van Staal, C. R., 1994, Brunswick subduction complex in the Canadian Appalachians: record of Late Ordovician to Silurian collision between Laurentia and the Gander margin of Avalon: Tectonics, v. 13, p. 946-962.

van Staal, C. R., Sullivan, R. W., and Whalen, J. B., 1996, Provenance and tectonic origin of the Gander Zone in the Caledonian/Appalachian orogen: Implications for the origin and assembly of Avalon, in Nance, R. D., and Thompson, M. D., editors, Avalonian and Related Peri-Gondwanan Terranes of the Circum-North Atlantic: Boulder, Colorado, Geological Society of America Special Paper 304, p. 347367.

van Staal, C. R., Dewey, J. F., Mac Niocaill, C., and McKerrow, W. S., 1998, The Cambrian-Silurian tectonic evolution of the northern Appalachians and British Caledonides: History of a complex, west and southwest Pacific-type segment of Iapetus, in Blundell, D. J., and Scott, A. C., editors, Lyell: the Past is the Key to the Present: London, Geological Society Special Publication, v. 143, p. 199-242.

van Staal, C. R., McNicoll, V. J., Valverde-Vaquero, P., Barr, S. M., Fyffe, L. R., and Reusch, D. N., 2004, Ganderia, Avalonia, and the Salinic and Acadian orogenies: Geological Society of America Abstracts with Programs, v. 36, n. 2, p. 128.

Walsh, G. J., Aleinikoff, J. N., and Wintsch, R. P., 2007, Origin of the Lyme Dome and implications for the timing of multiple Alleghanian anatectic and intrusive events in Southern Connecticut: American Journal of Science, v. 307, p. 168-215.

Webster, J. R., and Wintsch, R. P., 1987, Petrochemistry and origin of the Killingworth dome rocks, Bronson Hill anticlinorium, south-central Connecticut: Geological Society of America Bulletin, v. 98, p. 465474.

Whalen, J. B., Fyffe, L. R., Longstaffe, F. J., and Jenner, G. A., 1996, The position and nature of the Gander-Avalon boundary, southern New Brunswick, based on geochemical and isotopic data from granitoid rocks: Canadian Journal of Earth Sciences, v. 33, p. 129-139.

Whalen, J. B., van Staal, C. R., Longstaffe, F. J., Gariepy, C., and Jenner, G. A., 1997, Insights into tectonostratigraphic zone identification in southwestern Newfoundland based on isotopic $(\mathrm{Nd}, \mathrm{O}, \mathrm{Pb})$ and geochemical data: Atlantic Geology, v. 33, p. 231-241.

Whalen, J. B., Rogers, N., van Staal, C. R., Longstaffe, F. J., Jenner, G. A., and Winchester, J. A., 1998, Geochemical and isotopic $(\mathrm{Nd}, \mathrm{O})$ data from Ordovician felsic plutonic and volcanic rocks of the Miramichi Highlands: petrogenetic and metallogenetic implications for the Bathurst Mining Camp: Canadian Journal of Earth Sciences, v. 35, p. 237-252.

Williams, H., 1978, Tectonic lithofacies map of the Appalachian orogen: Newfoundland, Canada, St. Johns, Memorial University of Newfoundland Map No. 1, scale 1:1,000,000.

Williams, H., Coleman-Saad, S. P., and Swinden, H. S., 1988, Tectonic-stratigraphic subdivisions of central Newfoundland: Current Research, Part B, Geological Survey of Canada Paper 88-1B, p. 91-98.

Williams, I. S., 1998, Chapter 1, U-Th-Pb geochronology by ion microprobe, in McKibben, M. A., Shanks, W. C., III, and Ridley, W. I., editors, Applications of microanalytical techniques to understanding mineralizing processes: Reviews of Economic Geology, v. 7, p. 1-35.

Winter, J. D., 2001, An Introduction to Igneous and Metamorphic Petrology: Upper Saddle River, New Jersey, Prentice Hall, 697 p.

Wintsch, R. P., 1994, Bedrock geologic map of the Deep River area, Connecticut with explanatory text: State Geological and Natural History Survey of Connecticut, Open File Report OF-94-1, scale 1:24,000.

Wintsch, R. P., Webster, J. R., Bernitz, J. A., and Fout, J. S., 1990, Geochemical and geological criteria for the discrimination of high grade gneisses of intrusive and extrusive origin, southern Connecticut, in Socci, A. D., Skehan, J. W., and Smith, G. W., editors, Geology of the composite Avalon terrane of southern New England: Geological Society of America Special Paper, v. 245, p. 187-208.

Wintsch, R. P., Sutter, J. F., Kunk, M. J., Aleinikoff, J. N., and Dorais, M. J., 1992, Contrasting P-T-t paths: Thermochronologic evidence for a Late Paleozoic final assembly of the Avalon composite terrane in the New England Appalachians: Tectonics, v. 11, n. 3, p. 672-689.

Wintsch, R. P., Sutter, J. F., Kunk, M. J., Aleinikoff, J. N., and Boyd, J. L., 1993, Alleghanian assembly of Proterozoic and Paleozoic lithotectonic terranes in south-central New England: New constraints from geochronology and petrology, in Cheney, J. T., and Hepburn, J. C., editors, Field trip guidebook for the northeastern United States: Geological Society of America Annual Meeting, v. 1, p. H1-H30. 
Wintsch, R. P., Kunk, M. J., Boyd, J. L., and Aleinikoff, J. N., 2003, P-T-t paths and differential Alleghanian loading and uplift of the Bronson Hill terrane, south central New England: American Journal of Science, v. 303, p. 410-446.

Wintsch, R. P., Aleinikoff, J. N., Webster, J. R., and Unruh, D. M., 2005, The Killingworth Complex: A middle and late Paleozoic magmatic and structural dome: Guidebook for Field Trips in Connecticut, State Geological and Natural History Survey of Connecticut, Guidebook No. 8, p. 305-324.

Wintsch, R. P., Aleinikoff, J. N., Walsh, G. J., Bothner, W. A., and Hussey, A. M., II, 2007, Provenance and metamorphic implications of zircon and monazite U-Pb ages of rocks of the Merrimack and PutnamNashoba terranes, eastern New England: American Journal of Science, v. 307, p. 119-167.

Zagorevski, A., Rogers, N., van Staal, C. R., McNicoll, V., Lissenberg, C. J., and Valverde-Vaquero, P., 2006, Lower to Middle Ordovician evolution of peri-Laurentian arc and backarc complexes in Iapetus: Constraints from Annieopsquotch accretionary tract, Newfoundland: Geological Society of America Bulletin, v. 118, p. 324-342.

Zartman, R. E., and Haines, S. M., 1988, The plumbotectonic model for Pb isotopic systematics among major terrestrial reservoirs-A case for bi-directional transport: Geochimica et Cosmochimica Acta, v. 52, p. 1327-1339. 